\title{
Integrative taxonomy resuscitates two species in the Lasioglossum villosulum complex (Kirby, 1802) (Hymenoptera: Apoidea: Halictidae)
}

\author{
Alain PAULY ${ }^{1, *}$, Grégoire NOËL ${ }^{2}$, Gontran SONET ${ }^{3}$, \\ David G. NOTTON ${ }^{4} \&$ Jean-Luc BOEVÉ ${ }^{5}$ \\ ${ }^{1,3,5}$ Royal Belgian Institute of Natural Sciences, O.D. Taxonomy and Phylogeny \& JEMU, \\ rue Vautier 29, B-1000 Brussels, Belgium. \\ ${ }^{2}$ Functional and Evolutionary Entomology, University of Liège - Gembloux Agro-Bio Tech, \\ Passage des Déportés 2, B-5030 Gembloux, Belgium. \\ ${ }^{4}$ Department of Life Sciences, Insects Division, Darwin Centre - Room 315, \\ The Natural History Museum, Cromwell Road, London, SW7 5BD, United Kingdom. \\ *Corresponding author: apauly@naturalsciences.be; alain.pauly54@gmail.com \\ 2Email: gregoire.noel@uliege.be; gregoirenoel@hotmail.com \\ 32Email: gsonet@naturalsciences.be \\ ${ }^{4}$ Email: d.notton@nhm.ac.uk \\ ${ }^{5}$ Email: jboeve@naturalsciences.be \\ ${ }^{1}$ urn:lsid:zoobank.org:author:3953442F-F55E-45C6-BD0E-12C0E19F34FF \\ ${ }^{2}$ urn:1sid:zoobank.org:author:886A4F27-E95B-4870-9B9F-02586DF75D4C \\ ${ }^{3}$ urn:lsid:zoobank.org:author:BA7353F8-5296-4968-9D2D-D474EF8FCEB6 \\ ${ }^{4}$ urn:1sid:zoobank.org:author:2E452EF2-703C-47C0-8432-6AB9C05AC06A \\ ${ }^{5}$ urn:lsid:zoobank.org:author:23C76CDF-A462-420F-8391-18DA44ADF086
}

\begin{abstract}
Morphological and allozyme analyses suggested the occurrence of a pseudocryptic species in the Lasioglossum villosulum (Kirby, 1802) species complex (Hymenoptera: Halictidae). We analysed the morphology of more than 1500 specimens and the DNA barcode fragment of the cytochrome $c$ oxidase subunit I (COI) of 102 specimens of this species complex from several Palaearctic countries. Our phylogenetic tree reconstructions, based on maximum likelihood and Bayesian inference revealed one clade corresponding to all specimens morphologically identified as Lasioglossum medinai (Vachal, 1895) and one divergent specimen morphologically identified as Lasioglossum berberum (Benoist, 1941). The other specimens, morphologically identified as L. villosulum, aggregated into at least three other lineages in our phylogenetic trees. The tree-based species delineations methods based on the Generalized Mixed Yule Coalescent (GMYC) model and the Bayesian Poisson Tree Process (bPTP) identified five to ten candidate species within the L. villosulum species complex, with $L$. medinai and $L$. berberum consistently recognized as separated from all other candidate species. Diagnostic morphological differences were found among L. medinai, L. berberum and the remaining specimens identified as $L$. villosulum. No diagnostic morphological differences were found to distinguish the different phylogenetic candidate species or lineages found within L. villosulum and L. medinai. Thus,
\end{abstract}


both genetic and morphological approaches support the existence of L. medinai and L. berberum as distinct species from L. villosulum.

Keywords. Bees, Palaearctic, COI, phylogeny, morphology, integrative taxonomy, cryptic species.

Pauly A., Noël G., Sonet G., Notton D.G. \& Boevé J.-L. 2019. Integrative taxonomy resuscitates two species in the Lasioglossum villosulum complex (Kirby, 1802) (Hymenoptera: Apoidea: Halictidae). European Journal of Taxonomy 541:1-43. https://doi.org/10.5852/ejt.2019.541

\section{Introduction}

Integrative taxonomy is efficient in classifying pseudocryptic species, that is, species recognizable by a few apparent, subtle, morphological criteria once their existence is revealed by other methods (Padial et al. 2010; Lajus et al. 2015; Kress et al. 2015; Struck et al. 2017). DNA barcodes combined with morphological, ecological, and geographical data are powerful to detect cryptic species, to clarify species boundaries, and to estimate bee species diversity (Pauly et al. 2015; Schmidt et al. 2015; Bossert et al. 2016; Gonzales-Vaquero et al. 2016; Gibbs 2018; Landaverde-González et al. 2017; Praz et al. 2019; Ferrari 2019). Integrative taxonomy can also contribute to synonymize species (e.g. GonzálezVaquero \& Roig-Alsina 2019).

The Lasioglossum villosulum (Kirby, 1802) species complex is a highly variable group of halictid bees, widespread throughout the Palaearctic (Fig. 1). The nominal subspecies (Fig. 2A, B) is widely distributed from the Azores to Mongolia, from the Canary Islands to Egypt, and north to Finland. The subspecies trichopse (Strand, 1914) occurs from Japan to Manchuria, Taiwan and Malaysia. The subspecies arabicum Ebmer, 2008 (Fig. 2E, F) is endemic to the Arabian Peninsula (Ebmer 1988, 2008). The biology of $L$. villosulum was studied in detail by Plateaux-Quénu \& Plateaux (1981, 1985, 1986, 1987, 1993), Plateaux-Quénu et al. (1987), and Plateaux-Quénu (1993). These authors report the presence of larger females inhabiting the south of France (Fig. 2C, D). On the basis of an electrophoretic analysis

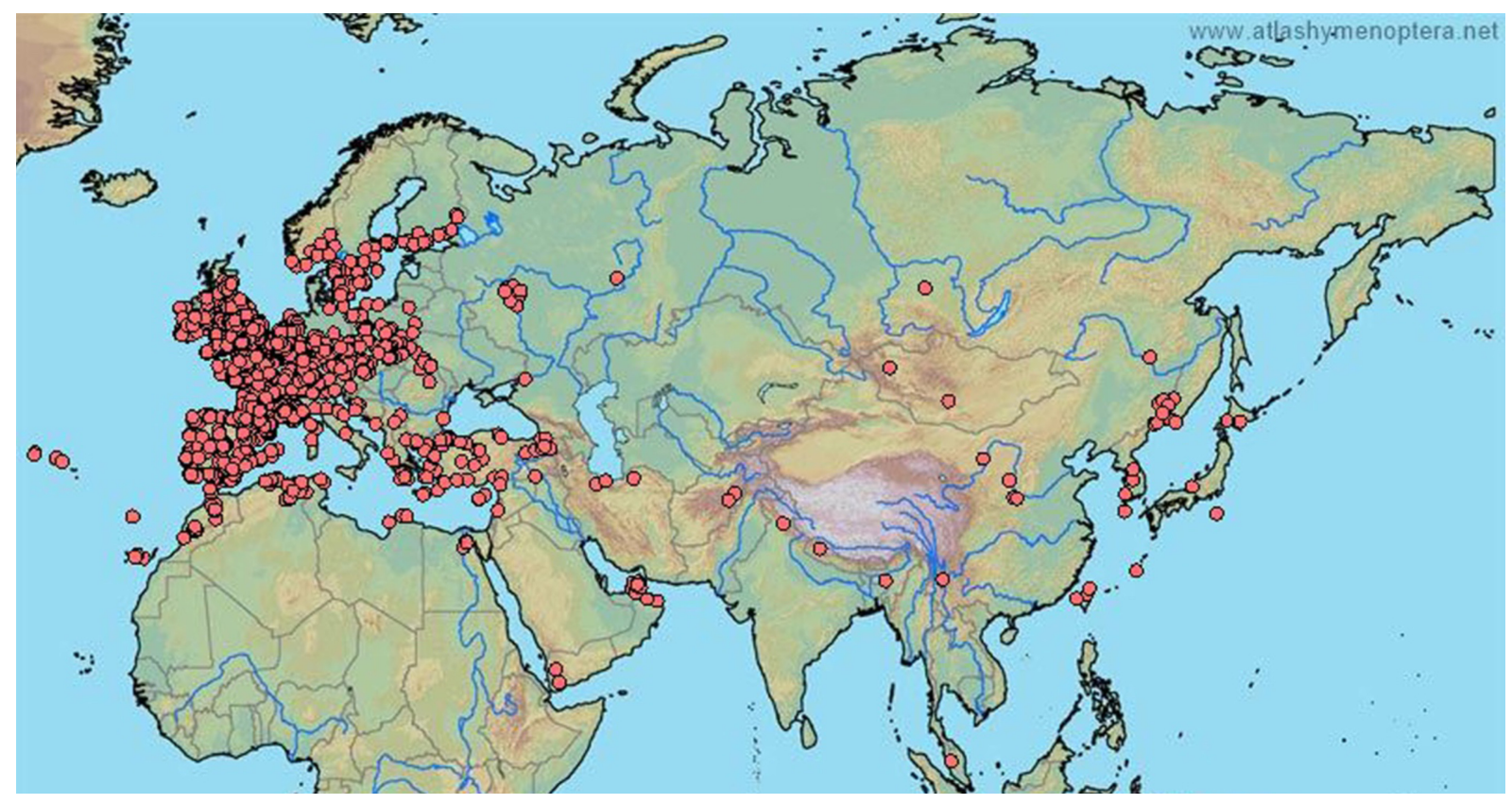

Fig. 1. Distribution of Lasioglossum villosulum (Kirby, 1802) throughout the Palaearctic and Oriental Regions. 


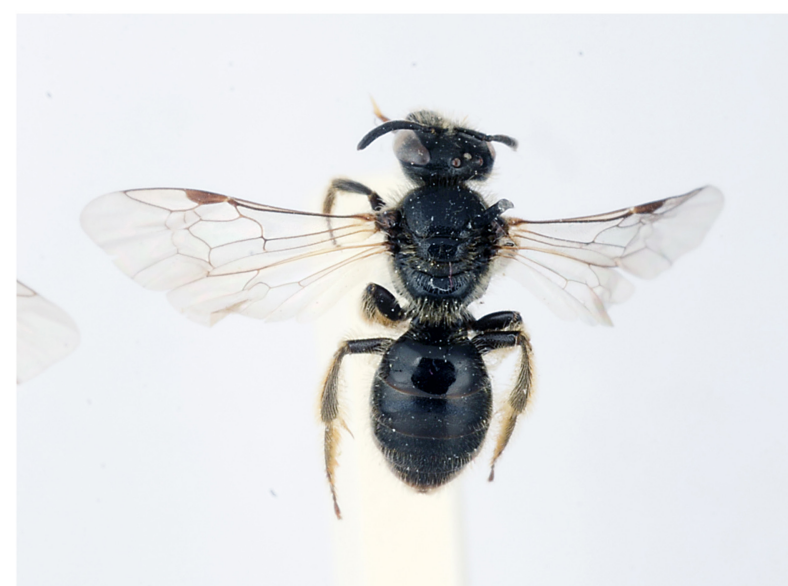

A

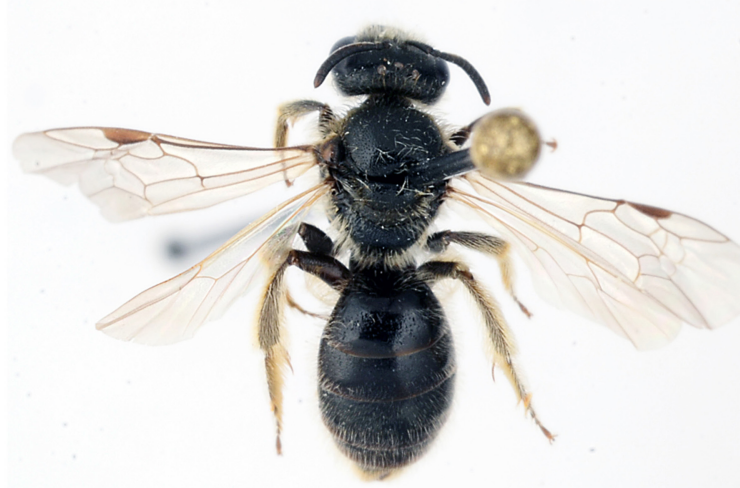

C

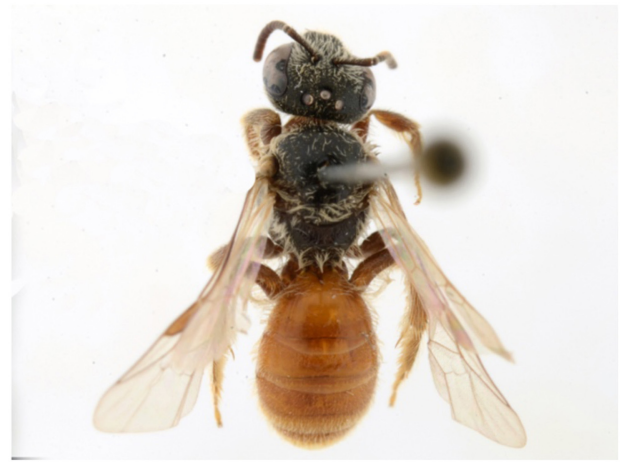

$E$

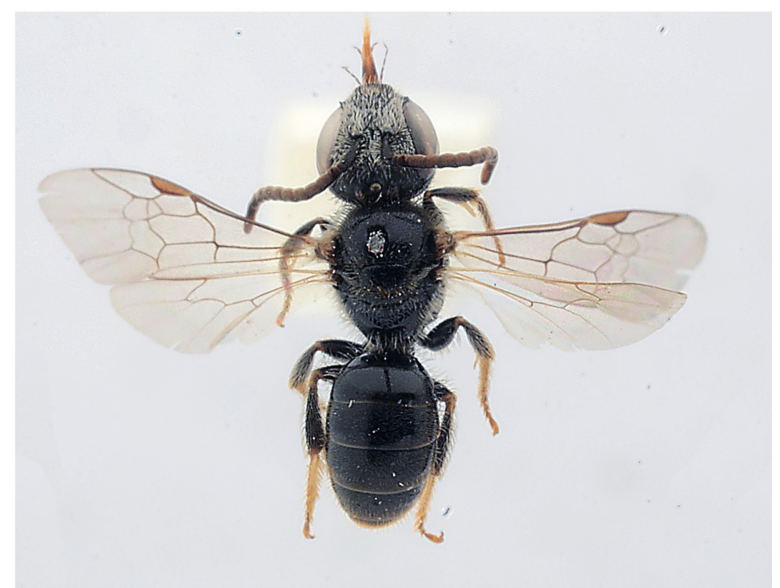

B

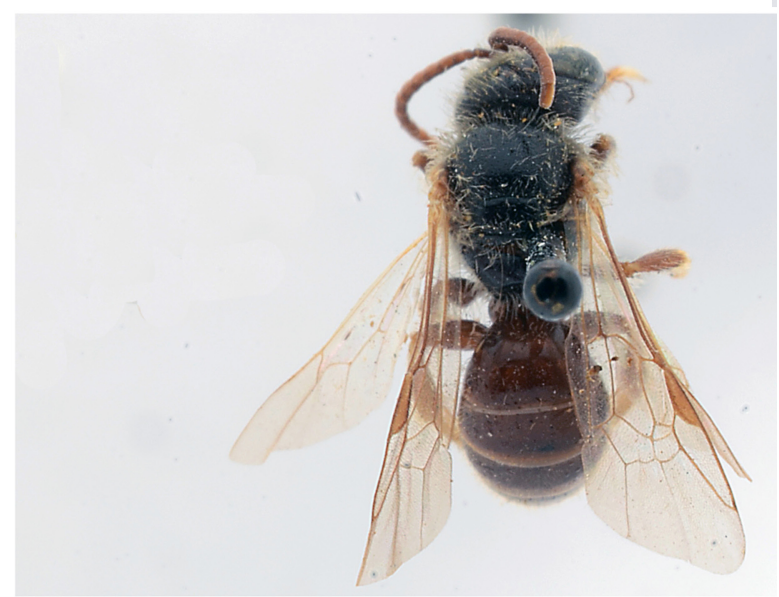

D

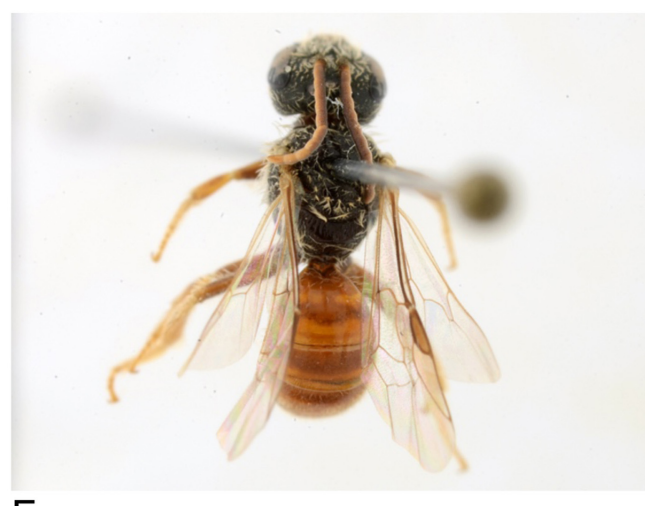

$\mathrm{F}$

Fig. 2. Colouration and relative size of the species and subspecies. A-B. Lasioglossum villosulum (Kirby, 1802), $q$ and $\hat{\partial}$. C-D. L. medinai (Vachal, 1895), $q$ and $\hat{\sigma}$ (holotype). E-F. L. villosulum arabicum Ebmer, 2008, $q$ and $\hat{\partial}$. 
of allozymes, Packer et al. (1999) conclude that these unusually large individuals belong to a new species, but without naming it, and they write: "a formal description of the new species will be presented elsewhere pending additional surveys of museum collections from a wider range of localities and detailed examination of male specimens", but their description was never published. As in other specific complex, Andrena bicolor (Praz et al. 2019) or Bombus lucorum (Bossert et al. 2016), combination of morphological character and genetic analysis of $L$. villosulum could also reveal distinctive species.

The objective of this study is to analyse the morphology and a DNA barcode fragment of the cytochrome $c$ oxidase subunit I (COI) gene of specimens previously identified as $L$. villosulum from various localities from the Palaearctic, with a focus on Europe and the Mediterranean Basin, and to evaluate if larger females collected from the south of France, Israel and Spain belong to a separate species or not. If our results show the existence of a hitherto undescribed species, our aim is, either to resurrect a name among the eight synonyms of L. villosulum listed by Ebmer (1988), or to give a new name to this species.

\section{Material and methods}

\section{Repositories}

The morphological analysis is based on the examination of specimens of the Lasioglossum villosulum complex preserved in the following institutes as well as the private collections mentioned in the acknowledgements:

\begin{tabular}{|c|c|c|}
\hline AMNH & $=$ & American Museum of Natural History, New York, USA \\
\hline GABT & $=$ & Gembloux Agro-Bio Tech, Gembloux, Belgium \\
\hline HUJ & $=$ & Hebrew University of Jerusalem, Rehovot, Israel \\
\hline INRA & $=$ & National Institute of Agronomic Research, Avignon, France \\
\hline MNCN & $=$ & Museo Nacional de Ciencias Naturales, Madrid, Spain \\
\hline MNHN & $=$ & Museum national d'Histoire naturelle, Paris, France \\
\hline MNHUB & $=$ & Museum für Naturkunde an der Humboldt Universität, Berlin, Germany \\
\hline NHMUK & $=$ & Natural History Museum, London, UK, formerly the British Museum (Natural History) \\
\hline RBINS & $=$ & Royal Belgian Institute of Natural Sciences, Brussels, Belgium \\
\hline SDEI & $=$ & Senckenberg Deutsches Entomologisches Institut, Müncheberg, Germany \\
\hline SMF & $=$ & Senckenberg Museum, Frankfurt am Main, Germany \\
\hline
\end{tabular}

\section{Specimens examined}

We re-examined all the types necessary to establish the oldest name of the pseudocryptic species as L. medinai (Vachal, 1895), the oldest synonym from southern Europe with a description corresponding potentially to the unusually large pseudocryptic species. Ebmer (1988) has examined all the types and we follow him for synonymy where we did not examine the types.

NHMUK specimens were assigned unique specimen numbers. Specimen data and images for NHMUK specimens were recorded on the NHMUK database and are publically available through the NHMUK Data Portal (Natural History Museum 2014).

For DNA analysis, we collected 22 female specimens (Table 1) of Lasioglossum villosulum including larger specimens of the presumed new species and representing the widest possible distribution coverage (i.e., representing the maximum number of countries).

\section{DNA extraction}

We used the NucleoSpin ${ }^{\circledR}$ Tissue Kit (Macherey-Nagel, Germany) to extract genomic DNA, following the manufacturer's protocol but eluting the DNA in $80 \mu 1$ elution buffer. If possible, one middle leg per specimen was chosen to prepare samples, and the rest of the specimen was preserved as voucher. 
Table 1. Information of sequenced specimens used in the present study.

\begin{tabular}{|c|c|c|c|c|c|c|}
\hline Code & Species & Locality & Date & Leg. & Primers (F/R) & GenBank \\
\hline AP222 & $\begin{array}{l}\text { Lasioglossum } \\
\text { bluethgeni } \\
\text { Ebmer, } 1971\end{array}$ & Greece, Pieria, Mt Olympus & 2013 & leg. Minachilis & BarbeeF/MtD9 & MK388879 \\
\hline AP231 & $\begin{array}{l}\text { Lasioglossum } \\
\text { villosulum } \\
\text { (Kirby, 1802) }\end{array}$ & France, Rhône, St Jean d'Ardières & 2012 & leg. C.B. Olémé & LCO1490/HCO2198 & MK388880 \\
\hline AP232 & $\begin{array}{l}\text { Lasioglossum } \\
\text { villosulum }\end{array}$ & France, Charente Maritime, Saintes & 2012 & leg. N. Sérès & LCO1490/HCO2198 & MK388881 \\
\hline AP233 & $\begin{array}{l}\text { Lasioglossum } \\
\text { villosulum }\end{array}$ & France, Allier, Commentry & 2013 & leg. E. Van de Pitte & LCO1490/HCO2198 & MK388882 \\
\hline AP234 & $\begin{array}{l}\text { Lasioglossum } \\
\text { villosulum }\end{array}$ & France, Orne, Sées & 2011 & leg. D. Paris & LCO1490/HCO2198 & MK388883 \\
\hline AP235 & $\begin{array}{l}\text { Lasioglossum } \\
\text { villosulum }\end{array}$ & France, Rhône, Lyon & 2013 & leg. F. Vyghen & LCO1490/HCO2198 & MK388884 \\
\hline AP236 & $\begin{array}{l}\text { Lasioglossum } \\
\text { villosulum }\end{array}$ & Spain, Almeria, Almerimar & 2014 & leg. A. Pauly & BarbeeF/MtD9 & MK388885 \\
\hline AP237 & $\begin{array}{l}\text { Lasioglossum } \\
\text { villosulum }\end{array}$ & Belgium, Brussels, Angleur & 2014 & leg. A. Pauly & LCO1490/HCO2198 & MK388886 \\
\hline AP238 & $\begin{array}{l}\text { Lasioglossum } \\
\text { villosulum }\end{array}$ & Belgium, Brussels, Auderghem & 2015 & leg. A. Pauly & LCO1490/HCO2198 & MK388887 \\
\hline AP239 & $\begin{array}{l}\text { Lasioglossum } \\
\text { villosulum }\end{array}$ & Algeria, Guelma, El Fedjoudj & 2016 & leg. A. Laouar & BarbeeF/MtD9 & MK388888 \\
\hline AP240 & $\begin{array}{l}\text { Lasioglossum } \\
\text { villosulum }\end{array}$ & Algeria, Batna, Lahrayek & 2015 & leg. H. Chichoune & LCO1490/HCO2198 & MK388889 \\
\hline AP241 & $\begin{array}{c}\text { Lasioglossum } \\
\text { medinai } \\
\text { (Vachal, 1895) }\end{array}$ & France, Lot, Le Montat & 2012 & leg. P. Christophe & BarbeeF/MtD9 & MK388890 \\
\hline AP242 & $\begin{array}{l}\text { Lasioglossum } \\
\text { medinai }\end{array}$ & France, Charente Maritime, Saintes & 2012 & leg. N. Sérès & LCO1490/HCO2198 & MK388891 \\
\hline AP243 & $\begin{array}{l}\text { Lasioglossum } \\
\text { medinai }\end{array}$ & $\begin{array}{l}\text { France, Drôme, Saint-Gervais sur } \\
\text { Roubion }\end{array}$ & 2007 & leg. G. de Premorel & BarbeeF/MtD9 & MK388892 \\
\hline AP245 & $\begin{array}{l}\text { Lasioglossum } \\
\text { medinai }\end{array}$ & France, Rhône, Lyon & 2011 & leg. L. Motino & BarbeeF/MtD9 & MK388893 \\
\hline AP247 & $\begin{array}{l}\text { Lasioglossum } \\
\text { medinai }\end{array}$ & France, Aude, Arzens Bellevue & 2014 & leg. D. Genoud & LCO1490/HCO2198 & MK388894 \\
\hline AP249 & $\begin{array}{l}\text { Lasioglossum } \\
\text { medinai }\end{array}$ & Israel, Judean foothills, Mevo Horon & 2011 & leg. Y. Mandelik & LCO1490/HCO2198 & MK388895 \\
\hline AP250 & $\begin{array}{l}\text { Lasioglossum } \\
\text { villosulum }\end{array}$ & Spain, Almeria, Almerimar & 2014 & leg. A. Pauly & BarbeeF/MtD9 & MK388896 \\
\hline AP257 & $\begin{array}{c}\text { Lasioglossum } \\
\text { berberum } \\
\text { (Benoist, 1941) }\end{array}$ & Algeria, Biskra, Dar Arous & 2009 & Leg. H. Djouama & LCO1490/HCO2198 & MK388901 \\
\hline AP391 & $\begin{array}{l}\text { Lasioglossum } \\
\text { medinai }\end{array}$ & $\begin{array}{l}\text { France, Saint-Marcel-sur-Aude, Le Four } \\
\text { à Cahux }\end{array}$ & 2014 & leg. D. Genoud & BarbeeF/MtD9 & MK388897 \\
\hline AP392 & $\begin{array}{l}\text { Lasioglossum } \\
\text { medinai }\end{array}$ & Spain, Segovia, Rio Milanillos & 2012 & leg. Ortiz-Sanchez & BarbeeF/MtD9 & MK388898 \\
\hline AP393 & $\begin{array}{l}\text { Lasioglossum } \\
\quad \text { medinai }\end{array}$ & France, Cléré-sur-layon, La Paguerie & 2013 & leg. O. Durand & BarbeeF/MtD9 & MK388899 \\
\hline AP394 & $\begin{array}{l}\text { Lasioglossum } \\
\quad \text { medinai }\end{array}$ & France, Vaucluse, Cucuron & 2005 & leg. G. Carré & BarbeeF/MtD9 & MK388900 \\
\hline
\end{tabular}




\section{DNA amplification}

Two pairs of primers were used to amplify the 5' end of the cytochrome $c$ oxidase subunit I (COI) mitochondrial gene (the standard DNA barcode region for animals). Primers LCO1490 and HCO2198 (Folmer et al. 1994) were used first on all specimens and, when amplification failed or the sequence was not valid (contamination or multiple peaks), a second primer pair, BarBeeF (Françoso \& Arias 2013) and MtD9 (Simon et al. 1994) was used (Table 1). Each reaction of $25 \mu$ l contained $2 \mu 1$ of DNA template, $0.03 \mathrm{U} / \mu 1$ of Platinum ${ }^{\circledR}$ Taq DNA Polymerase (Life Technologies, USA), 1X PCR buffer, $0.2 \mathrm{mM}$ dNTPs, $0.4 \mu \mathrm{M}$ of each primer and $1.5 \mathrm{mM} \mathrm{MgCl}_{2}$ as used in Pauly et al. (2015). PCR profile for the first set of primers began with $3 \mathrm{~min}$ at $94^{\circ} \mathrm{C}$, then 40 cycles of $30 \mathrm{~s}$ at $94^{\circ} \mathrm{C}, 30 \mathrm{~s}$ at $48^{\circ} \mathrm{C}$ and 45 s at $72^{\circ} \mathrm{C}$ and finished with $7 \mathrm{~min}$ at $72^{\circ} \mathrm{C}$. For the second set of primers, the PCR profile was: $3 \mathrm{~min}$ at $94^{\circ} \mathrm{C}, 5$ cycles of $30 \mathrm{~s}$ at $94^{\circ} \mathrm{C}, 30 \mathrm{~s}$ at $45^{\circ} \mathrm{C}$ and $45 \mathrm{~s}$ at $72^{\circ} \mathrm{C}$ and then 35 cycles of $30 \mathrm{~s}$ at $94^{\circ} \mathrm{C}, 30 \mathrm{~s}$ at $48^{\circ} \mathrm{C}$ and $45 \mathrm{~s}$ at $72^{\circ} \mathrm{C}$. This profile finished with $7 \mathrm{~min}$ at $72^{\circ} \mathrm{C}$.

\section{DNA sequencing}

PCR products were sequenced in both directions with an ABI 3130xl sequencer using BigDye ${ }^{\circledR}$ Terminator ver. 3.1 Cycle Sequencing Kit (Life Technologies, USA). The contigs obtained from both primers were assembled, checked, edited and trimmed in CodonCode Aligner $\bigcirc$ ver. 5.0.1 (CodonCode Corp., Centerville, Massachusetts). Consensus sequences were produced for all bees sampled and they ranged between $412 \mathrm{bp}$ and $676 \mathrm{bp}$. A BLAST search was performed for all of them in order to detect and exclude obvious contaminations.

\section{Molecular and phylogenetic analysis}

All 22 sequences obtained here (with accession numbers from MK388879 to MK388901) were merged with all 80 additional unique barcode sequences retrieved from GenBank and BOLD (using keywords "Lasioglossum villosulum COI" and "Lasioglossum villosulum", respectively, on 23 January 2018) and with barcode data provided by Professor Laurence Packer from BOLD on November 2018 (Table 2). One barcode of Lasioglossum bluethgeni, a halictid belonging to the subgenus Evylaeus Robertson, 1902 (AP222; Table 1), was added as outgroup to root phylogenetic trees. All COI sequences were aligned using ClustalW (Larkin et al. 2007) with the default parameters implemented and pairwise deletion for gaps treatment in MEGA ver. 7.0.21 (Kumar et al. 2016). After quality control of all barcodes, the obtained alignment included at most 658 nucleotide characters. For a first distance-based analysis, pairwise p-distances (i.e., proportion of variable sites) were computed and a Neighbour-Joining (NJ) tree was reconstructed with MEGA ver. 7.0.21 with bootstrap pseudo-replicates $(n=1000)$.

For phylogenetic analysis, we extracted the unique haplotypes from the DNA sequence dataset obtained above using the ape (Paradis \& Schliep 2018) and pegas (Paradis 2010) packages in RStudio ver. 3.5.1 (2018). Label details of each haplotype are given in Table 3. Maximum likelihood (ML) and Bayesian inference (BI) methods were conducted using GARLI ver. 2.1 (Zwickl 2006) and Mr Bayes ver. 3.2.6 (Ronquist et al. 2012), respectively. The best substitution model for each codon position $\left(1^{\text {st }}, 2^{\text {nd }}\right.$ and $3^{\text {nd }}$ codon position) was searched using PartitionFinder2 ver. 2.1.1 (Lanfear et al. 2017), with linked branch lengths parameter, the AICc model selection metrics and the greedy search algorithm (Lanfear et al. 2012). The chosen models for partitioned codon position of COI were: $\operatorname{TIM}+\mathrm{G}\left(1^{\mathrm{st}}\right), \operatorname{TrN}+\mathrm{I}\left(2^{\text {nd }}\right)$ and $\mathrm{F} 81+\mathrm{I}\left(3^{\text {rd }}\right)$. For ML analysis, we configured a group of independent runs: 10 runs for conducting bootstrapping (ntotal $=1000 ; \mathrm{n} / \mathrm{run}=100$ ) and another run for searching the best ML tree. A random unconstrained starting tree was used for each run and automated stopping criterion was applied: when ln score remained constant for 10000 consecutive generations for bootstrap calculation and 100000 consecutive generations for the best ML tree with a required score improvement for topology of minimum 0.01 and 0.00001, respectively. The set of ML trees generated in GARLI (best ML tree +10 ML trees resulting from the ten bootstrapping runs treesmethod in Newick format) were summarized 
Table 2. Barcodes sequences of Lasioglossum villosulum (Kirby, 1802) retrieved from GenBank and BOLD with their accession number or BOLD process ID, collection country and reference.

\begin{tabular}{|c|c|c|c|c|c|}
\hline GenBank/BOLD & Country & Reference & GenBank/BOLD & Country & Reference \\
\hline AF104642 & France & Danforth 1999 & BEEEE059-15 & England & Tang et al. 2018 \\
\hline AF435364 & Spain & Danforth 2002 & BEEEE106-15 & England & No reference \\
\hline GU705888 & Germany & Schmidt et al. 2015 & BEEEE326-16 & England & No reference \\
\hline JQ909783 & Ireland & Magnacca \& Brown 2012 & GMGMA1113-14 & Germany & No reference \\
\hline JQ909784 & Ireland & Magnacca \& Brown 2012 & GMGMB1509-14 & Germany & No reference \\
\hline JQ909785 & Ireland & Magnacca \& Brown 2012 & GMGMB660-14 & Germany & No reference \\
\hline JQ909786 & Ireland & Magnacca \& Brown 2012 & GMGMC872-14 & Germany & No reference \\
\hline KJ836810 & Germany & Schmidt et al. 2015 & GMGME202-14 & Germany & No reference \\
\hline KJ836844 & Germany & Schmidt et al. 2015 & GMGMH624-14 & Germany & No reference \\
\hline KJ836857 & Germany & Schmidt et al. 2015 & GMGMI1082-14 & Germany & No reference \\
\hline KJ837085 & Germany & Schmidt et al. 2015 & GMGMI407-14 & Germany & No reference \\
\hline KJ837457 & Germany & Schmidt et al. 2015 & GMGML649-14 & Germany & No reference \\
\hline KJ837665 & Germany & Schmidt et al. 2015 & GMGMN583-14 & Germany & No reference \\
\hline KJ837678 & Germany & Schmidt et al. 2015 & KX824765 & Azores (Spain) & Weissman et al. 2017 \\
\hline KJ837833 & Germany & Schmidt et al. 2015 & KX824766 & Azores (Spain) & Weissman et al. 2017 \\
\hline KJ838208 & Germany & Schmidt et al. 2015 & KX824767 & Azores (Spain) & Weissman et al. 2017 \\
\hline KJ838409 & Turkey & Schmidt et al. 2015 & KX824768 & Azores (Spain) & Weissman et al. 2017 \\
\hline KJ838863 & Germany & Schmidt et al. 2015 & KX824769 & Azores (Spain) & Weissman et al. 2017 \\
\hline KJ839019 & France & Schmidt et al. 2015 & KX824770 & Azores (Spain) & Weissman et al. 2017 \\
\hline KJ839155 & Germany & Schmidt et al. 2015 & JF903563 & France & Gibbs et al. 2012 \\
\hline KR931723 & Canada & Hebert et al. 2016 & ACUFI641-13 & Finland & No reference \\
\hline ВСНYМ2460-14 & Germany & No reference & DLII1641-09 & France & No reference \\
\hline ВСНYМ2461-14 & Germany & No reference & GBMIX809-14 & Germany & No reference \\
\hline ВСНYM3040-14 & Germany & No reference & GBMIX810-14 & Germany & No reference \\
\hline ВСНYM4651-14 & Germany & No reference & GMBUC405-14 & Bulgaria & No reference \\
\hline BEECA132-06 & Canada & No reference & GMBUE1651-14 & Bulgaria & No reference \\
\hline BEECA133-06 & Canada & No reference & GMBUE693-14 & Bulgaria & No reference \\
\hline BEECB254-07 & Canada & No reference & GMBUF200-14 & Bulgaria & No reference \\
\hline BEECB255-07 & Canada & No reference & GMBUG219-14 & Bulgaria & No reference \\
\hline BEECE374-10 & France & No reference & LASNA081-08 & France & No reference \\
\hline BEECF996-13 & Canada & No reference & LASNA084-08 & France & No reference \\
\hline BOFMD017-10 & Israel & No reference & LASNA089-08 & France & No reference \\
\hline BOWGF1582-10 & USA & No reference & LASNA090-08 & France & No reference \\
\hline BOWGF1584-10 & USA & No reference & LASNA091-08 & France & No reference \\
\hline BOWGF3178-14 & Ukraine & No reference & LASNA092-08 & France & No reference \\
\hline DLII1409-08 & Canada & No reference & LASNA743-08 & Israel & No reference \\
\hline DLII1616-09 & France & No reference & LASNA837-08 & Israel & No reference \\
\hline DLII1622-09 & France & No reference & NOAPI297-14 & Norway & No reference \\
\hline DLII1625-09 & France & No reference & NOAPI298-14 & Norway & No reference \\
\hline DLII1627-09 & France & No reference & NOAPI299-14 & Norway & No reference \\
\hline
\end{tabular}


Table 3 (continued on next two pages). Haplotype details of 103 COI sequences.

\begin{tabular}{|c|c|c|}
\hline Haplotype & Number of sequences & Sequence labels \\
\hline \multirow{4}{*}{$\mathbf{I}$} & \multirow{4}{*}{4} & AF104642.1 Lasioglossum villosulum France \\
\hline & & AP236.2 Lasioglossum villosulum Spain \\
\hline & & AP250.2 Lasioglossum villosulum Spain \\
\hline & & KJ837665.1 Lasioglossum villosulum Germany \\
\hline \multirow{8}{*}{ II } & \multirow{8}{*}{8} & AF435364.1 Lasioglossum villosulum Spain \\
\hline & & AP240.1 Lasioglossum villosulum Algeria \\
\hline & & KX824765.1 Lasioglossum villosulum Spain (Azores) \\
\hline & & KX824767.1 Lasioglossum villosulum Spain (Azores) \\
\hline & & KX824768.1 Lasioglossum villosulum Spain (Azores) \\
\hline & & KX824769.1 Lasioglossum villosulum Spain (Azores) \\
\hline & & KX824770.1 Lasioglossum villosulum Spain (Azores) \\
\hline & & JF903563.1 Lasioglossum villosulum France \\
\hline III & 1 & AP222.2 Lasioglossum bluethgeni Greece \\
\hline \multirow{24}{*}{ IV } & \multirow{24}{*}{24} & AP231.1 Lasioglossum villosulum France \\
\hline & & AP232.1 Lasioglossum villosulum France \\
\hline & & KJ837085.1 Lasioglossum villosulum Germany \\
\hline & & KJ838208.1 Lasioglossum villosulum Germany \\
\hline & & KJ839019.1 Lasioglossum villosulum France \\
\hline & & GMGMA111314 Lasioglossum villosulum Germany \\
\hline & & GMGMB150914 Lasioglossum villosulum Germany \\
\hline & & GMGMB66014 Lasioglossum villosulum Germany \\
\hline & & GMGMC87214 Lasioglossum villosulum Germany \\
\hline & & GMGME20214 Lasioglossum villosulum Germany \\
\hline & & GMGMH62414 Lasioglossum villosulum Germany \\
\hline & & GMGMI108214 Lasioglossum villosulum Germany \\
\hline & & GMGMI40714 Lasioglossum villosulum Germany \\
\hline & & GMGML64914 Lasioglossum villosulum Germany \\
\hline & & GMGMN58314 Lasioglossum villosulum Germany \\
\hline & & BCHYM3040-14 Hymenoptera Germany \\
\hline & & DLII1616-09 Hymenoptera France \\
\hline & & DLII1622-09 Lasioglossum villosulum France \\
\hline & & DLII1627-09 Hymenoptera France \\
\hline & & GMBUC405-14 Hymenoptera Bulgaria \\
\hline & & GMBUE1651-14 Hymenoptera Bulgaria \\
\hline & & GMBUG219-14 Hymenoptera Bulgaria \\
\hline & & LASNA089-08 Lasioglossum villosulum France \\
\hline & & LASNA090-08 Lasioglossum villosulum France \\
\hline \multirow{2}{*}{$\mathbf{V}$} & \multirow{2}{*}{2} & AP233.1 Lasioglossum villosulum France \\
\hline & & AP237.1 Lasioglossum villosulum Belgium \\
\hline
\end{tabular}


Table 3 (continued). Haplotype details of 103 COI sequences.

\begin{tabular}{|c|c|c|}
\hline Haplotype & Number of sequences & Sequence labels \\
\hline \multirow{20}{*}{ VI } & \multirow{20}{*}{20} & AP234.1 Lasioglossum villosulum France \\
\hline & & AP238.1 Lasioglossum villosulum Belgium \\
\hline & & GU705888.1 Lasioglossum villosulum Germany \\
\hline & & KJ836810.1 Lasioglossum villosulum Germany \\
\hline & & KJ836844.1 Lasioglossum villosulum Germany \\
\hline & & KJ836857.1 Lasioglossum villosulum Germany \\
\hline & & KJ837457.1 Lasioglossum villosulum Germany \\
\hline & & KJ838863.1 Lasioglossum villosulum Germany \\
\hline & & BEEEE05915 Lasioglossum villosulum England \\
\hline & & BEEEE10615 Lasioglossum villosulum England \\
\hline & & BEEEE32616 Lasioglossum villosulum England \\
\hline & & BCHYM2460-14 Hymenoptera Germany \\
\hline & & BCHYM2461-14 Hymenoptera Germany \\
\hline & & BCHYM4651-14 Hymenoptera Germany \\
\hline & & BOWGF1584-10 Hymenoptera United States \\
\hline & & GBMIX809-14 Hymenoptera Germany \\
\hline & & GBMIX810-14 Hymenoptera Germany \\
\hline & & GMBUF200-14 Hymenoptera Bulgaria \\
\hline & & NOAPI298-14 Hymenoptera Norway \\
\hline & & NOAPI299-14 Hymenoptera Norway \\
\hline \multirow{2}{*}{ VII } & \multirow{2}{*}{2} & AP235.1 Lasioglossum villosulum France \\
\hline & & KJ837833.1 Lasioglossum villosulum Germany \\
\hline VIII & 1 & AP239.2 Lasioglossum villosulum Algeria \\
\hline \multirow{10}{*}{ IX } & \multirow{10}{*}{10} & AP241.3 Lasioglossum medinai France \\
\hline & & AP242.1 Lasioglossum medinai France \\
\hline & & AP243.3 Lasioglossum medinai France \\
\hline & & AP247.1 Lasioglossum medinai France \\
\hline & & AP392.3 Lasioglossum medinai Spain \\
\hline & & AP394.3 Lasioglossum medinai France \\
\hline & & DLII1625-09 Hymenoptera France \\
\hline & & LASNA081-08 Lasioglossum n sp. cpq France \\
\hline & & LASNA091-08 Lasioglossum n sp. cpq France \\
\hline & & LASNA092-08 Lasioglossum n sp. cpq France \\
\hline \multirow{2}{*}{$\mathbf{X}$} & \multirow{2}{*}{2} & AP245.3 Lasioglossum medinai France \\
\hline & & AP393.3 Lasioglossum medinai France \\
\hline \multirow{2}{*}{ XI } & \multirow{2}{*}{2} & AP249.1 Lasioglossum medinai Israel \\
\hline & & BOFMD017-10 Hymenoptera Israel \\
\hline
\end{tabular}


Table 3 (continued). Haplotype details of 103 COI sequences.

\begin{tabular}{|c|c|c|}
\hline Haplotype & Number of sequences & Sequence labels \\
\hline XII & 1 & AP391.3 Lasioglossum medinai France \\
\hline \multirow{3}{*}{ XIII } & \multirow{3}{*}{3} & JQ909783.1 Lasioglossum villosulum Ireland \\
\hline & & JQ909784.1 Lasioglossum villosulum Ireland \\
\hline & & JQ909785.1 Lasioglossum villosulum Ireland \\
\hline XIV & 1 & JQ909786.1 Lasioglossum villosulum Ireland \\
\hline $\mathbf{X V}$ & 1 & KJ837678.1 Lasioglossum villosulum Germany \\
\hline XVI & 1 & KJ838409.1 Lasioglossum villosulum Turkey \\
\hline XVII & 1 & KJ839155.1 Lasioglossum villosulum Germany \\
\hline \multirow{6}{*}{ XVIII } & \multirow{6}{*}{6} & KR931723.1 Lasioglossum villosulum Canada \\
\hline & & BEECA132-06 Lasioglossum nr villosulum Canada \\
\hline & & BEECA133-06 Lasioglossum nr villosulum Canada \\
\hline & & BEECF996-13 Hymenoptera Canada \\
\hline & & BOWGF1582-10 Hymenoptera United States \\
\hline & & NOAPI297-14 Hymenoptera Norway \\
\hline XIX & 1 & KX824766.1 Spain(Azores) \\
\hline $\mathbf{X X}$ & 1 & AP257 Lasioglossum berberum Algeria \\
\hline XXI & 1 & ACUFI641-13 Hymenoptera Finland \\
\hline \multirow{2}{*}{ XXII } & \multirow{2}{*}{2} & BEECB254-07 Lasioglossum nr villosulum Canada \\
\hline & & BEECB255-07 Lasioglossum nr villosulum Canada \\
\hline XXIII & 1 & BEECE374-10 Hymenoptera France \\
\hline \multirow{2}{*}{ XXIV } & \multirow{2}{*}{2} & BOWGF3178-14 Hymenoptera Ukraine \\
\hline & & LASNA743-08 Hymenoptera Israel \\
\hline XXV & 1 & DLII1409-08 Lasioglossum $\mathrm{nr}$ villosulum Canada \\
\hline XXVI & 1 & DLII1641-09 Hymenoptera France \\
\hline XXVII & 1 & GMBUE693-14 Hymenoptera Bulgaria \\
\hline XXVIII & 1 & LASNA084-08 Lasioglossum villosulum France \\
\hline XXIX & 1 & LASNA837-08 Lasioglossum sp. aff. villosulum Israel \\
\hline
\end{tabular}

in one majority-rule consensus tree (see Fig. 3) with the support values mapped from non-parametric bootstrap calculation using SumTrees ver. 4.3 (Sukumaran \& Holder 2017) in DendroPy (Sukumaran \& Holder 2010). Bootstrap values $\geq 70 \%$ were considered as the threshold for good confidence to tree topologies (Hillis \& Bull 1993).

For BI analyses, the TIM and TrN substitution models are not implemented in MrBayes and were replaced by their closest relative model (Huelsenbeck \& Rannala 2004), the GTR model. Two parallel runs with four chains of Markov Chain Monte Carlo (MCMC) each were run for five million generations and every $1000^{\text {th }}$ generation was sampled. The BI analysis was stopped after checking convergence between both runs using the average standard deviation of split frequencies and the first $25 \%$ of the trees were discarded ('burn-in'). Posterior probabilities were then estimated and a majority-rule consensus tree was constructed (see Fig. 4). Posterior probabilities $\geq 0.95$ were considered as the threshold for good confidence to tree topologies (Wilcox et al. 2002). All phylogenetic trees (ML and BI) were drawn using FigTree ver. 1.4.3 (Rambaut 2017) and the document (.svg) was modified with Inkscape ver. 0.92.2. 


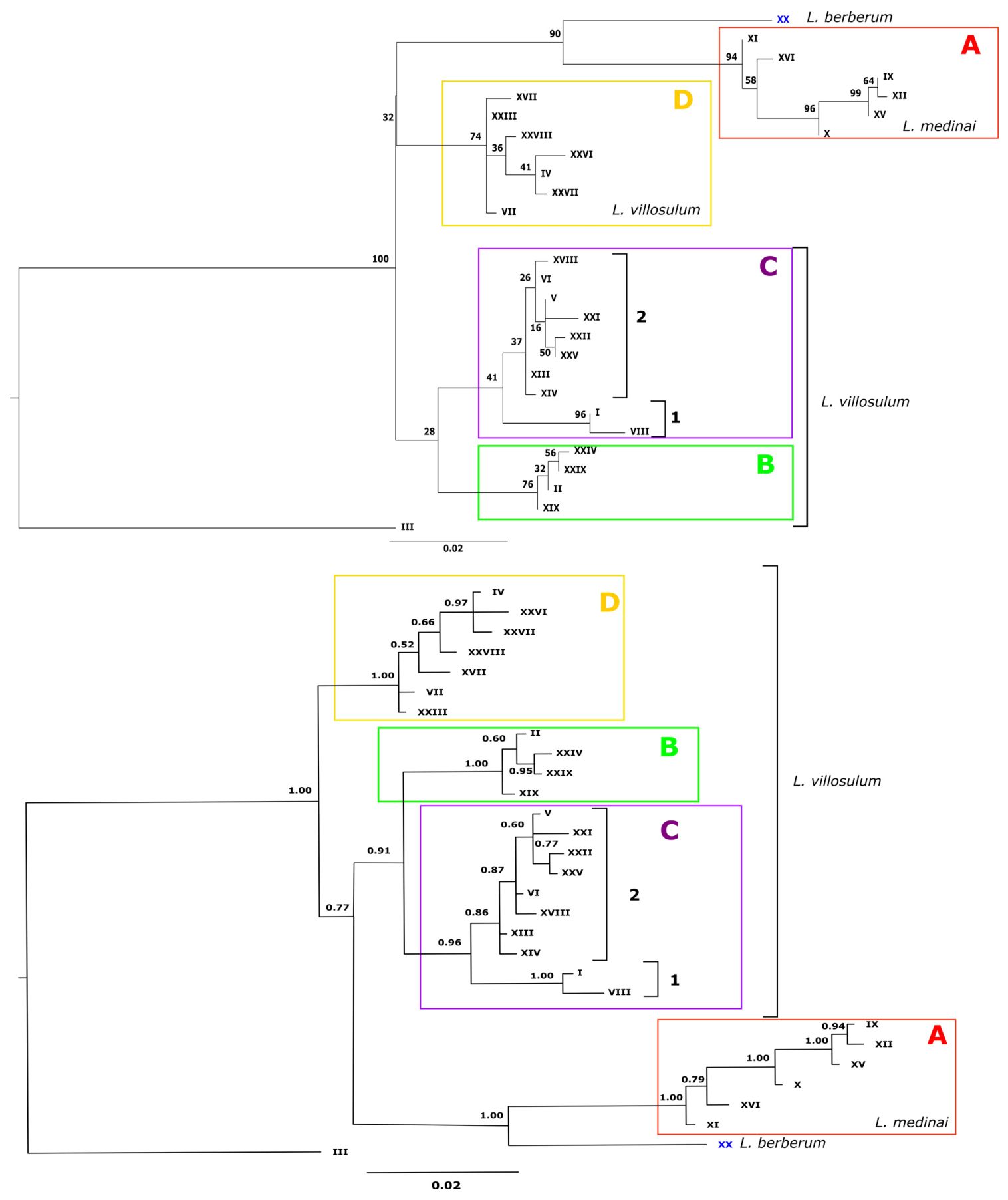

Fig. 3. Trees constructed using maximum likelihood (above) and Bayesian inference (below) and based on 29 haplotype sequences (658bp) of the cytochrome oxidase $c$ subunit I gene of specimens currently identified as Lasioglossum villosulum (Kirby, 1802), Lasioglossum medinai (Vachal, 1895) and one as Lasioglossum berberum (Benoist, 1941). Each label corresponds to one roman letter which encompasses all sequences from a haplotype (for more details see Table 3). A, Lasioglossum medinai; B-D: Lasioglossum villosulum. Label highlighted in blue corresponds to L. berberum. This phylogenetic tree is rooted using Lasioglossum bluethgeni Ebmer, 1971 as outgroup (label III, voucher AP222). Bootstrap support (\%) and posterior probabilities are given at nodes. 


\section{Species delineation analyses}

For species delineation analysis, we generated an ultrametric tree using the BEAST2 ver. 2.5.2 environment (Bouckaert et al. 2014). Following Michonneau (2016), coalescent model with constant population size combined with constant clock was used as prior for expressing the expected topology of the tree. We followed GTR model as in MrBayes analysis with Gamma Category Count of four to capture most of the rate variation. We set-up MCMC length to five million of generation. For the run, we checked the posterior probabilities as well as the effective sample size $(>200)$ with Tracer ver. 1.7.1 program (Rambaut et al. 2018). Then, we summarized Bayesian information into phylogenetic tree via TreeAnnotator ver. 2.5.2. (included in BEAST environment) program with a burn-in of $10 \%$.

As recommended by Tang et al. (2014), we conducted Generalized Mixed Yule Coalescent (GMYC, Fujisawa \& Barraclough 2013; Pons et al. 2006) and Bayesian Poisson Tree Process (bPTP) analyses (Zhang et al. 2017). The ultrametric tree was used as input for the GMYC analysis, which was performed with single threshold approach (Fujisawa \& Barraclough 2013) on RStudio ver. 3.5.1 (2018) using ape, rncl (Michonneau et al. 2018) and splits (Ezard et al. 2017) packages. The bPTP analysis, was

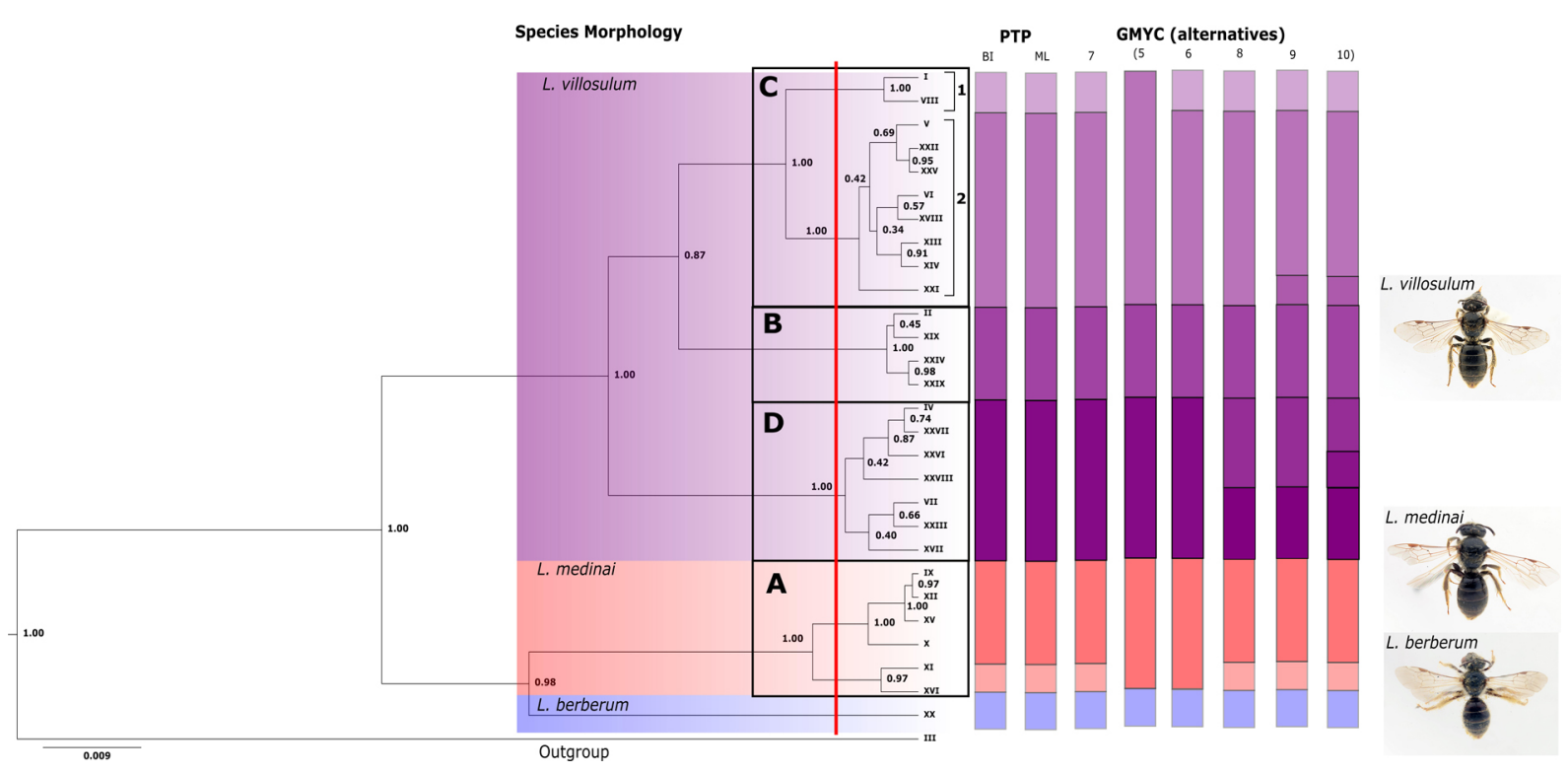

Fig. 4. Ultrametric tree constructed using Bayesian inference and based on 29 haplotype sequences (658bp) of the cytochrome oxidase $c$ subunit I gene of specimens currently identified as Lasioglossum villosulum (Kirby, 1802), Lasioglossum medinai (Vachal, 1895) and one as Lasioglossum berberum (Benoist, 1941). Each label corresponds to one roman letter which encompasses all sequence from a haplotype (for more details see Table 3). A. Lasioglossum medinai; B-D: three supported clusters (a fourth cluster could be defined in C) within Lasioglossum villosulum. This phylogenetic tree is rooted using Lasioglossum bluethgeni Ebmer, 1971 as outgroup (label III, voucher AP222). Posterior probabilities are given at nodes. The three colour gradients on the tree correspond to morphological delineation. Results of the species delimitations analyses are represented on the right side of the figure: the Bayesian Poisson Tree Process (bPTP) analyses based on the trees obtained using Bayesian inference (BI) or maximum likelihood (ML); The Generalized Mixed Yule Coalescent (GMYC) analysis resulting in seven candidate species (using the single threshold represented as a red line on the tree) and five alternative scenarios. Numbers at the top of the columns corresponds to the number of candidate species in the GMYC analysis. 
performed on the Web Server (https://species.h-its.org/ptp/) of The Exelixis Lab with default parameters and using the ultrametric tree as input.

\section{Results}

\section{DNA analyses}

Our COI dataset comprised 29 unique haplotypes: 1 corresponding to the outgroup (Fig. 3; label III or L. bluethgeni), 1 to L. berberum (Fig. 3; label XX), 6 to L. medinai (Fig. 3A) and 21 to L. villosulum (Fig. 3B, C (1-2) and D). All specimens identified as L. medinai and sequenced here cluster together in all phylogenetic analyses, with a bootstrap support of $94 \%$ in the ML analysis, and a posterior probability of one in the Bayesian inferences (ultrametric and non ultrametric trees) (clade A in Fig. 3 and Fig. 4). The haplotype identified as Lasioglossum berberum (haplotype XX highlighted in blue in Fig. 3) appears as a sister-species of L. medinai according to all tree reconstructions. All remaining haplotypes identified as L. villosulum were found on other branches (Fig. 3B-D and Fig. 4). They formed a clade in the ultrametric tree obtained by BI (Fig. 4) but their relationships were not resolved in the other phylogenetic analyses (Fig. 3). They clustered in at least three divergent groups with posterior probabilities of 0.96-1.00 in the BI analysis. Only two of these clusters were supported (with bootstrap values of $74-76 \%$ ) in the ML analysis (Fig. 3).

The GMYC analysis estimated seven candidate species (six clusters of haplotypes and the single haplotype of $L$. berberum (haplotype XX in Fig. 4) with a minimum of five and a maximum of 10 candidates species. The same seven candidate species were suggested using the bPTP approach (Fig. 4). In the species delimitation suggesting the lowest number of species (five candidates species), L. medinai, $L$. berberum and three clades of $L$. villosulum (corresponding to the clades B-D in the phylogenetic trees) were considered as possible distinct species. In the species delimitations proposing more than five species, L. medinai and L. villosulum were further split in two to seven candidate species (Fig. 4). We did not find any diagnostic morphological characters enabling the distinction among these candidate species. They are also not distributed according to geographical patterns.

Intraspecific genetic divergences within and among clusters B, C and D of L. villosulum (ranging from $0 \%$ to $4.8 \%$ ) are comparable to those within the cluster of $L$. medinai (ranging from $0 \%$ to $3.2 \%$ ). In the NJ tree, all specimens identified as $L$. medinai and sequenced here cluster together with maximum bootstrap support (Fig. S1A). In all analyses, the cluster of L. medinai also includes seven sequences from GenBank, two identified as L. villosulum in the study of Schmidt et al. (2015) (accession numbers KJ838409 and KJ837678; highlighted in red colour in Fig. S1, available in Supplementary material) and five records of specimens that were not identified to the species level.

\section{Systematics}

Class Insecta Linnaeus, 1758

Order Hymenoptera Linné, 1758

Family Halictidae Thomson, 1869

Tribe Halictini Thomson, 1869

Genus Lasioglossum Curtis, 1833

Lasioglossum villosulum (Kirby, 1802)

This species was classified in the subgenus Evylaeus Robertson, 1902 by Ebmer (1988) and more recently placed in the subgenus Hemihalictus Cockerell, 1897 by Gibbs et al. (2013). 


\section{Subspecies villosulum}

\section{Synonymy}

Melitta villosula Kirby, 1802: 62. Type: 1 ô, England (NHMUK013380582), male lectotype designated by Ebmer 1988: 649. Examined by DGN (Fig. 6).

Melitta punctulata Kirby, 1802: 66. Type: 1 9, England, [Kent] Barham (NHMUK013380583). Syn. by Dalla Torre 1896: 90. The holotype examined by DGN (Fig. 7), is a typical L. villosulum villosulum, small size, large sparse punctures, etc. It does not agree with the pseudocryptic species.

Halictus hirtellus Schenck, 1869: 311. Type: 1 , Germany, Elberfeld near Letmathe an der Lenne, leg. Cornelius (SMF), lectotype designated by Ebmer 1975: 244; syn. by Blüthgen 1920: 278, 1930: 743. Examined by AP (Fig. 5).

Halictus pauperatulellus Strand, 1909: 44. Holotype: §̂, Algeria, Blidah-Médéah, Jul.-Aug. 1884, leg. Quedenfeldt (MNHUB). Syn. by Blüthgen 1922: 318. Examined by AP (Fig. 8).

Halictus barkensis Blüthgen, 1930: 224. Types: "1 ㅇ, 1 đ’”, Libya, Bengasi, 20 Aug. 1924, coll. Blüthgen (MNHUB), not examined.

Halictus villosulus perlautus Cockerell, 1938a: 82. Holotype: 1 ô, Morocco, Asni, Aug. 1930, leg. Cockerell (NHMUK013380275). Syn. by Warncke 1973: 290. Examined by DGN.

Halictus rufotegularis Cockerell, 1938b: 7. Holotype: 1 \%, Morocco, Ifrane, 27 Aug. 1930, leg. Alice Mackie (AMNH). Syn. by Ebmer 1976: 253 (21 March) and Warncke 1976: 95 (15 October). Examined by AP (Fig. 9).

Halictus villiersi Benoist, 1941: 80. Holotype: + , Morocco, Djebel Tachdirt, 2500 m, 15-31 Aug. (MNHN). Syn. by Warncke 1973: 290. Examined by AP (Fig. 10).

\section{Remarks}

\section{Halictus hirtellus}

The type of Halictus hirtellus Schenck, 1869, was examined by Blüthgen (1920: 278). Blüthgen (1930: 743) also mentions our pseudocryptic species as a form needing more research and he specifies that it is not Halictus hirtellus ("die nicht etwa hirtellus Schck ist"). Ebmer (1975) designated a lectotype from Letmathe an der Lenne ( $\left.51^{\circ} 22^{\prime} \mathrm{N}, 7^{\circ} 36^{\prime} \mathrm{E}\right)$, a locality in Germany, that is out of the distribution of the new sub-Mediterranean pseudocryptic species L. medinai (the specimen from Germany in the cluster of L. medinai comes from a locality further south: Baden-Württemberg, Müllheim, $47^{\circ} 49^{\prime} \mathrm{N}, 7^{\circ} 37^{\prime} \mathrm{E}$ ).

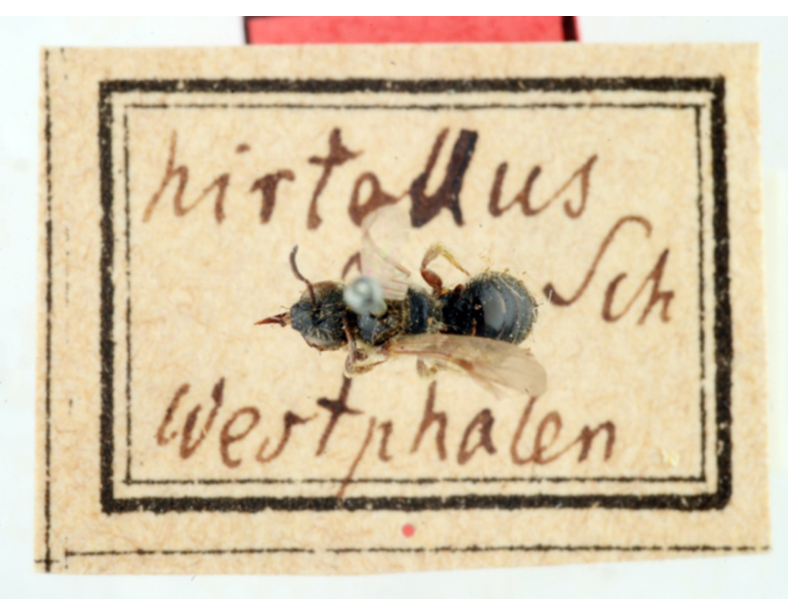

Fig. 5. Halictus hirtellus Schenck, 1896, lectotype, + . 


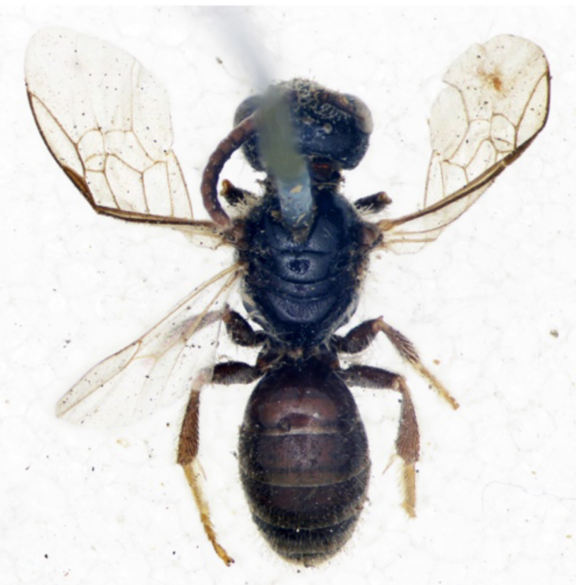

A
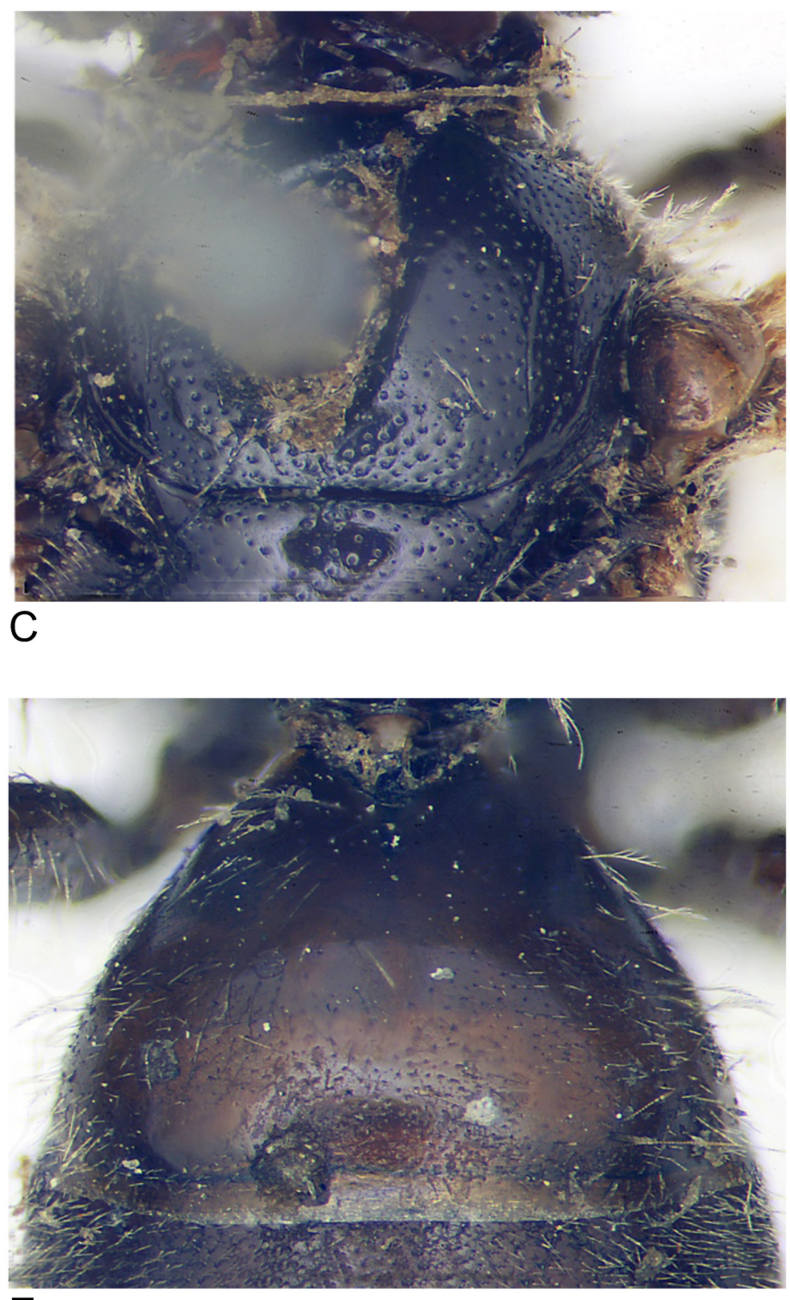

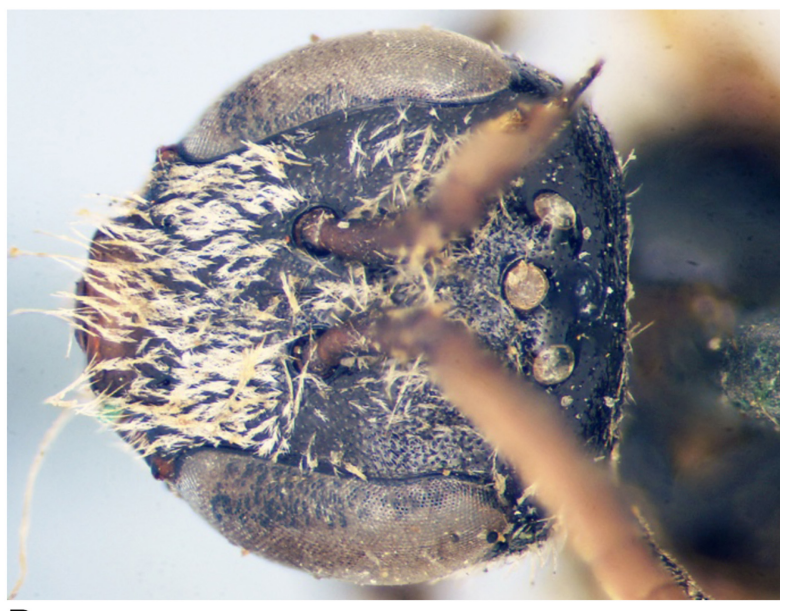

$\mathrm{B}$
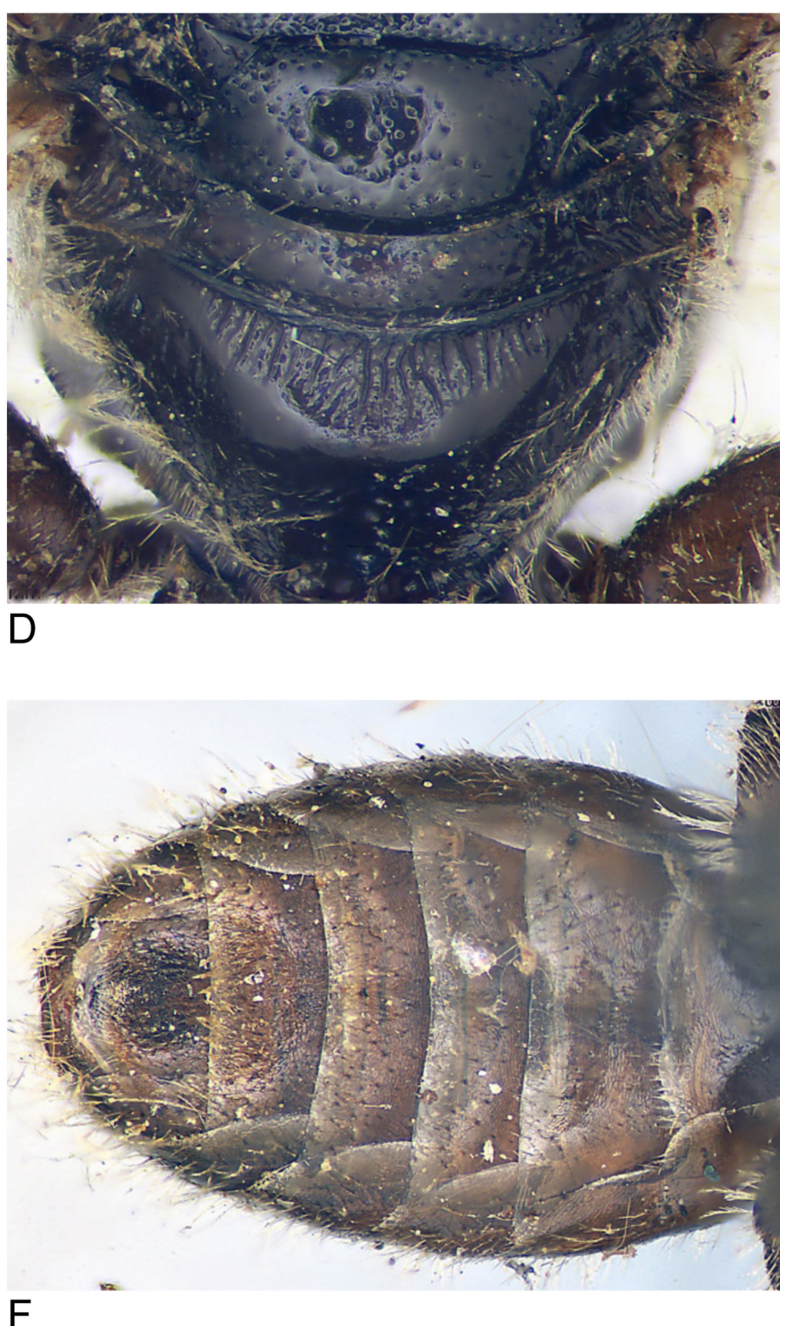

Fig. 6. Melitta villosula Kirby, 1802, lectotype, $\widehat{\jmath}$ (= Lasioglossum villosulum). A. Habitus. B. Head. C. Scutum. D. Propodeum. E. First tergum. F. Sterna. 


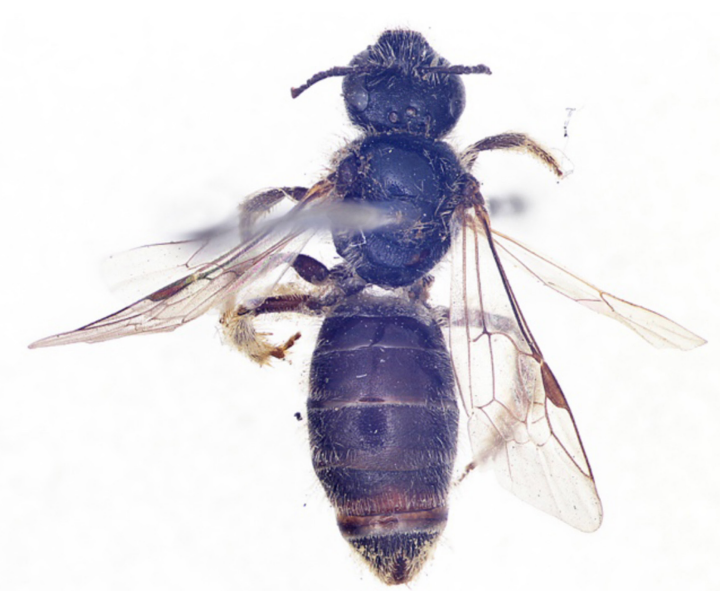

A
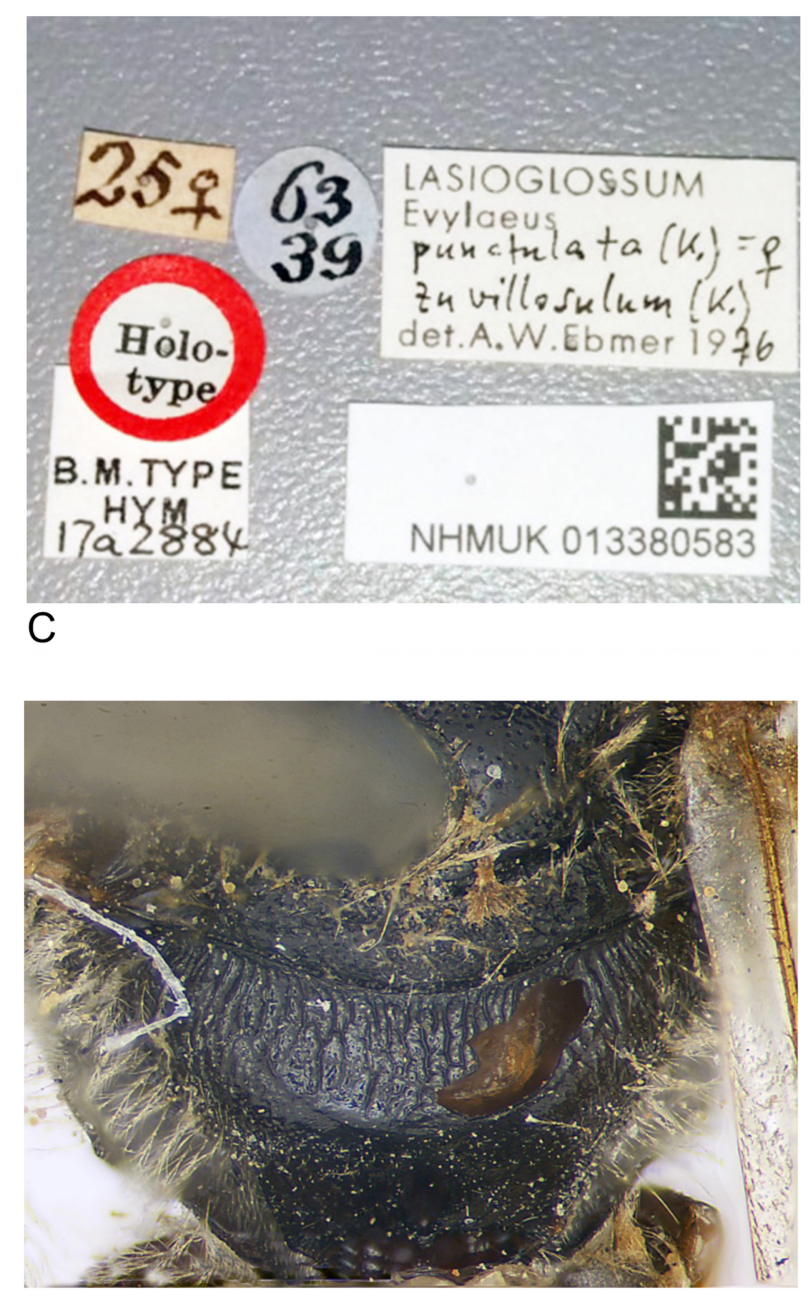

$\mathrm{E}$

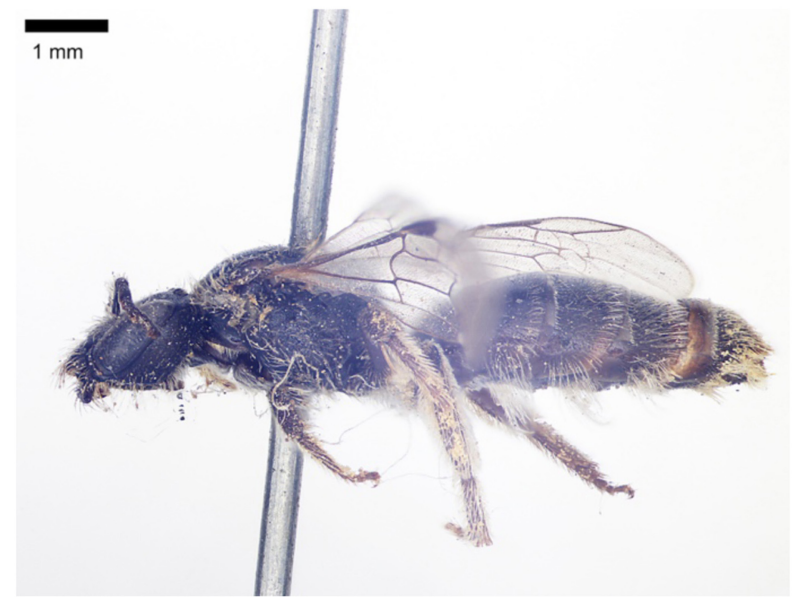

B
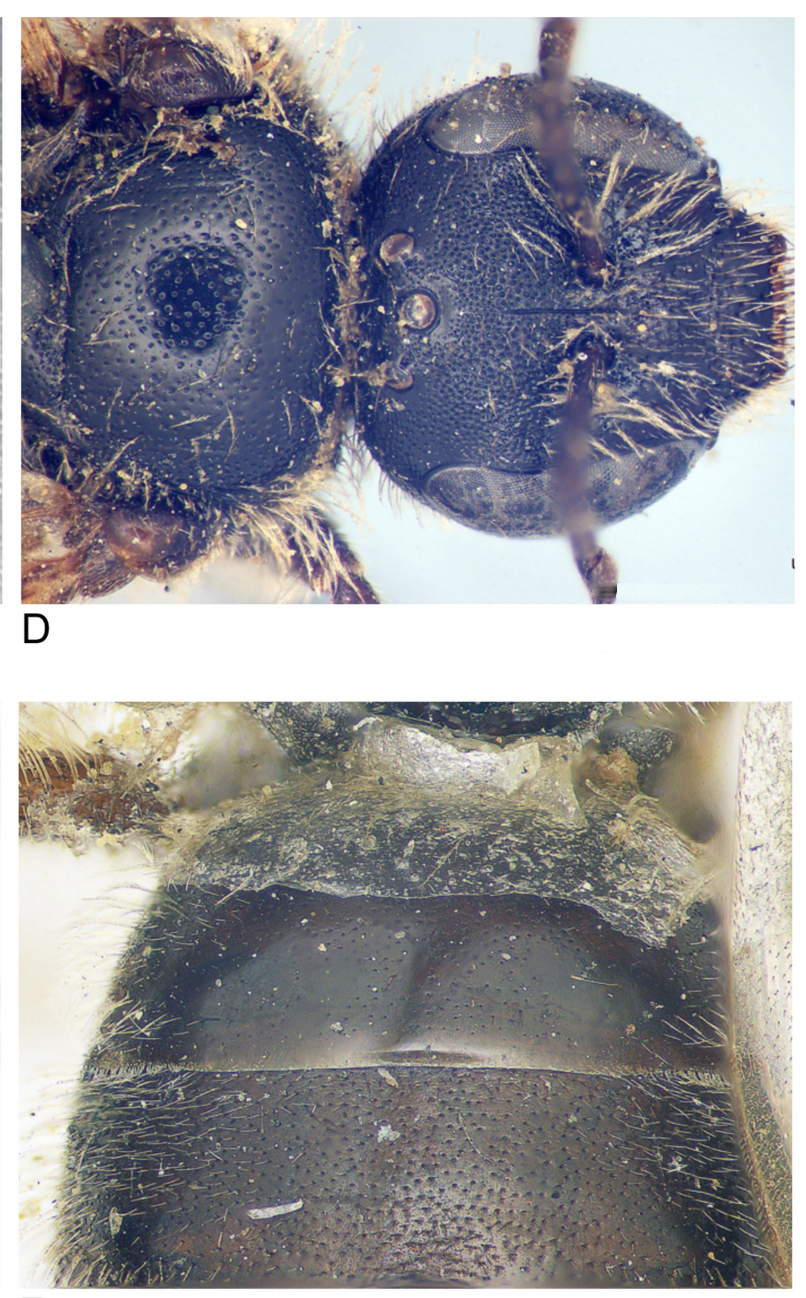

$\mathrm{F}$

Fig. 7. Melitta punctulata Kirby, 1802, holotype, +. A. Habitus, dorsal view. B. Habitus, lateral view. C. Labels. D. Scutum and head. E. Propodeum. F. Tergum 1 and 2 (metasoma glued). 

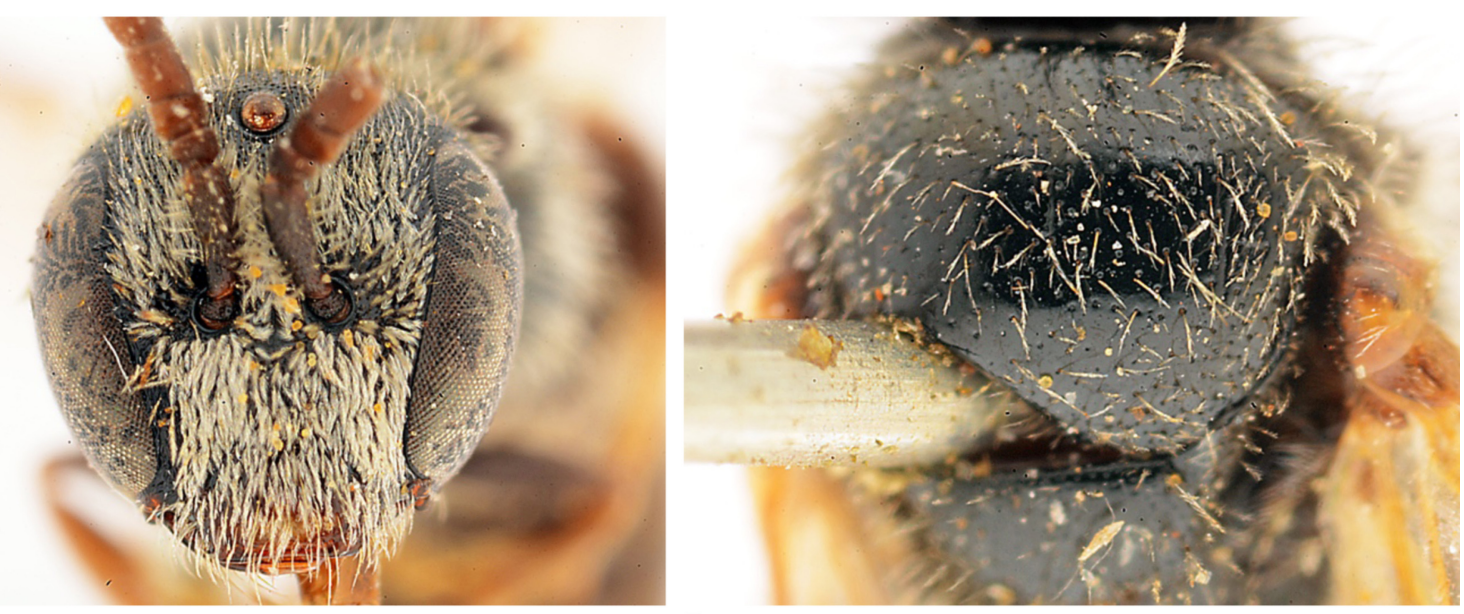

A

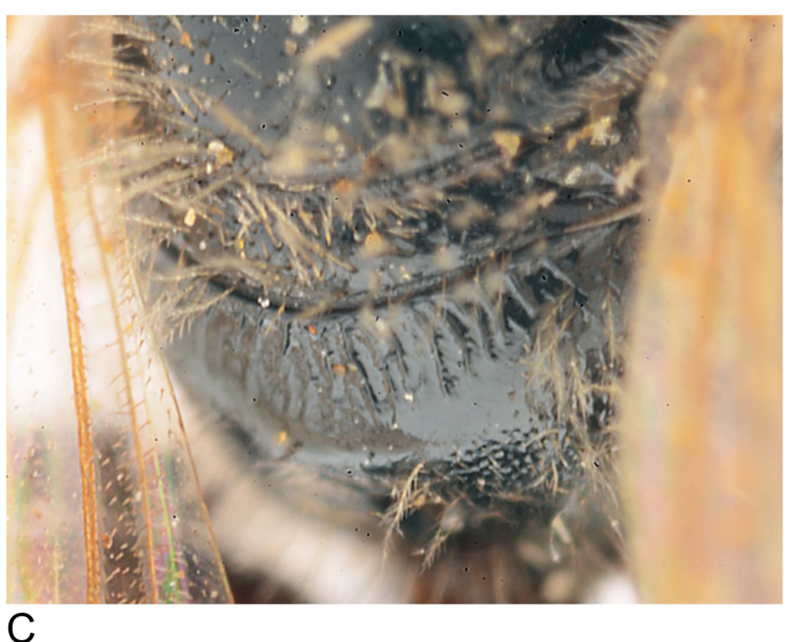

C

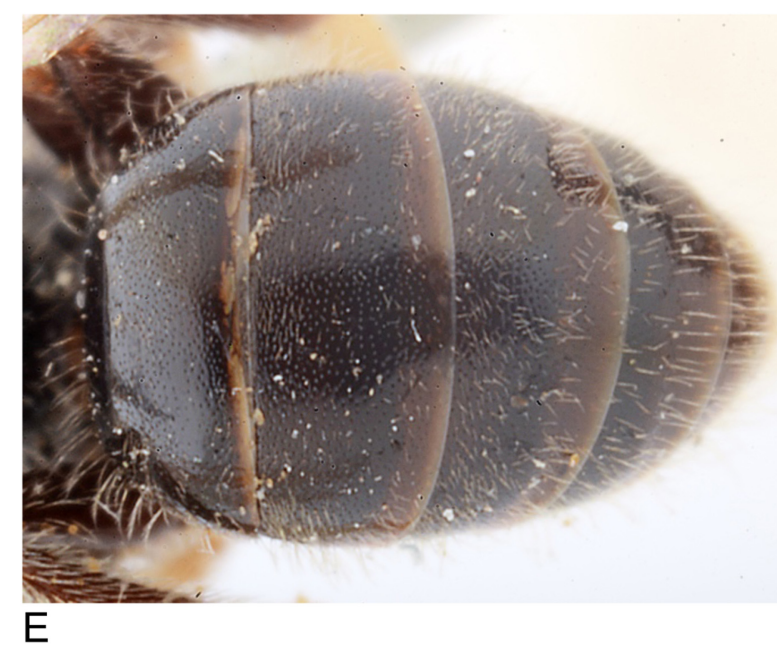

B

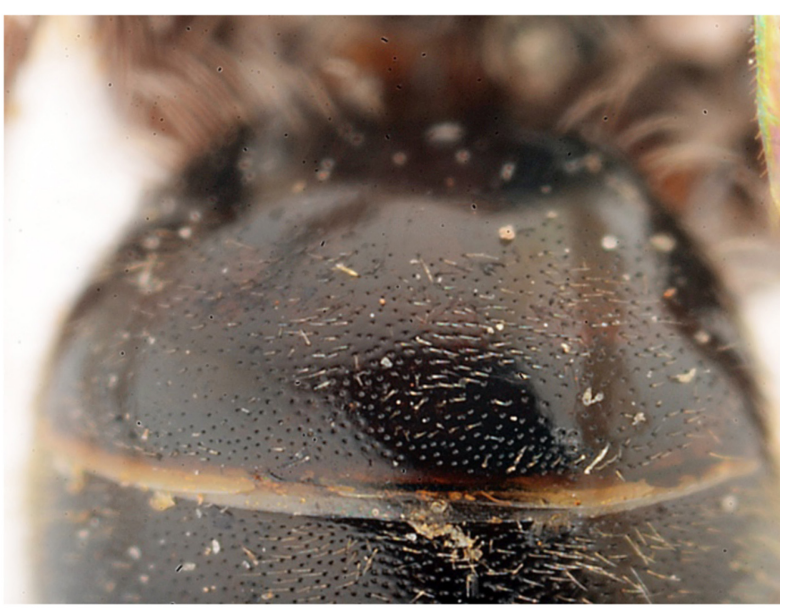

D

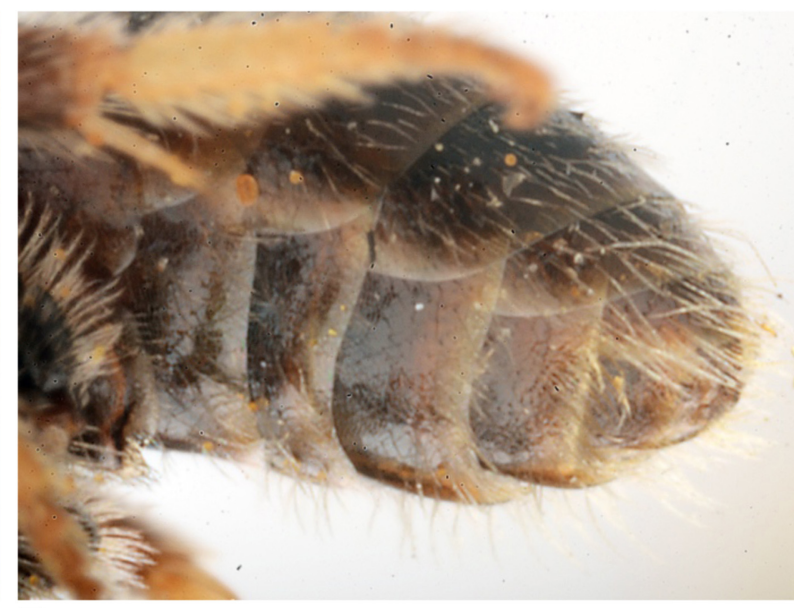

$\mathrm{F}$

Fig. 8. Halictus pauperatulellus Strand, 1909, holotype, ô. A. Head. B. Scutum. C. Propodeum. D. First tergum. E. Metasoma, dorsal view. F Metasoma, ventral view. 


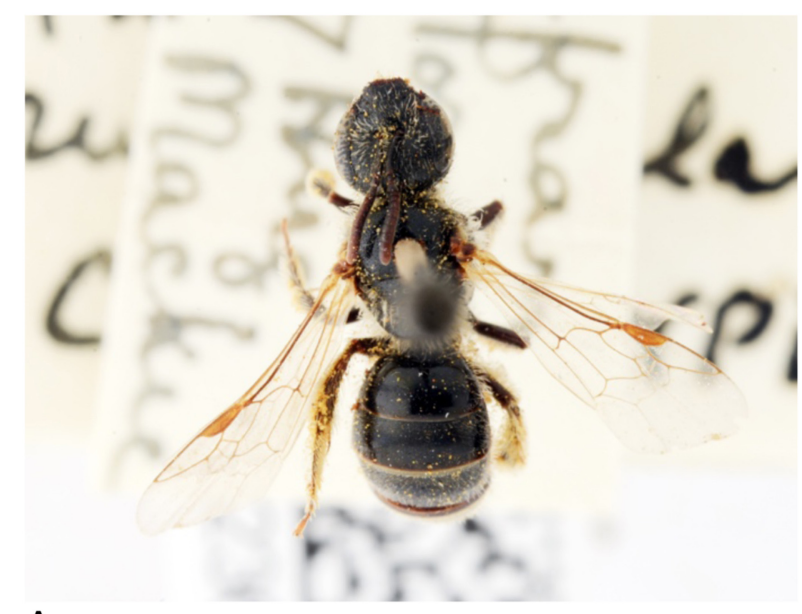

A
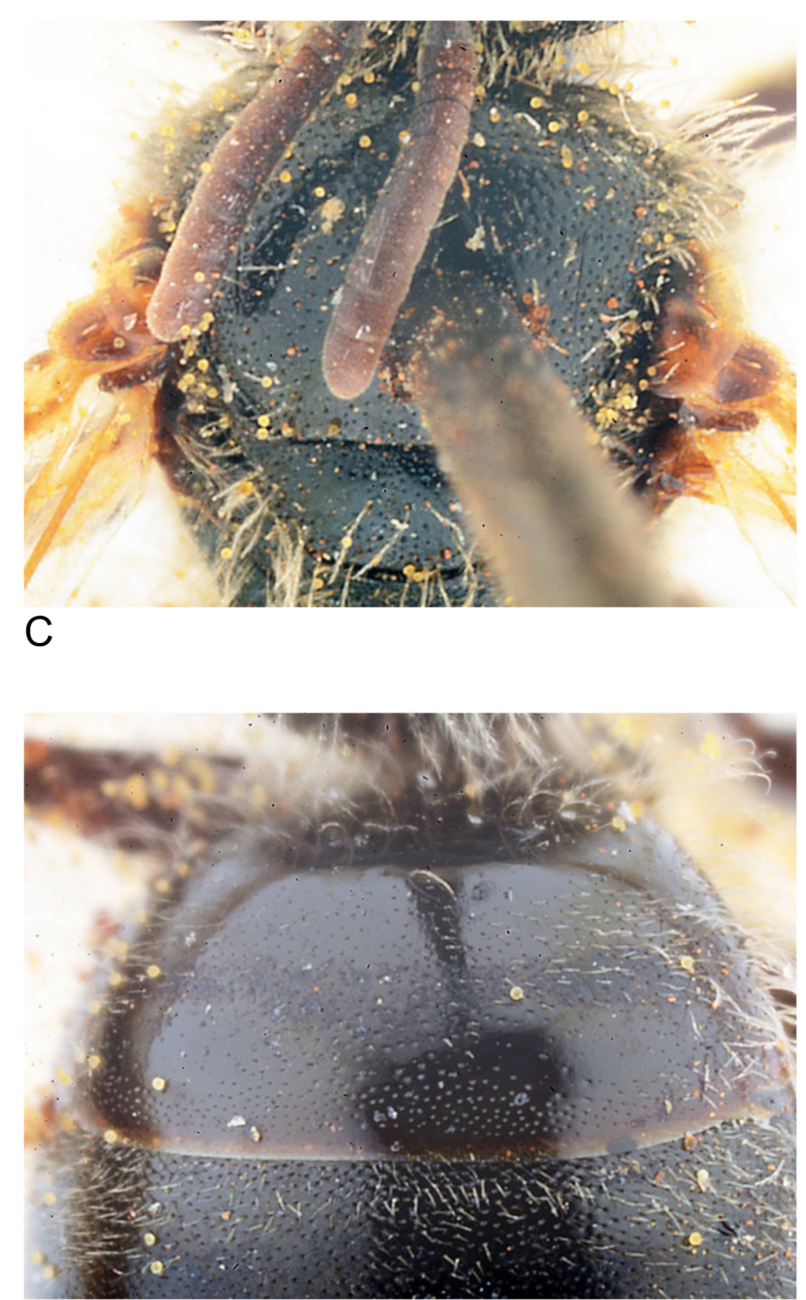

$\mathrm{E}$

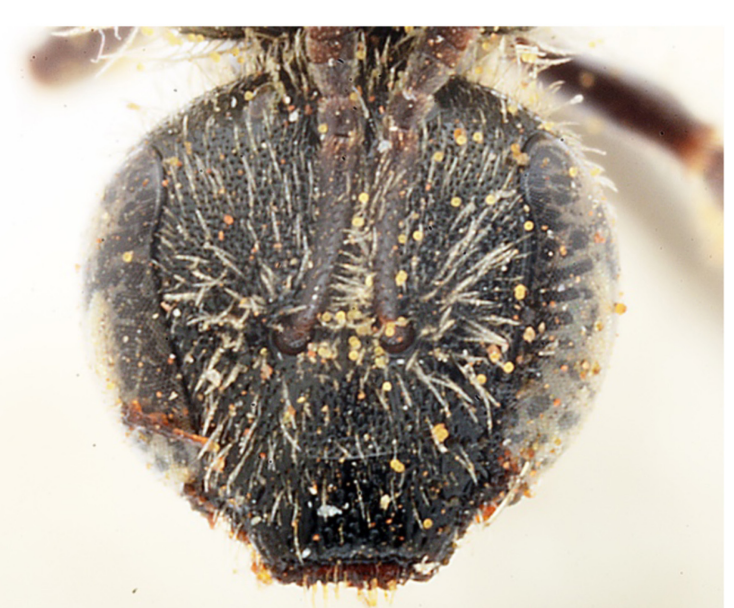

B
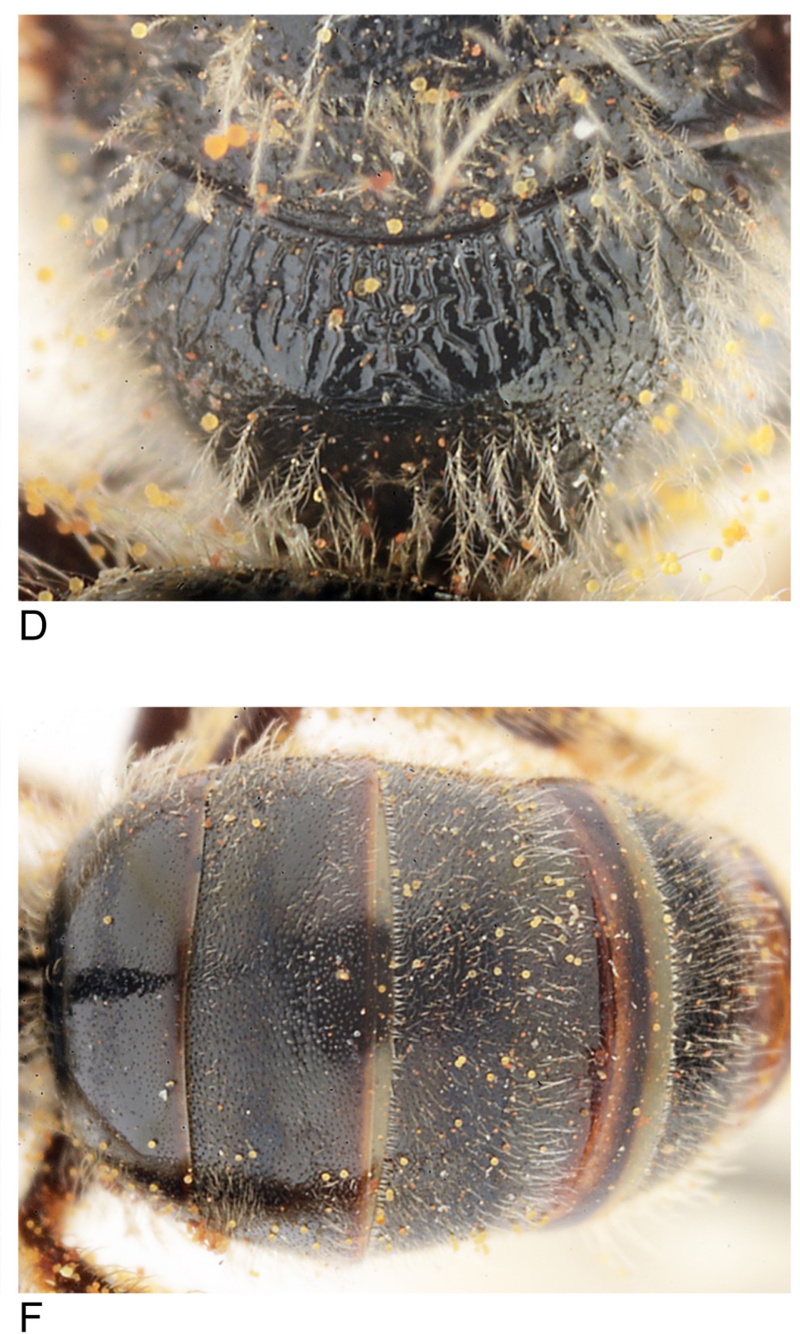

Fig. 9. Halictus rufotegularis Cockerell, 1938, holotype,, . A. Habitus, dorsal view. B. Head. C. Scutum. D. Propodeum. E. First tergum. F. Metasoma. 


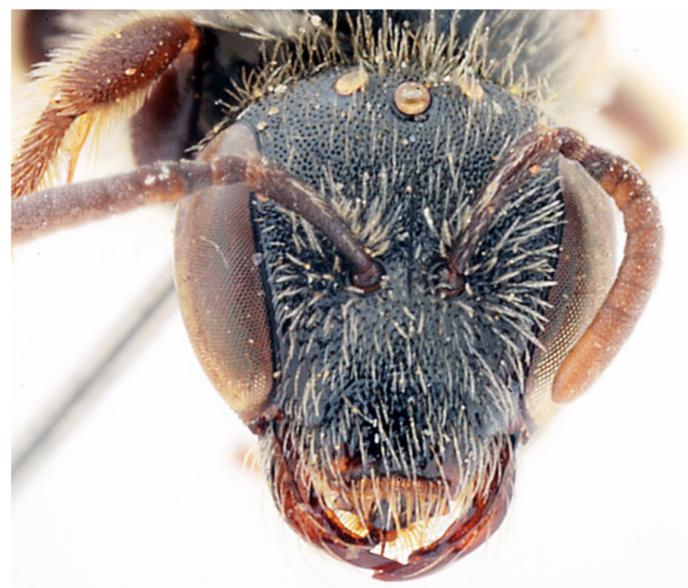

A

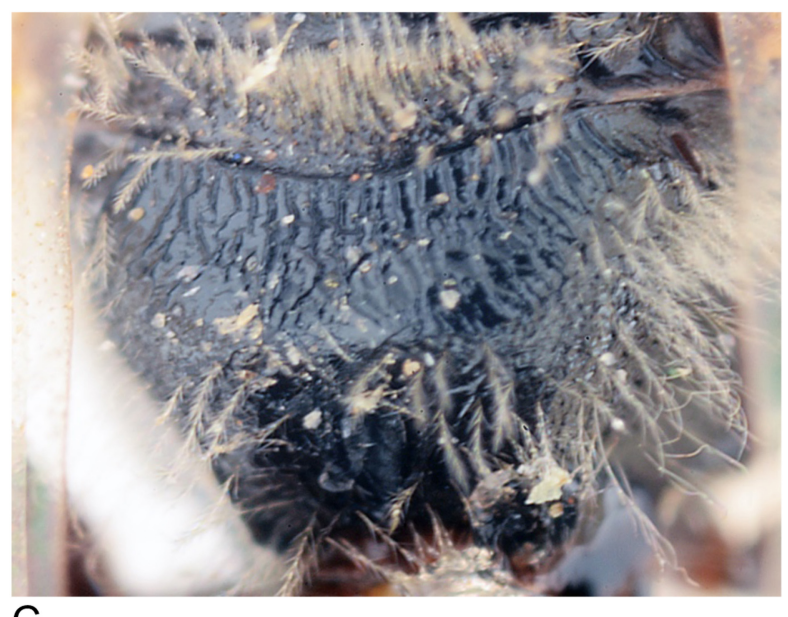

C

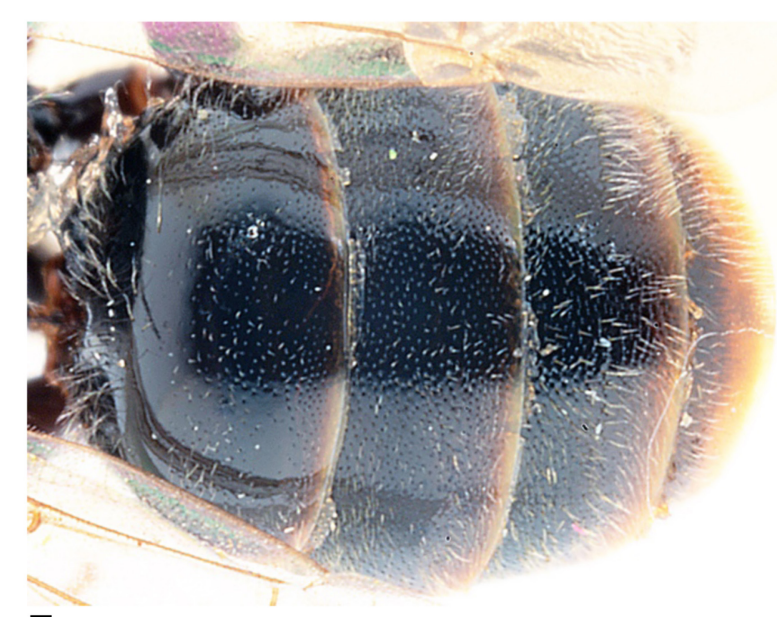

$\mathrm{E}$
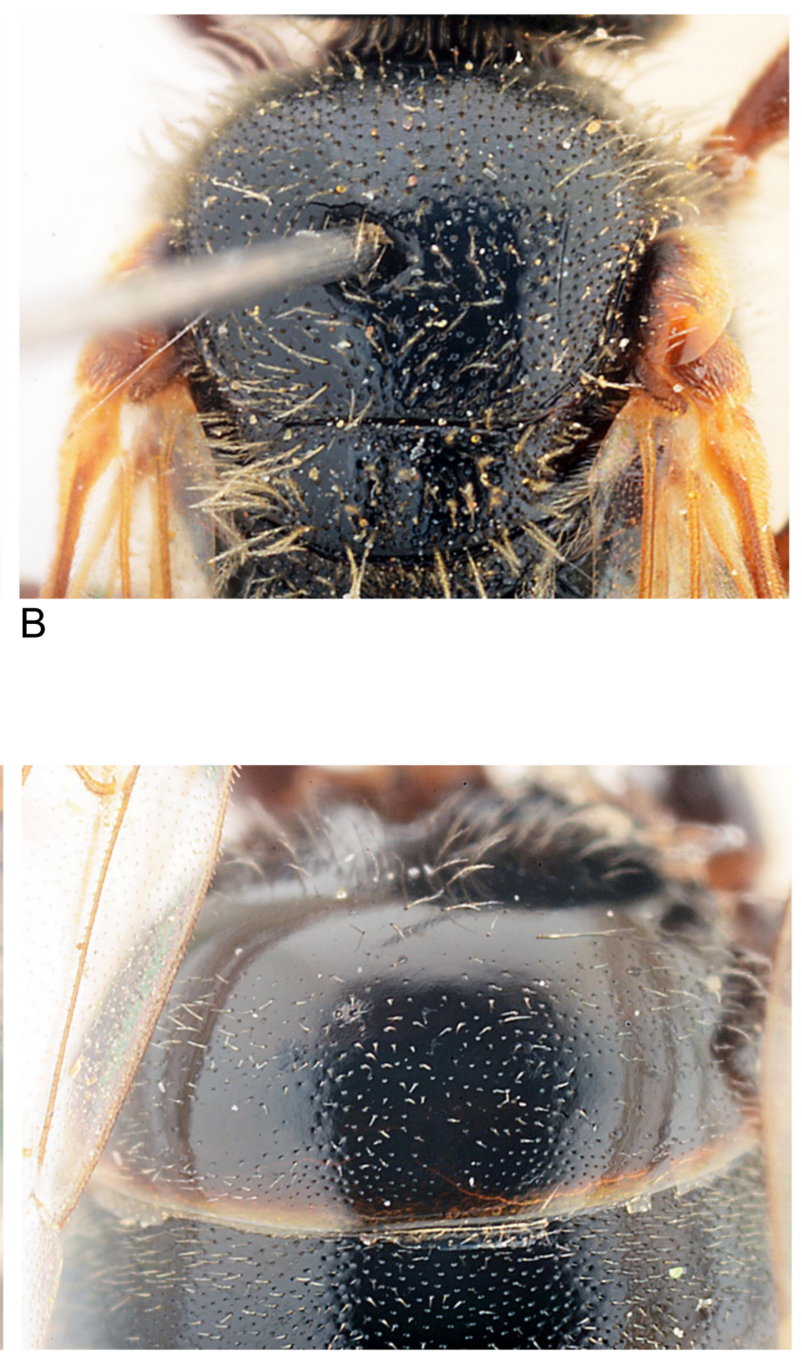

D

Fig. 10. Halictus villiersi Benoist, 1941, holotype, + . A. Head. B. Scutum. C. Propodeum. D. First tergum. E. Metasoma. 


\section{Halictus barkensis}

Blüthgen described this species as close to L. villosulum, but with a longer head. Ebmer (1974: 188; 1976: 253) considered L. barkense as a valid species occurring in Morocco (Grand Atlas), Libya, Israel and Turkey, but Warncke (1976: 94), Ebmer (1988: 649) and Pesenko (2007a: 41) considered it a synonym of $L$. villosulum.

\section{Halictus villiersi}

The type of $H$. villiersi is relatively small $(6 \mathrm{~mm})$, the punctation of the scutum is relatively dense and the propodeum is relatively well wrinkled. Ebmer (1974: 188; 1976: 253) considered L. villiersi as a synonym of $L$. barkense (Blüthgen, 1930) but Ebmer (1988: 649) reassessed it as a synonym of L. villosulum.

\section{Distribution}

Distribution (the asterisk * means that identification of specimens from that country has been confirmed in the current study): This subspecies is distributed throughout the western Palaearctic. Described from the United Kingdom, it is known from the Azores* (Weismann et al. 2017: 82), Madeira (Fellendorf et al. 1999: 4), Canary Islands (Warncke 1975b: 205), Spain* (including the Balearics*) (Ortiz-Sanchez \& Pauly 2017: 40), France* (including Corsica) (Pauly \& Belval 2017: 27), Belgium*, The Netherlands*, Luxemburg*, Germany*, Denmark (Rasmussen et al. 2016: 47), Norway*, Sweden (Svensson et al. 1990: 50), Finland* (north to $64^{\circ} \mathrm{N}$ ), Ireland*, Switzerland (Amiet et al. 2001: 150), Italy* (including Sardinia), Austria (Ebmer 1988: 649), Czech Republic and Slovakia (Pridal 2004: 40), Poland (Pesenko et al. 2000: 291), Slovenia (Gogala 1999: 19), Serbia*, Croatia*, Romania (Goaga 2003: 193), Bulgaria*, Greece* (including Crete*), Ukraine, Turkey (Warncke 1975a: 91), Israel* (Bytinsky-Salz \& Ebmer 1974: 188), Russia (Levchenko 2015: 17), Udmurtia (Pesenko 2007b: 113), Iran (Ebmer 1978c: 76), Afghanistan (Ebmer 1974: 200), India (Himashal Pradesh; Ebmer 2004: 131), Nepal (Ebmer 2004: 131), Morocco* (Ebmer, 1976: 253), Algeria*, Tunisia*, Libya (Blüthgen 1930: 224 ), Egypt (Blüthgen 1933: 19), Yemen* (Sanaa, Jebel Jaif). The subspecies occurs also in North America where it has been barcoded from Canada (British Columbia*) and USA (Washington State*) (Gibbs, pers. comm.).

Subspecies trichopse (Strand, 1914)

Synonymy (following Ebmer 1988: 649)

Halictus trichopsis Strand 1914: 156. Holotype: đิ, Taiwan, Taihorin, Jan. 1910 (SDEI). Not examined. Halictus melanomitratus Strand 1914: 156. Holotype: ㅇ, Taiwan, Taihorin, 7 Nov. 1910 (SDEI). Syn. by Blüthgen 1923: 241. Not examined.

Halictus melanomitratus var. mitratolus Strand 1914: 158. Holotype: + , Taiwan, Taihorin, Par. 1910 (SDEI). Syn. by Blüthgen 1923: 241. Not examined.

Halictus villosulopsis Blüthgen 1926: 540. Syntypes: 3 웅, Assam, Shillong, May 1903, leg. Turner (NHMUK013380276). Syn. by Ebmer 1978a: 207. Examined by DGN.

Halictus pahanganus Blüthgen 1928: 374. Holotype: $\widehat{\jmath}$, Malaysia, Lubok Tamang, cleared Hill, $4000 \mathrm{ft}$, Pahang, Federated Malay States, 10 Jun. 1923 (NHMUK013380277). Syn. by Ebmer 1978a: 207. Examined by DGN.

\section{Distribution}

This subspecies is distributed from East Himalaya, China (Ebmer 1978a: 207; 2006: 569), Mongolia (Ebmer 1982: 219; 2005: 378), Japan (Hokkaido: Usui et al. 1976: 228; Izu: Takahashi \& Sakagami 1993: 271, 275; Honshu: Haneda 1990: 8; Okinawa: Azuma \& Kinjo 1987: 314), North Korea (Ebmer 1978b: 315), South Korea (Murao 2017), south of Russian Far East (Primorsk Terr.: Ebmer 1996: 285, 2006: 569; Amur Prov.: Pesenko 2007b: 113), Taiwan and south to Malaysia (Fig. 11). It is not the 


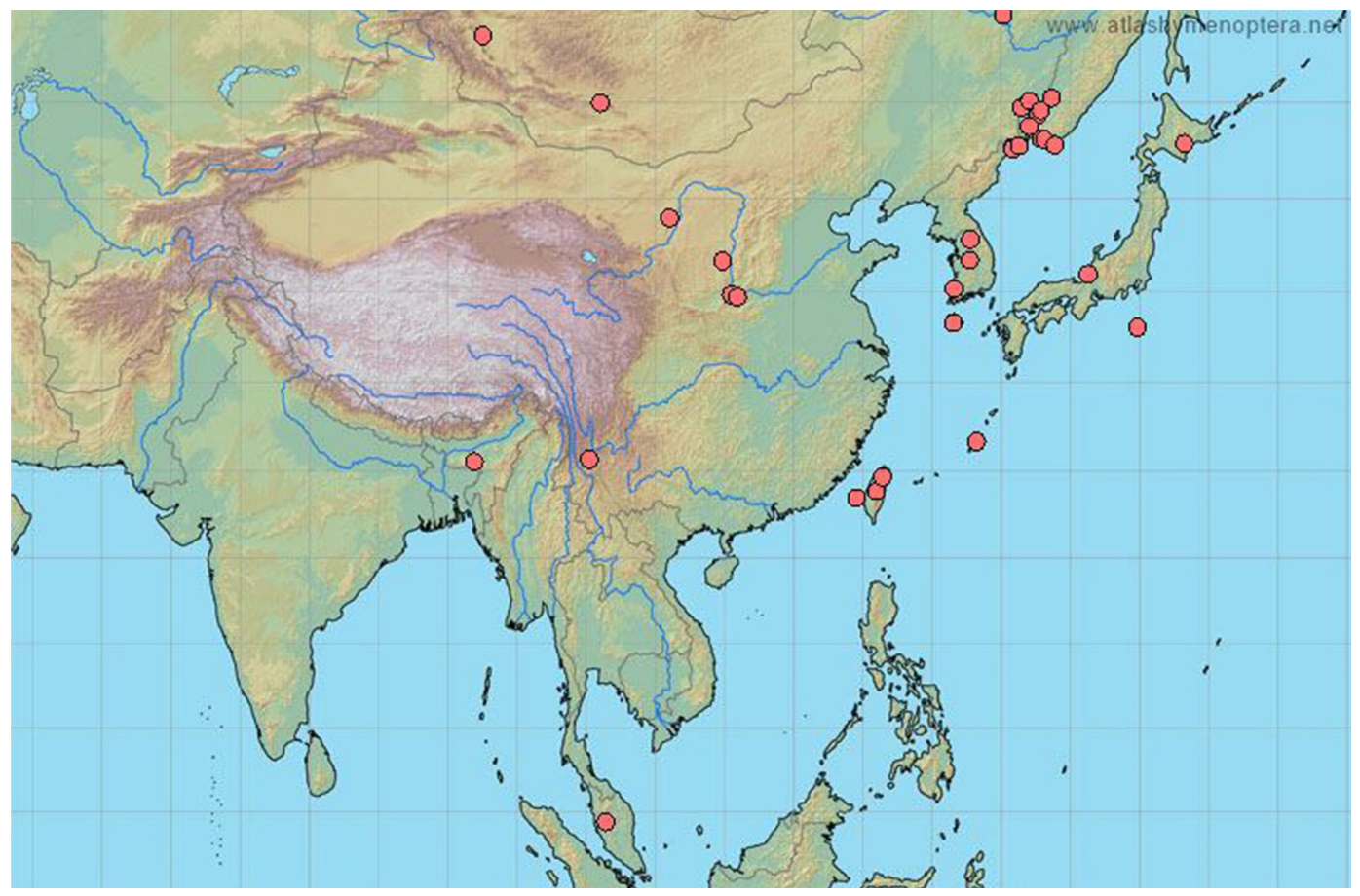

Fig. 11. Geographical distribution of Lasioglossum villosulum trichopse (Strand, 1914).

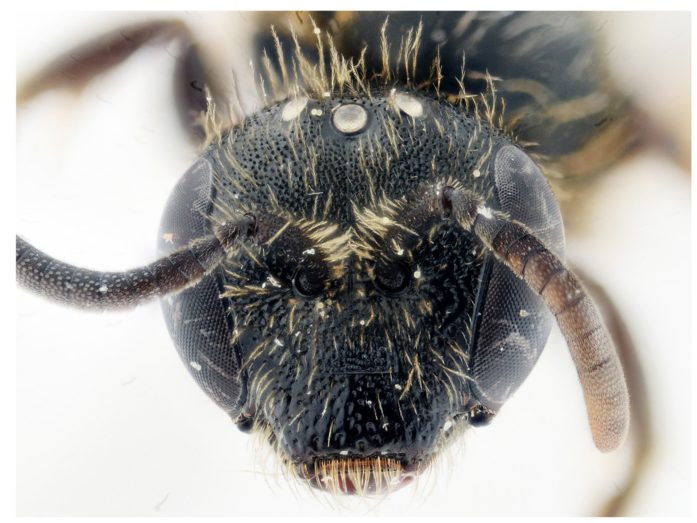

A
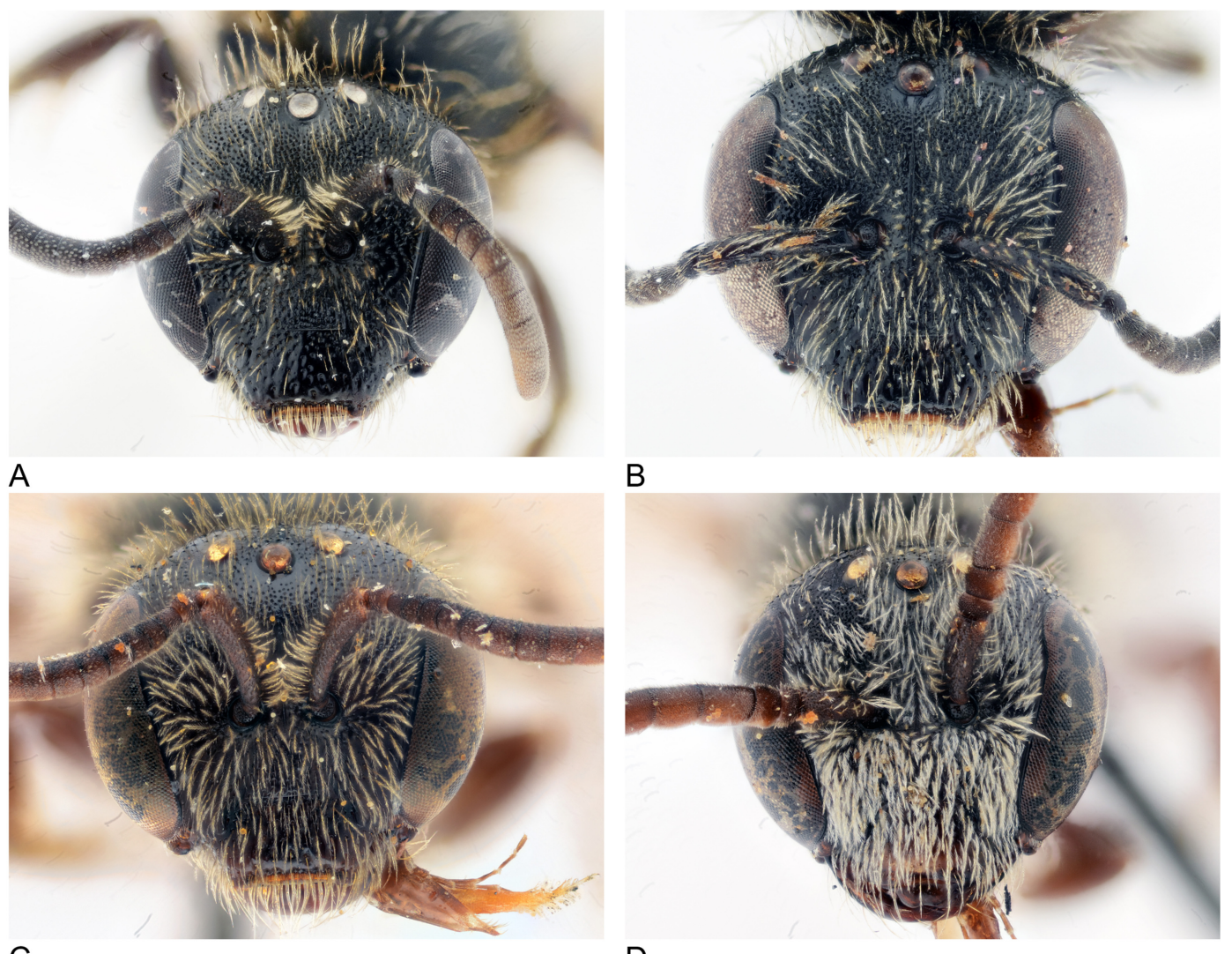

B

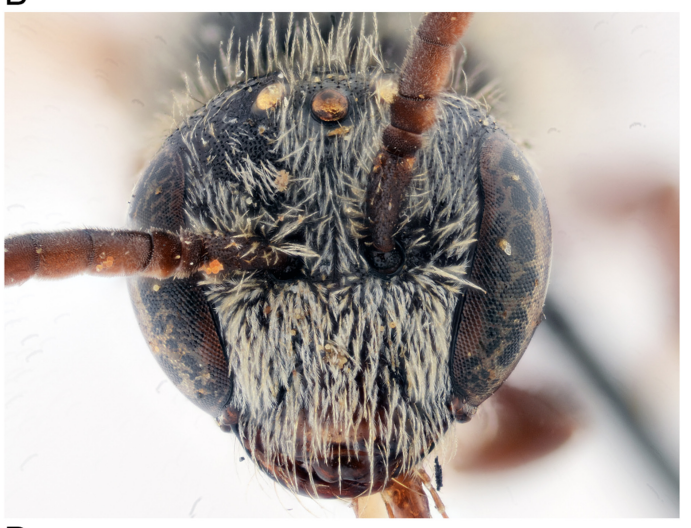

$\mathrm{D}$

Fig. 12. Heads. A. Lasioglossum villosulum villosulum (Kirby, 1802), q (France, Allier). B. L. medinai, $q$ (France, Vaucluse). C. L. villosulum trichopse (Strand, 1914), q (Taiwan). D. Idem, O̊. 
purpose of this paper to discuss the status and diagnosis of this subspecies, as little material is available for examination and no fresh material was available for DNA study. The subspecies is distinguished from the subspecies villosulum mainly by shorter and more rounded head and broader eyes. We have examined and photographed the heads of old specimens from the typical locality in Taiwan and preserved in the MNHUB and compared them with the heads of L. villosulum villosulum and L. medinai (Fig. 12). The punctation and genitalia of males are similar to those of L. villosulum.

Subspecies arabicum Ebmer, 2008

Lasioglossum (Evylaeus) villosulum arabicum Ebmer, 2008: 560. Holotype: + , UAE, Sharjah x Khor Kalba, 7-14 Jun. 2006, light trap, leg. A.V. Harten 6681 (SDEI). Examined by AP.

\section{Distribution}

This subspecies inhabits the Arabian Peninsula (Oman, UAE) and is distinguished mainly by red terga (Figs 13-14). Also conspicuous are the zones of snow white, felted, adpressed pubescence on the face, particularly on frontal area and pronotum, and white, felted, upstanding hairs on the mesopleura, particularly the front as well as the posterior propodeal surface and the lateral fields above. This pubescence marks the subspecies as a desert form (Ebmer 2008: 560; Dathe 2009: 385). Specimens from Oman and UAE have red terga, whereas those from Yemen, identified as L. villosulum by Ebmer (D. Notton, unpublished new record), have dark black terga. Maybe there is more taxonomic complexity here, but it is outside the scope of the current project to further examine this. It may correlate with topography and climate since Oman and UAE are generally lower altitude (hotter) and Yemen is generally higher altitude (cooler).

Lasioglossum medinai (Vachal, 1895)

Halictus medinai Vachal, 1895: 148. Holotype: đ̃, Spain, Sevilla, “col. Medina” (MCSN), examined. Blüthgen 1923: 239 (syn. of H. villosulus). Examined by AP.

\section{New diagnosis}

Morphological examination of the type of Halictus medinai confirms that this large specimen belongs to the cryptic species. Its size is $7 \mathrm{~mm}$ (Fig. 2C-D), the punctation of the scutum is denser than in L. villosulum. Head, punctation of the scutum, sculpture of propodeum and punctation of terga of the male holotype are illustrated (Fig. 15).

Morphological examination of the females makes it possible to note immediately, in addition to a larger body size $(7 \mathrm{~mm})$, the denser punctation of the scutum (Fig. 16) as well as the stronger wrinkles of the propodeum, which reach the posterior edge (Fig. 17). In most cases, we can verify the identification using two more subtle characters:

(1) the punctation of the tergum 1 is much more superficial in the middle and on the apical margin, absent in the middle of the apical margin, whereas in L. villosulum the punctation of the tergum 1 is deeper and the apical margin is punctuated even in the middle (Fig. 18).

(2) a small unpunctuated area in front of the larger anterior ocelli, more extended than in L. villosulum, and punctation around this area finer (Fig. 19).

Morphological examination of a single male of $L$. medinai obtained by breeding and from Uchaux confirms that males of this species also have denser punctation on the scutum. The genitalia of several large males with denser punctation of the scutum and collected at the same time as females of L. medinai show only very subtle differences which may be characteristic (Fig. 20): 

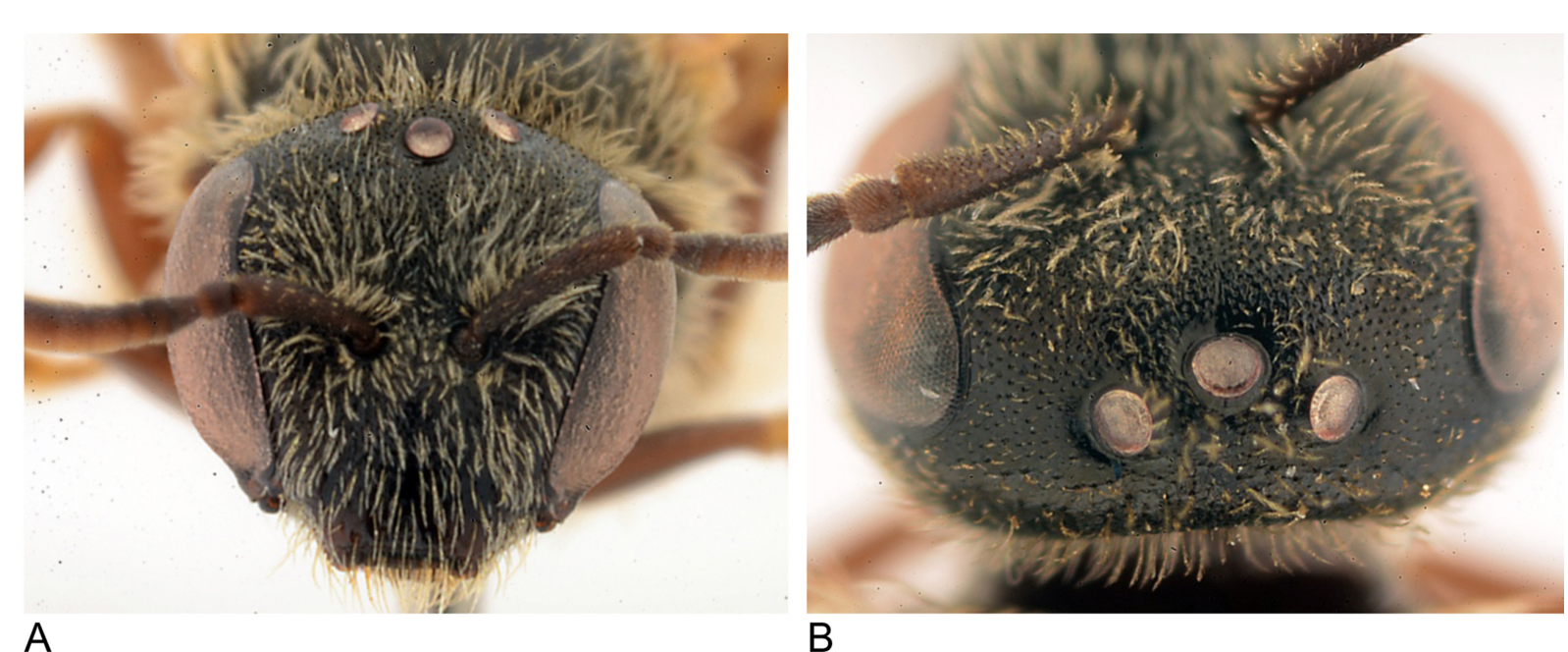

B
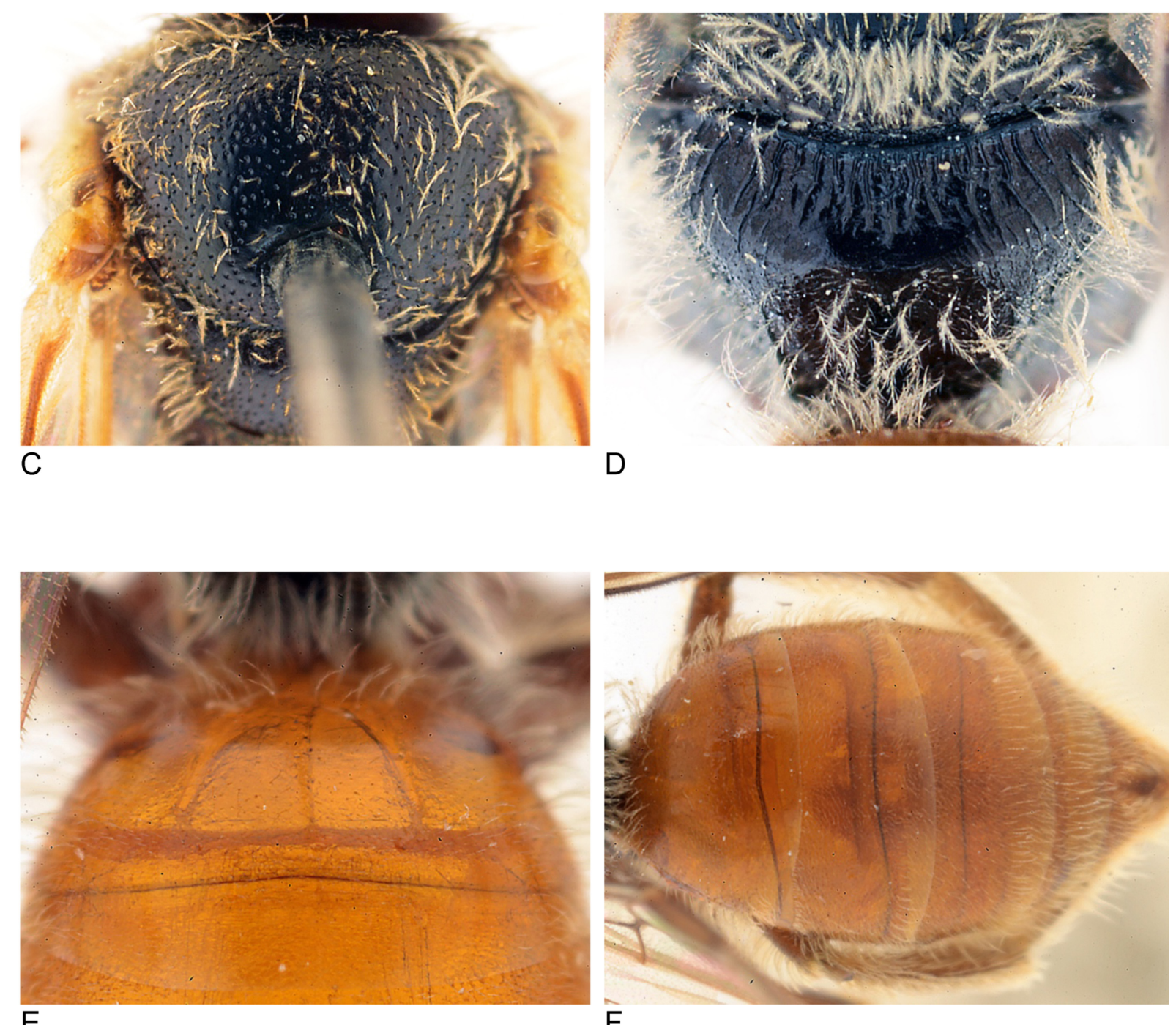

$\mathrm{F}$

Fig. 13. Lasioglossum villosulum arabicum Ebmer, 2008, $q$ (UAE). A. Head. B. Punctation around ocellus. C. Scutum. D. Propodeum. E. First tergum. F. Metasoma. 


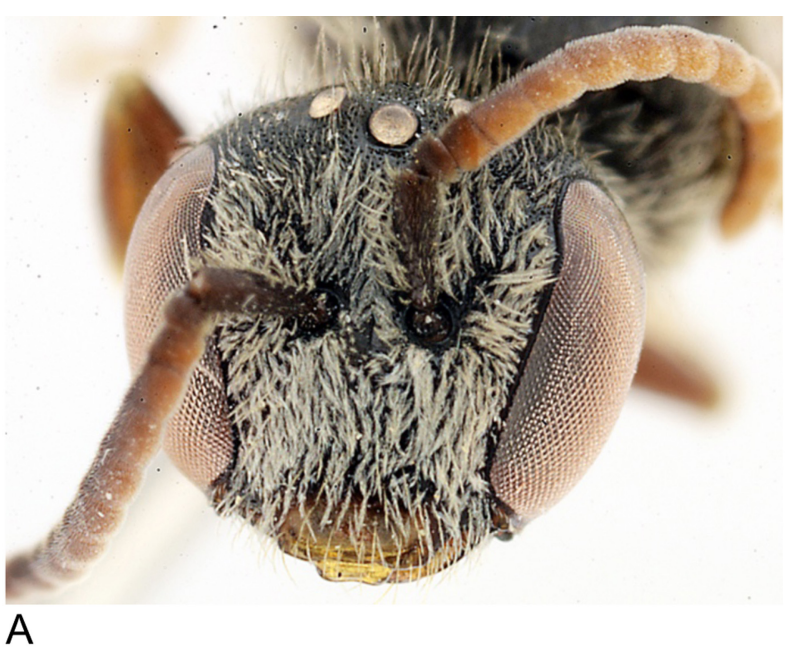

A

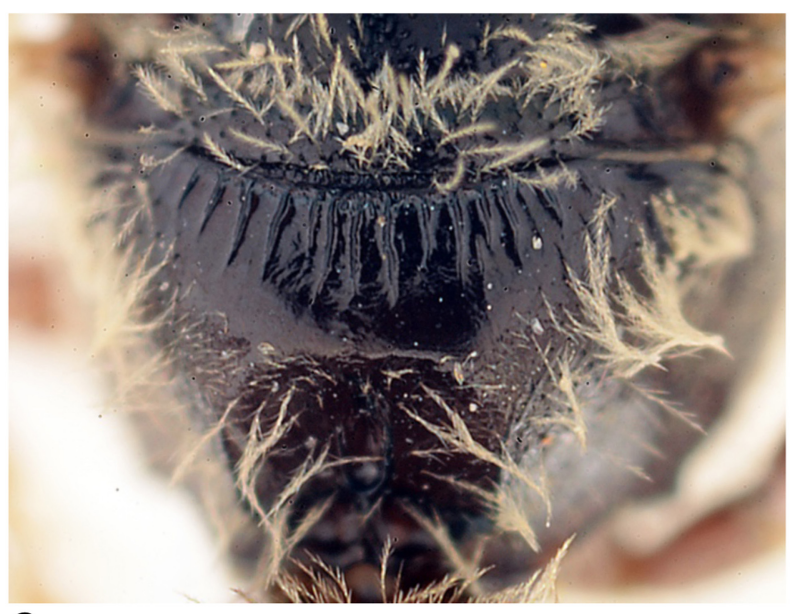

C

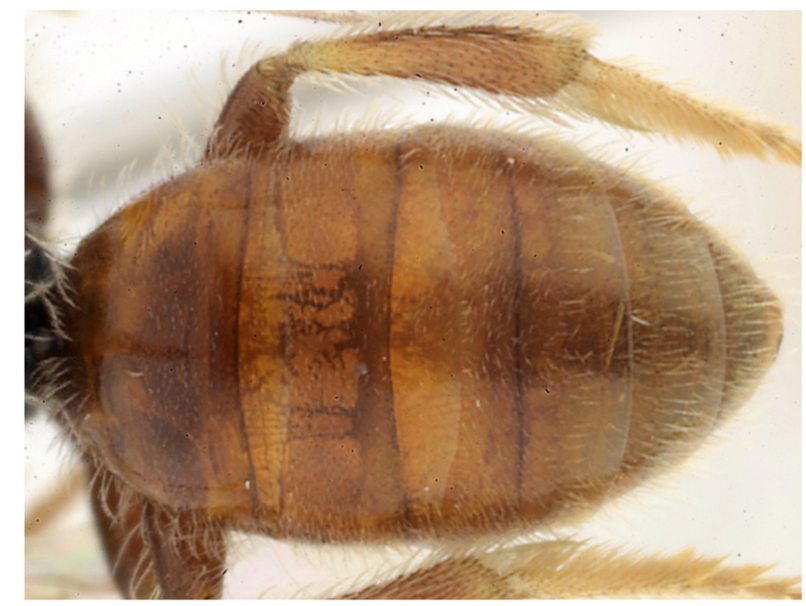

E

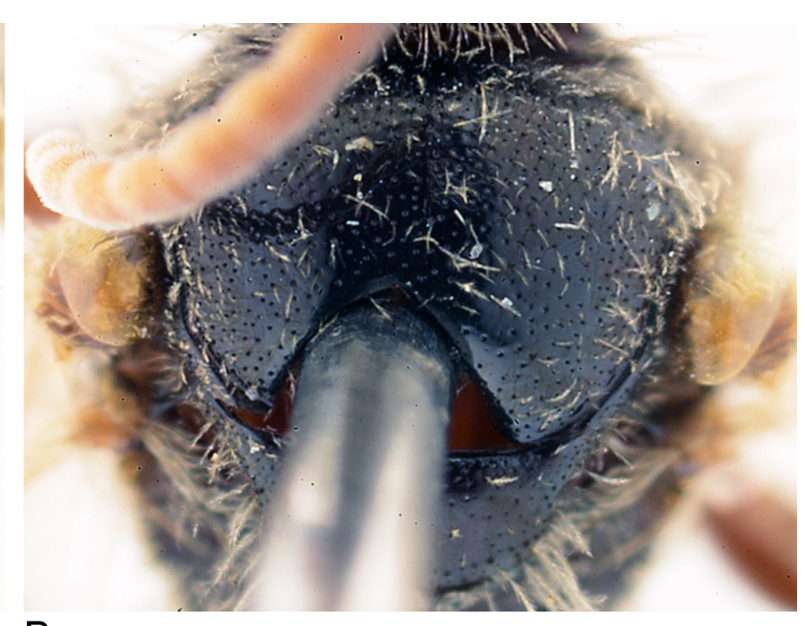

B

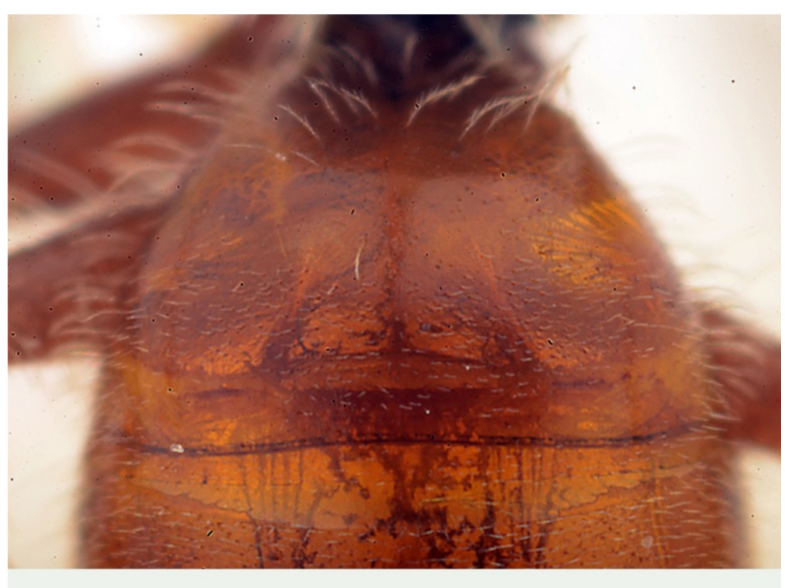

D

Fig. 14. Lasioglossum villosulum arabicum Ebmer, 2008, §̊ (UAE). A. Head. B. Scutum. C. Propodeum. D. First tergum. E. Metasoma. 
- L. medinai: reflexed gonostylus lobe with apex blunt (Fig. 20Cb), outer hind corner more produced (Fig. 20Ca); gonostylus in line with axis of gonocoxite (Fig. 20Cc).

- L. villosulum: reflexed gonostylus lobe with apex more tapered, outer hind corner less produced; gonostylus directed inwards relative to axis of gonocoxite.

Also, in L. medinai the bristles of the last sterna form a slightly thicker fringe (Fig. 21).

\section{Material examined}

The following specimens of Lasioglossum medinai were identified by morphology (the asterisk * indicates the specimens selected for barcoding); countries are mentioned from west to east and from north to south:

SPAIN - Cadiz • 2 q *; Jerez de la Frontera, 29SQA541660; 40 m; 29 Mar. 2009; J. Ortiz-Sanchez leg.

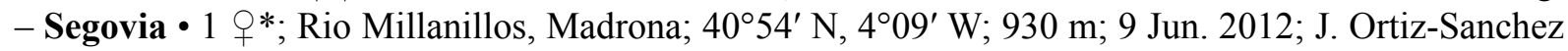
leg. - Albacete • 1 क; Caserio zapateros, Sa Alcaraz, 30SWH44468; 1150 m; 23 Apr. 2005, F.J. OrtizSanchez leg. - Cordoba • 3 q $ᄋ$; Fuente Obejuna, 30STH7940; 600 m; 26 Apr. 2009; J. Ortiz-Sanchez leg. - Badajoz • 1 q; Badajoz, 29SPD7209; 200 m; 25 Apr. 2009; J. Ortiz-Sanchez leg.

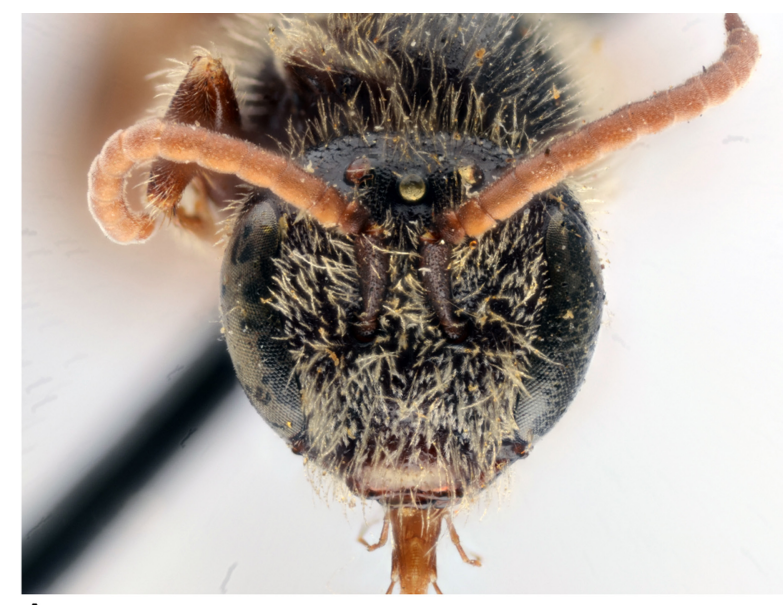

A

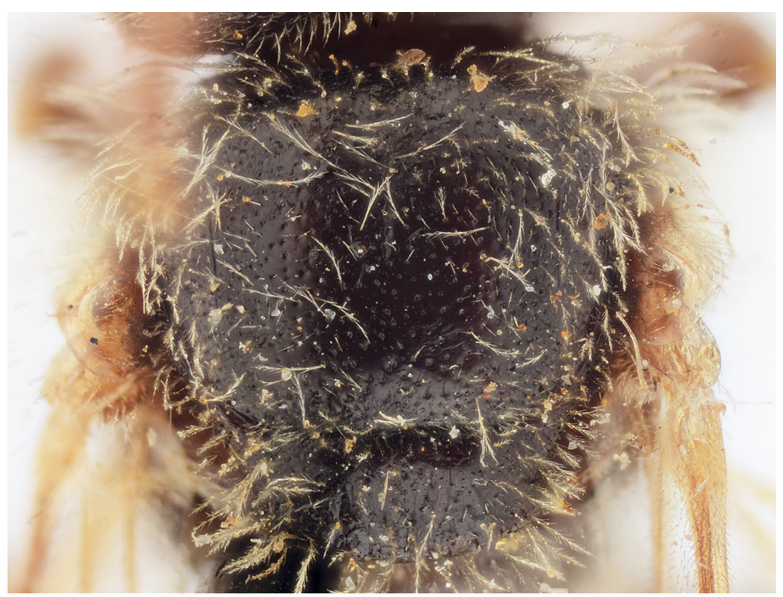

B

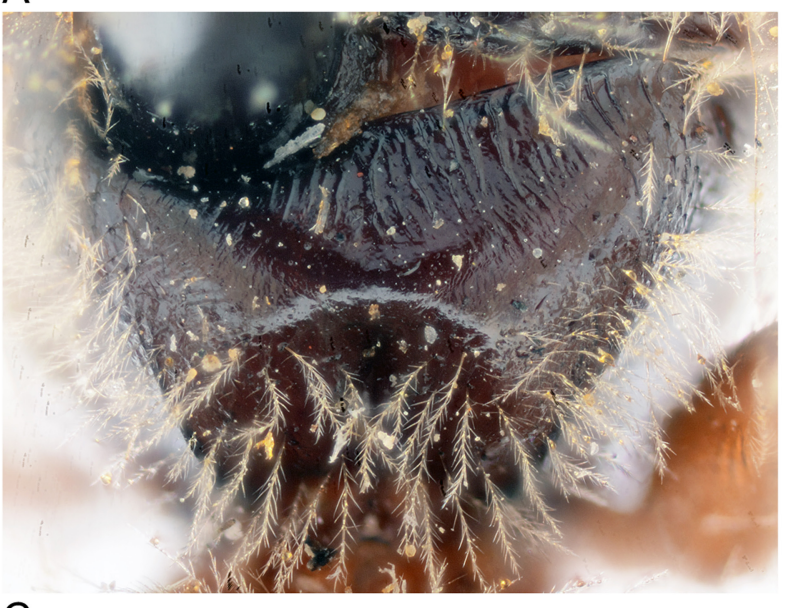

C

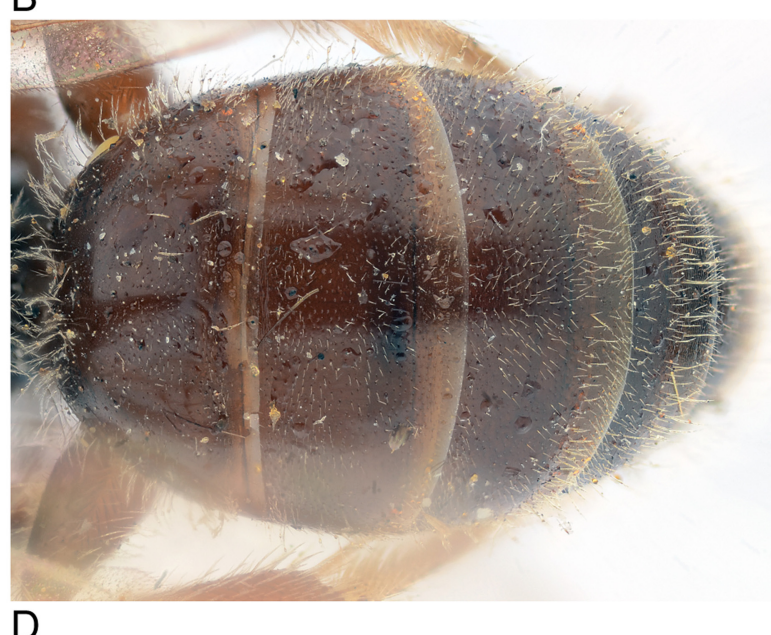

Fig. 15. Lasioglossum medinai (Vachal, 1895), holotype, §̂. A. Head. B. Scutum. C. Propodeum. D. Metasoma. 


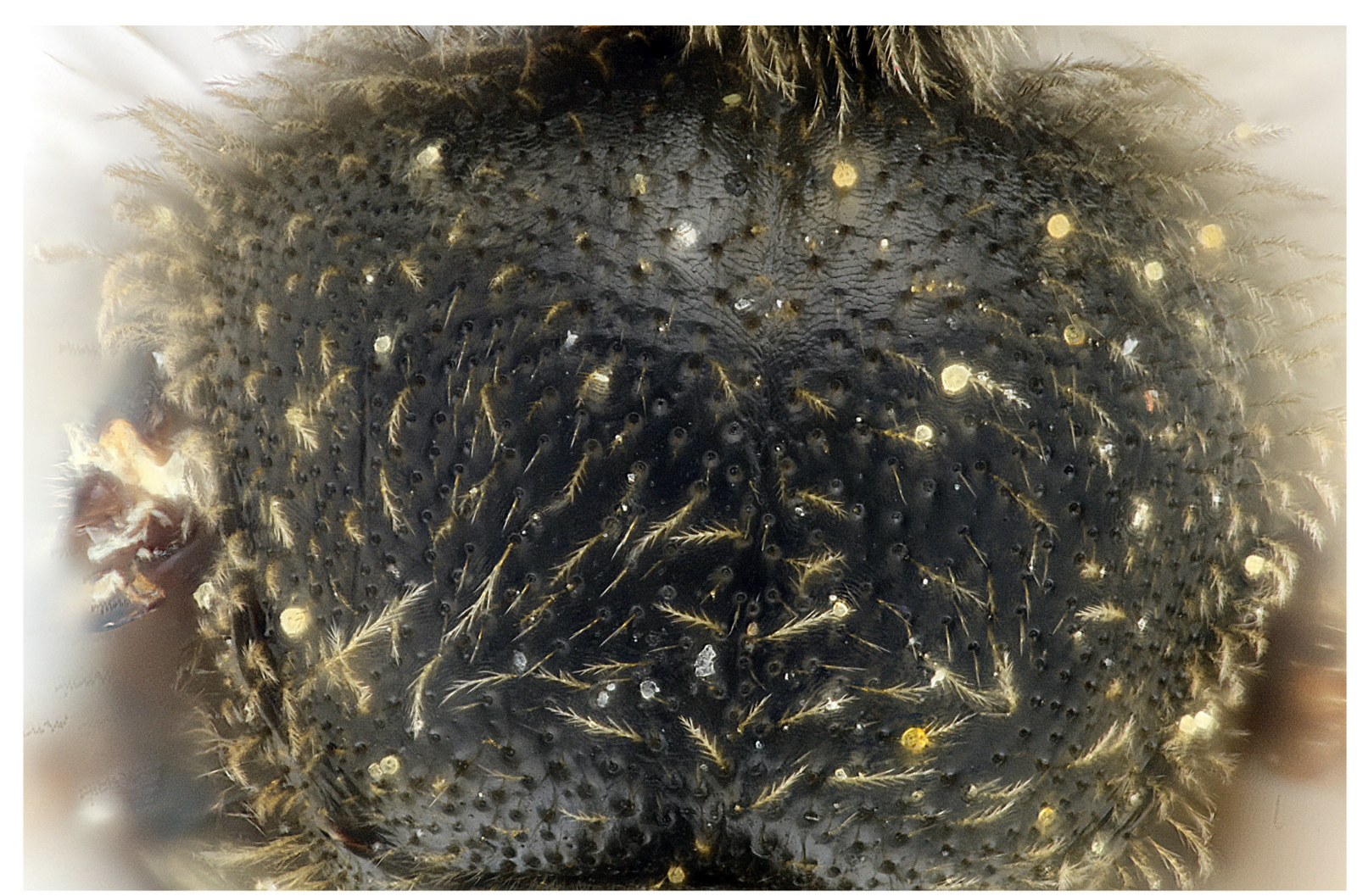

A

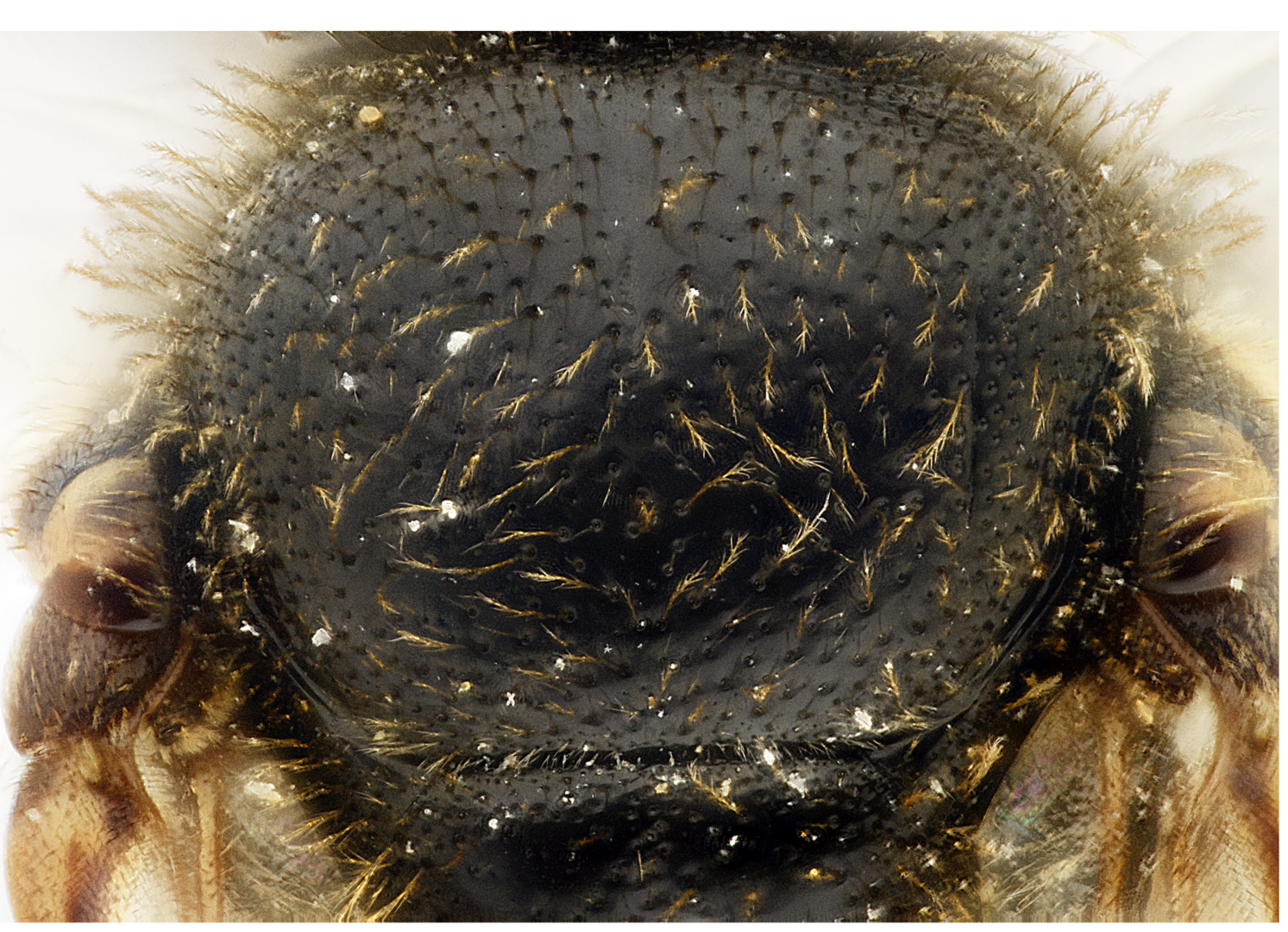

B

Fig. 16. Punctation of the scutum of females. A. Lasioglossum medinai (Vachal, 1895) (France: Uchaux). B. L. villosulum (Kirby, 1802) (Belgium: Bruges). 


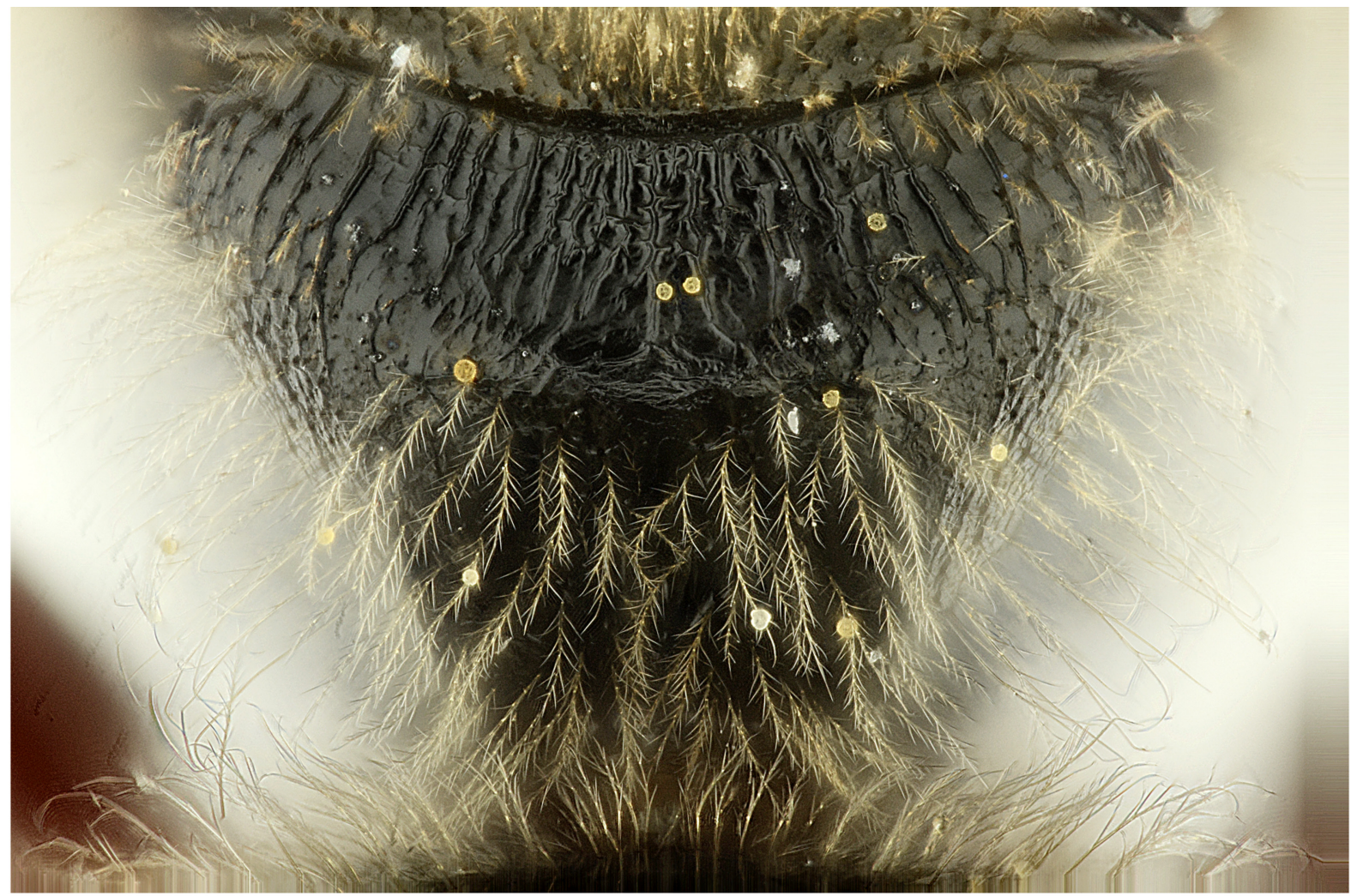

A

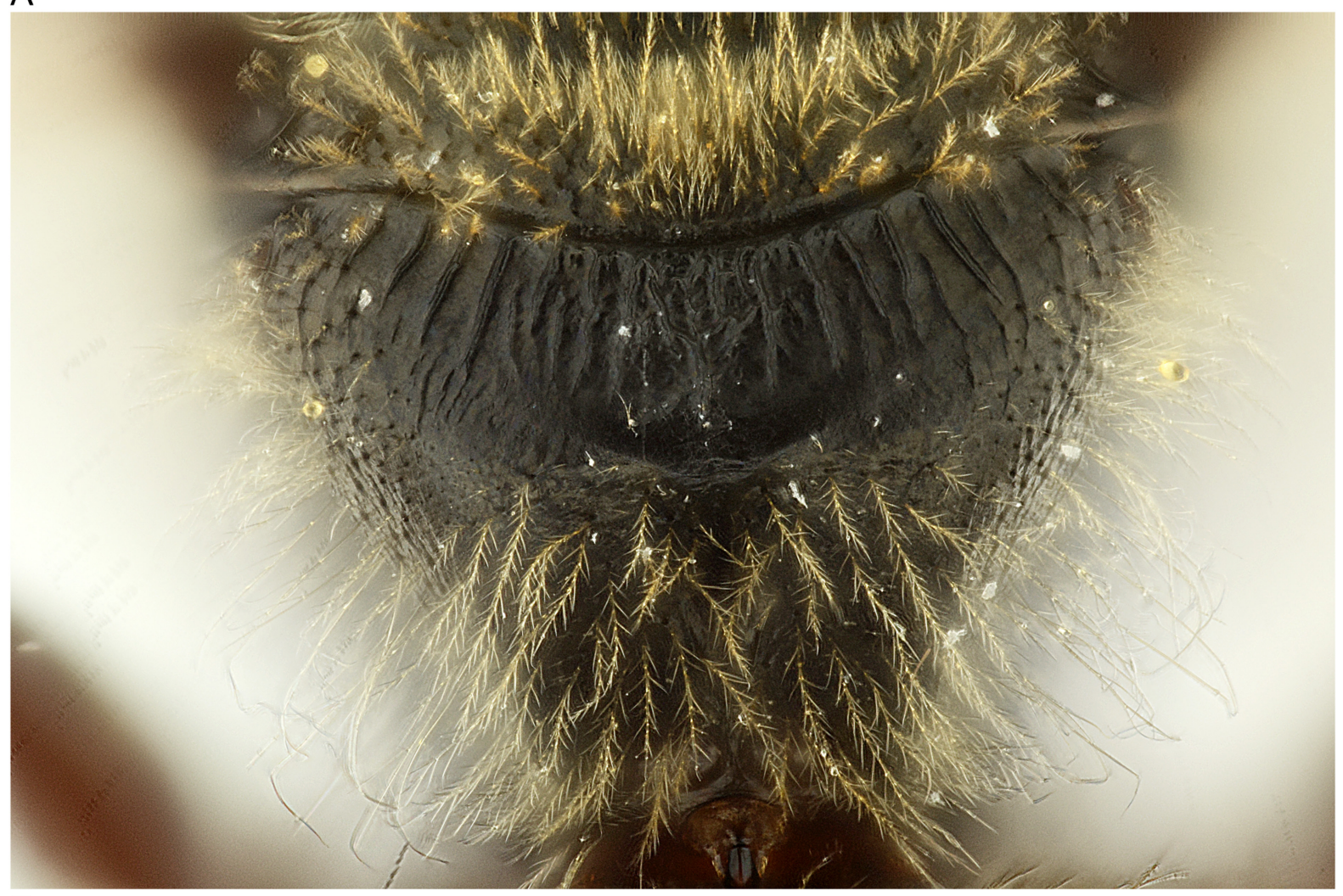

B

Fig. 17. Propodeum sculpture of females. A. Lasioglossum medinai (Vachal, 1895) (France: Uchaux). B. L. villosulum (Kirby, 1802). 

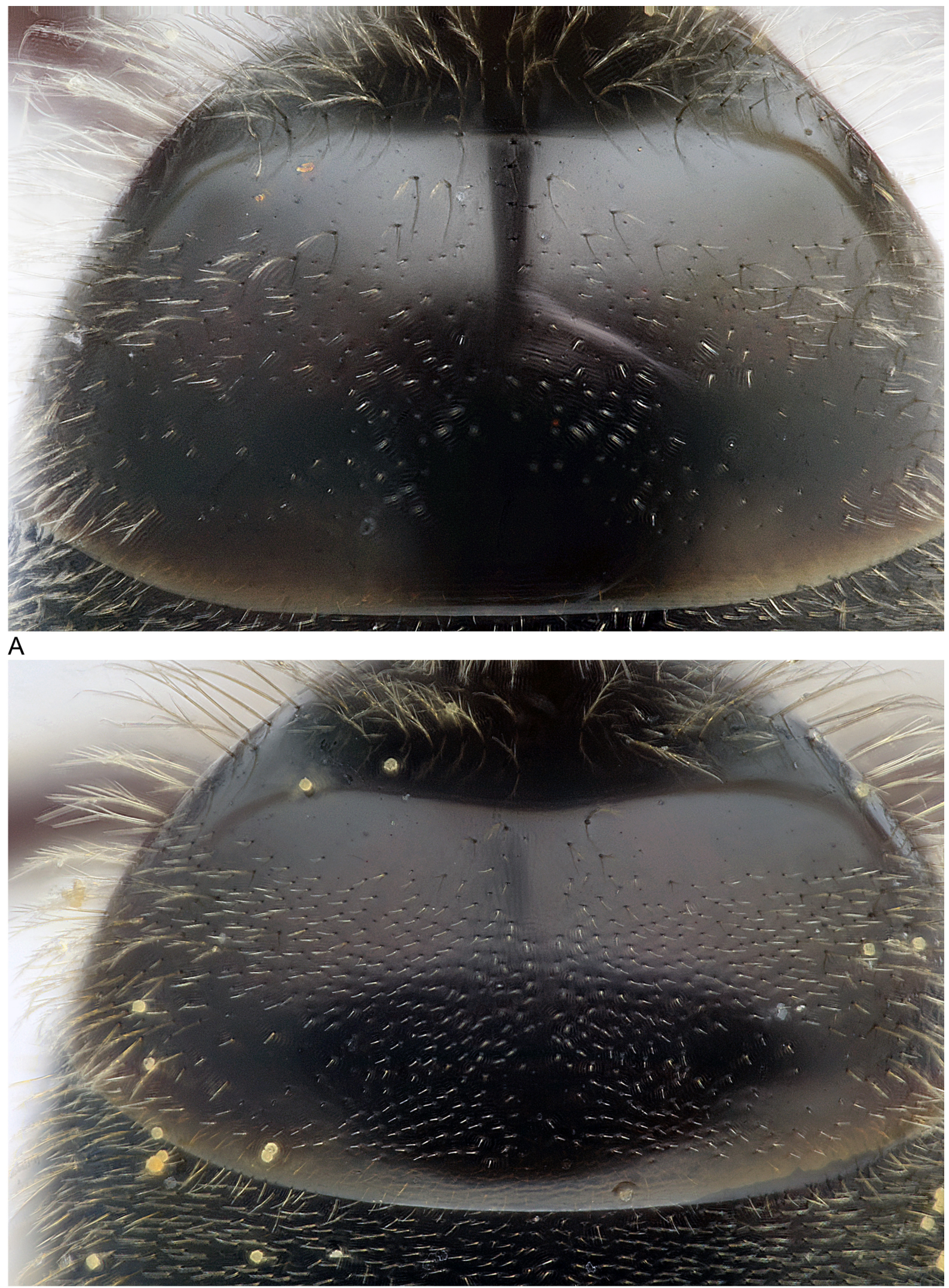

B

Fig. 18. Punctation of the first tergum of females. A. Lasioglossum medinai (Vachal, 1895) (France: Uchaux). B. L. villosulum (Kirby, 1802) (France: Visan). 


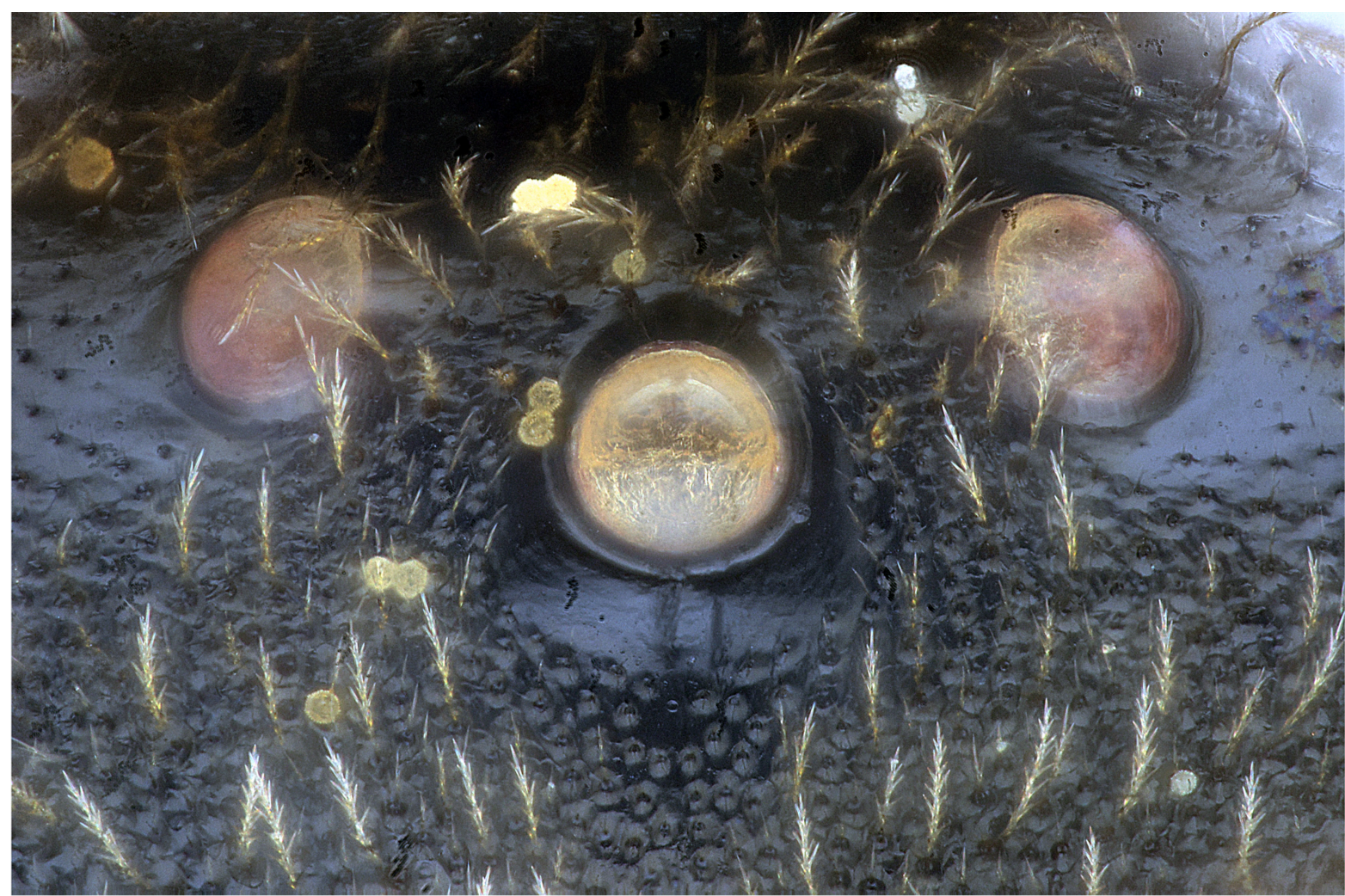

A

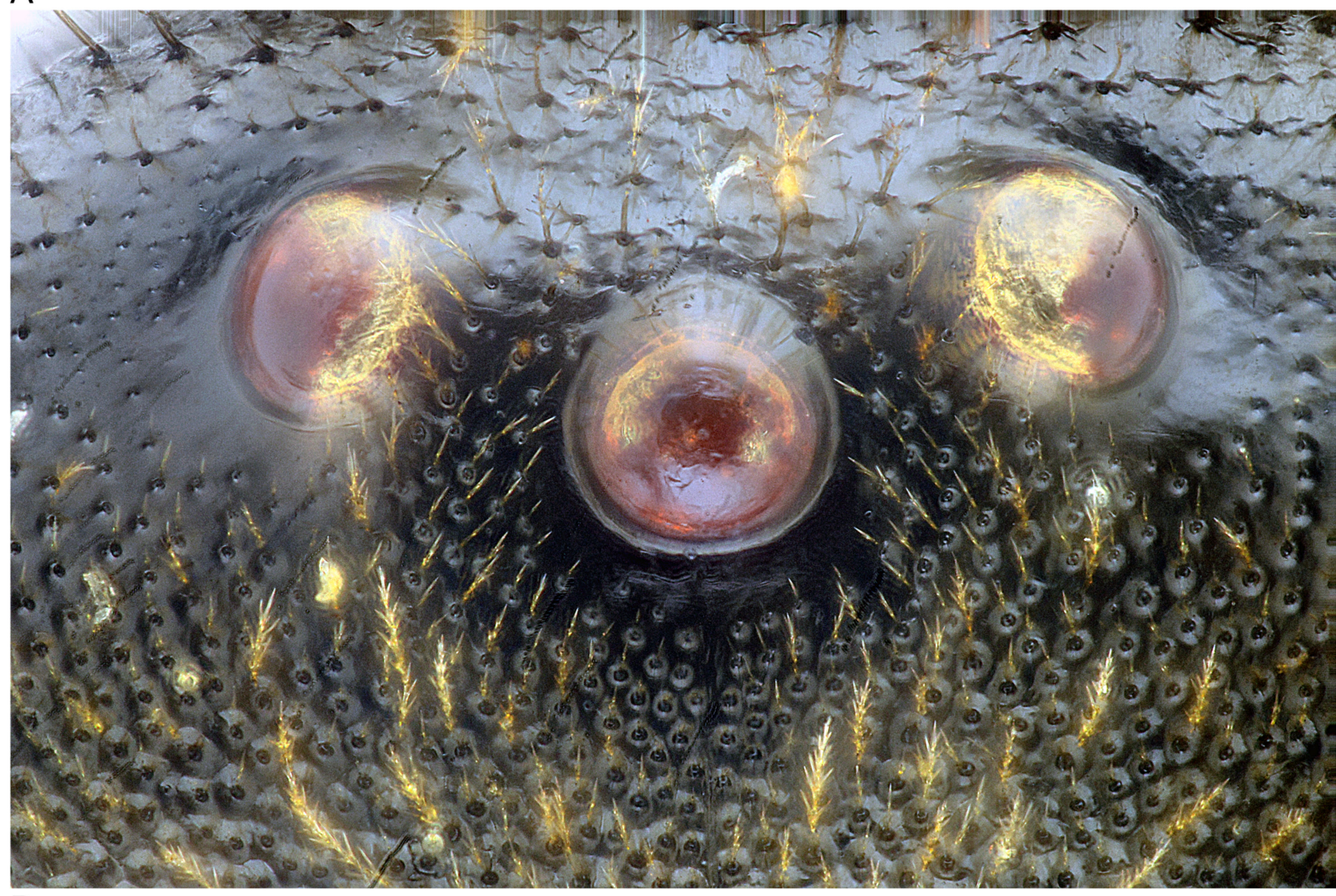

B

Fig. 19. Punctation in front of the medial ocellus of females. A. Lasioglossum medinai (Vachal, 1895) (France: Uchaux). B. L. villosulum (Kirby, 1802) (Luxembourg: Stadtbredimus). 
FRANCE - Alpes-de-Haute Provence 1 \%; Manosque S of 4.2 km; G. Carré leg.; INRA • 2 q ;

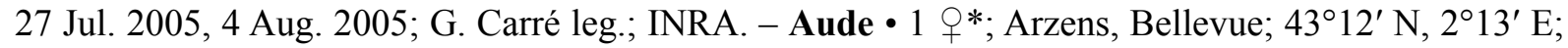
10 May 2014; D. Genoud leg. et coll. 1 O*; Saint-Marcel-sur-Aude, Le Four à Chaux; 17 Apr. 2014; D. Genoud leg. et coll. - 1 क; Pennautier; 11 Apr. 2015; on Brassica napus; O. Rollin leg.; INRA.

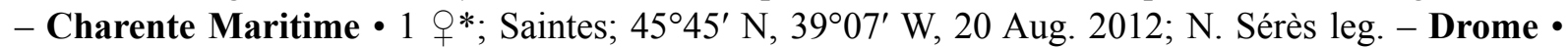
1 *; Saint-Gervais-sur-Roubion; 44³4' N, 453' E; 31 Jul. 2007; G. De Prémorel leg.; from crop of Helianthus annuus; INRA - 1 \%; Marsanne; 28 Jul. 2007; on Helianthus annuus; INRA. - Gard - 1 क ; Etang du Ponant; 22 Apr. 1980; GABT. - Eure • 1 क ; Falaise-Giverny; 4904' N, 133' E; 18 May 2017; N. de Manincor leg.; nFAL-1302. - Gironde - 1 ○*; Lacanau, Cousseau; 5 May 2013; S. Labatut leg. (D. Genoud coll.). - Loir and Cher • 1 \%; Selommes; 19 Apr. $2007 \bullet 1$ \%; 25 Apr. 2007 • 1 q; 25 Apr. 2007; NHMUK 013380274 • 1 \%; 29 Apr. 2007; RBINS • 1 \%; 30 Apr. 2007; R. Chifflet

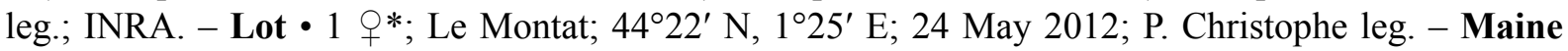
and Loire 1 \&*; Cléré-sur-layon, La Paguerie, XT9518; 25 Apr. 2013; O. Durand leg. - Pyrénées Orientales $\bullet 2$ 우; Perpignan; 10 Apr. 1970; A. Pauly leg.; RBINS • 2 $q$; ; Canet; Apr. 1893; NHMUK 013380289, 013380290. - Rhône • 1 \%*; Lyon; 4546' N, 447’ E; 20 Jun. 2011; L. Motino leg.; INRA • 1 क; Lyon; 16 Apr. 2013; INRA • 1 q; Villeurbanne; 15 Sep. 2010; L. Neu leg.; INRA • 1 q; Crépieux; 19 Apr. 2011; L. Fortel leg.; INRA・1 $\odot$; Meyzieu; 29 May 2010; L. Neu leg.; INRA. - Vaucluse • 14 $\odot$; Uchaux; 18 Apr. 1992; L. Plateaux and C. Plateaux-Quénu leg. et coll. 1 \%; Bollène; 22 Apr. 1979;

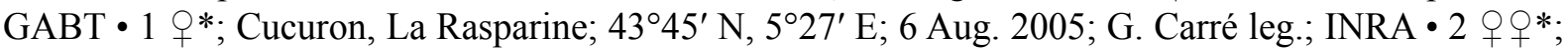
La Tour d'Aigues, St Victor; 2 Aug. 2005; G. Carré leg.; INRA • 3 q $q * ; 10$ Aug. 2005; G. Carré leg.; INRA • 1 क; La Motte d'Aigue, La Pavine; 16 Jul. 2004; R. Chifflet leg.; INRA • 1 ô, 12 우; $30 \mathrm{Jul}$. 2004; same collection data as for preceding; INRA 1 \%; same collection data as for preceding; RBINS • 6 + $q$; 6 Aug. 2004; same collection data as for preceding; INRA 1 1 ; same collection data as for preceding; NHMUK 013380273 • 1 ઈ, 2 우; Uzès, Mas Marsau; 1 Aug. 2005; G. Carré leg.;

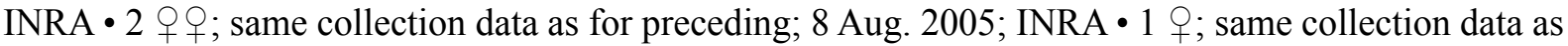
for preceding; 15 Aug. 2005; INRA $\bullet 1$ q; same collection data as for preceding; 22 Aug. 2005; INRA - 2 o 9 ; Saint Jean de Maruejol, Mas Imbert; 1 Aug. 2005; G. Carré leg.; INRA • 2 qq; Cucuron, La Rasparine; 6 Aug. 2005; G. Carré leg.; INRA • 1 q; same collection data as for preceding; 16 Aug. 2005; G. Carré leg.; INRA • 1 q; Villelaure, Versailles; 6 Aug. 2004; R. Chifflet leg.; INRA ・ 1 O , 6 q ; same collection data as for preceding; $30 \mathrm{Jul}$. 2004; R. Chifflet leg.; INRA 1 1 ; ; same collection data as for preceding; RBINS • 1 क; Villelaure, Saint Pierre; 2 Aug. 2005; G. Carré leg.; INRA • 5 q $ᄋ$; Villelaure, St Marc; 30 Jul. 2004; R. Chifflet leg.; INRA • 8 q ; same collection data as for preceding; 6 Aug. 2004; R. Chifflet leg.; INRA • 1 q; Velleron, La Mourelette; 26 Jul. 2002; B. Vaissière leg.; INRA - 2 우; Lourmarin, La Haute Prairie; 16 Jul. 2014; R. Chifflet leg.; INRA • 4 우; same collection data as for preceding; $30 \mathrm{Jul}$. 2004; R. Chifflet leg.; INRA • 8 qक; same collection data as for preceding; 6 Aug. 2004; R. Chifflet leg.; INRA • 1 क; Montfavet, St Maurice; 27 Jul. 2002; on Lactuca serriola; B. Vaissière leg.; INRA.

ITALY - Lazio • 1 q; Gallinaro; 19-20 Jul. 1983; R. Wahis leg.; GABT. - Campania • 1 q; Caserta; Apr. 1895; NHMUK 013380288. - Veneto - 2 o $\circ$; Laguna Veneta; 1944; Soika leg.; NHMUK 013380299,013380300 .

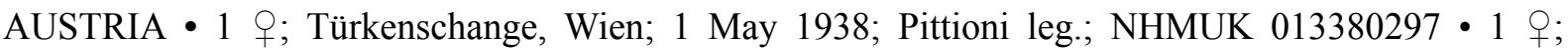
Stammersdorf; 8 May 1946; NHMUK 013380302 • 1 क; same collection data as for preceding; 19 May 1946; NHMUK 013380301.

ROMANIA• 1 ㅇ; Dobrogea, Macin; Montadon leg.; NHMUK 013380292.

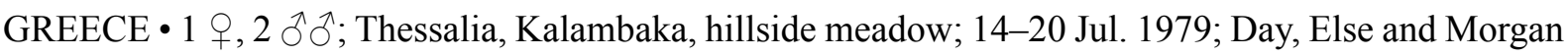
leg.; NHMUK 013380281, 013380762, 013380763 • 1 q; Old Lefkas, Lefkas; 25 Apr. 1977; Guichard 


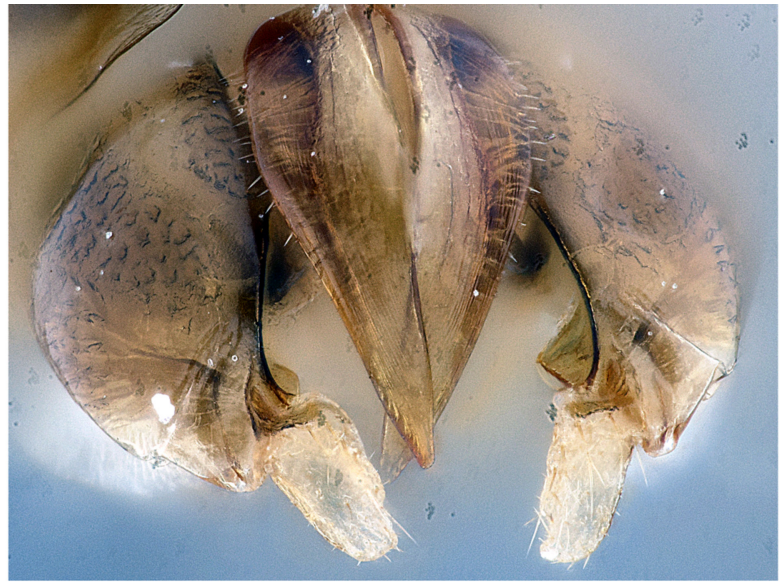

A

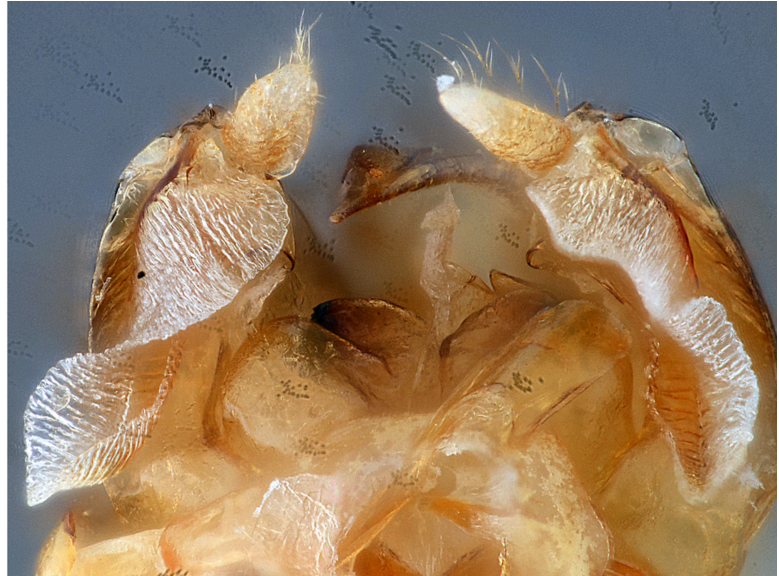

B

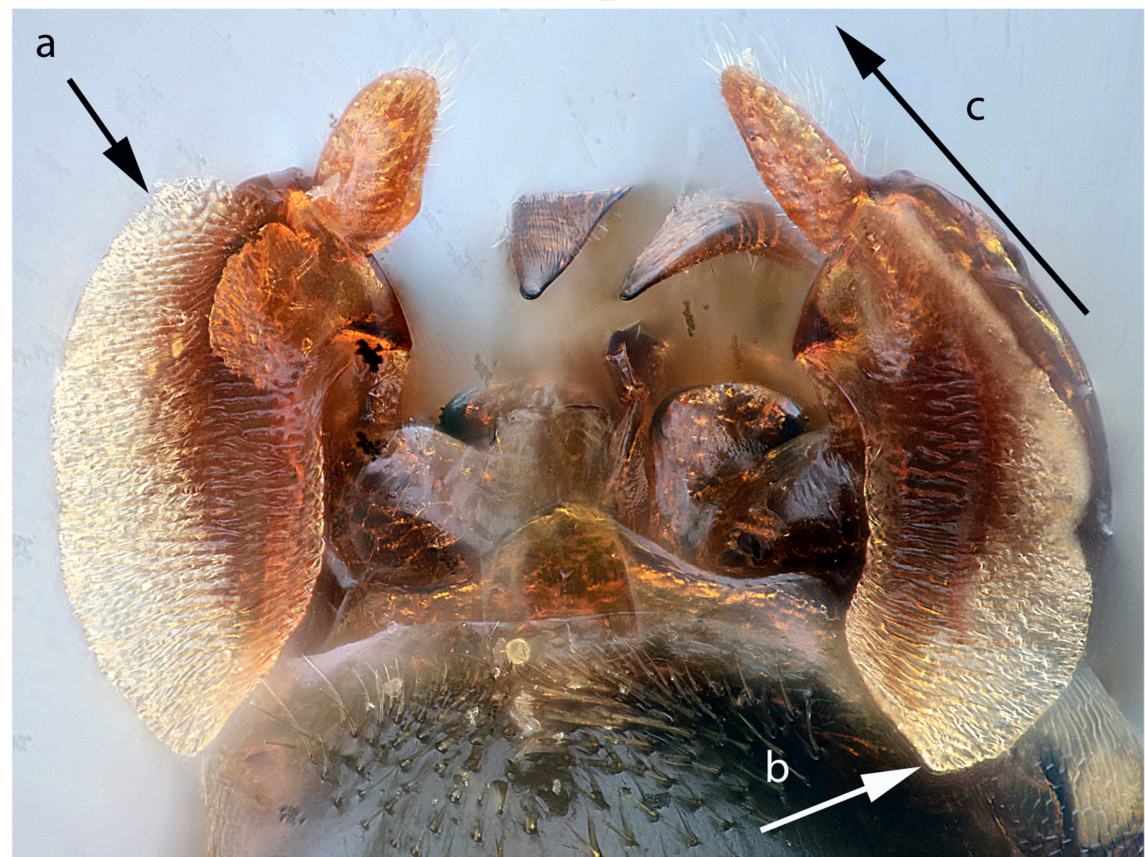

C

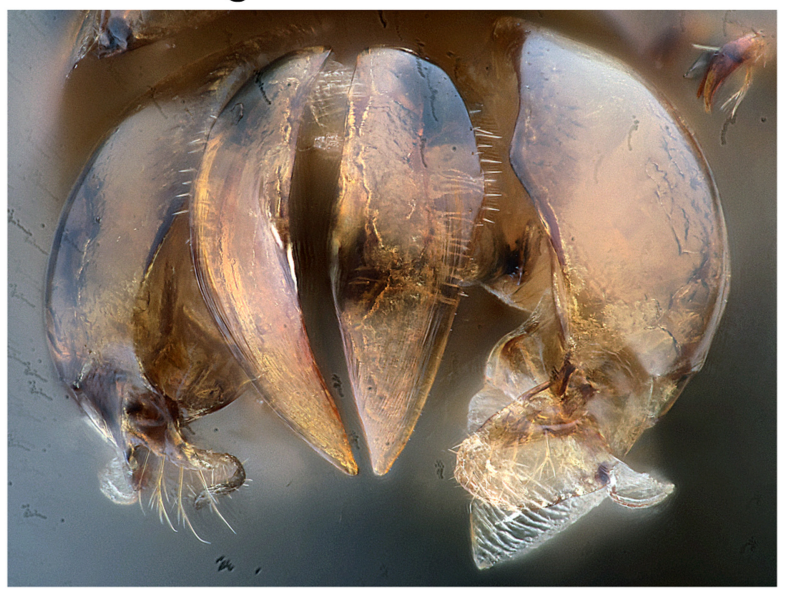

$\mathrm{D}$

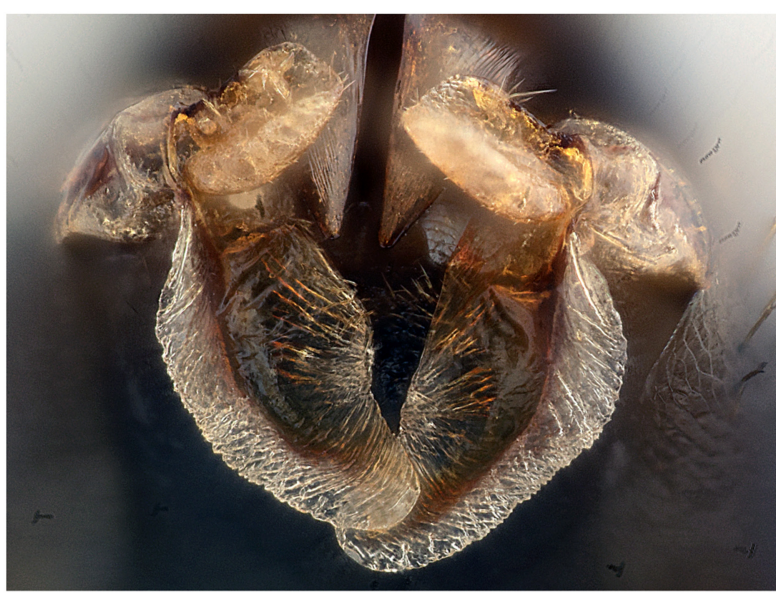

$\mathrm{E}$

Fig. 20. Male genitalia in dorsal and ventral views. A-B. Lasioglossum medinai (Vachal, 1895) (France: Alpes de Haute-Provence, Manosque). C. L. medinai (Greece: Thessalia, Kalambaka) (explanation of arrows in the text). D-E. L. villosulum (Kirby, 1802) (Belgium). 
leg.; NHMUK 013380283 • 1 क; Ilia, Olympia; 4 Jul. 1979; Day, Else and Morgan leg.; NHMUK

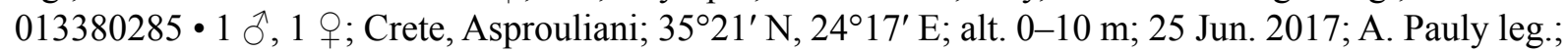
RBINS.

CYPRUS • 2 q 9 ; Limassol; Feb. 1934; Mavromoustakis leg.; NHMUK 013380293, 013380294 • 1 क; Nicosia; 15 Apr. 1971; K. Guichard leg.; NHMUK 013380295 • 1 क; Larnaca; 17 Mar. 1971; K. Guichard leg.; NHMUK 013380296.

RUSSIA • 1 q; Michailowka [? = Mikhailovskaya]; 3 Oct. 1942; NHMUK 013380303.

ALGERIA • 1 \%*; Biskra, Tolga; 3443' N, 5²3’ E; 23 Mar. 2011; H. Djouama leg. et coll.

ISRAEL • 1 \%*; Judean foothills, Mevo Horon; $31^{\circ} 52^{\prime}$ N, $35^{\circ} 02^{\prime}$ E; 7 Jun. 2011; Y. Mandelik leg.; HUJ 80871.

\section{Distribution (Fig. 22)}

Lasioglossum medinai is a sub-Mediterranean species, occurring in Spain, France, Italy, Austria, Romania, Greece (including Crete), Turkey, Cyprus and North Africa to Israel. There was no evidence of L. medinai in Britain (DGN).

\section{Lasioglossum berberum (Benoist, 1941)}

Halictus berberus Benoist, 1941: 81. Holotype: đ̊. Morocco, Dj M'Goum, 3200 m, 1-15 Sep. (MNHN). Examined (AP) (Fig. 23).

\section{Remarks}

Ebmer (1976: 251; 1988: 649) considers this species as valid, but Pesenko (2007a: 41) following Warncke (1976: 94) mention it as a synonym of L. villosulum. This small species of $6 \mathrm{~mm}$ length is very close to $L$. villosulum, but is well separated by its barcode. We have examined the type and we can confirm that it differs from $L$. villosulum by the impunctate apical margin of the terga (Fig. 23D), as mentioned by Ebmer (1976: 251).

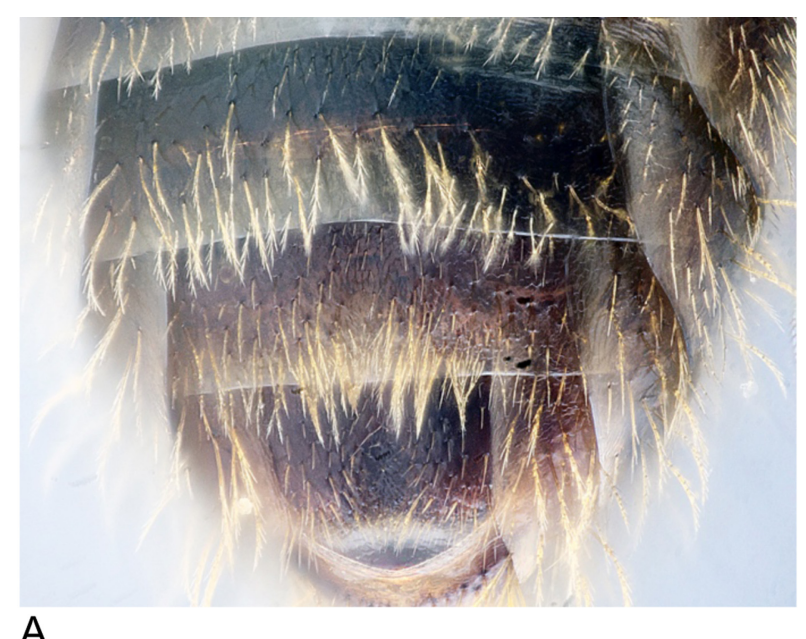

A

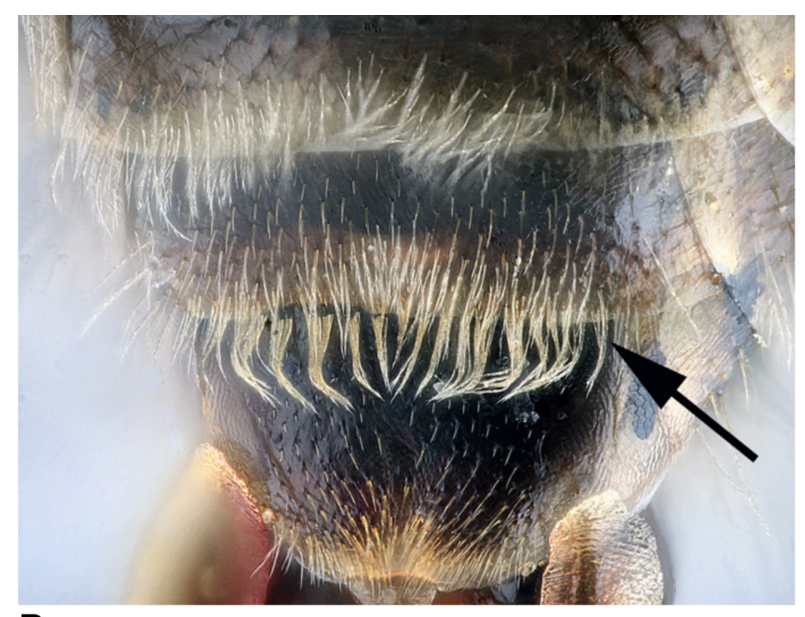

B

Fig. 21. Fringe on sternum 5 of males (arrow showing the fringe). A. Lasioglossum villosulum (Kirby, 1802). B. L. medinai (Vachal, 1895). 


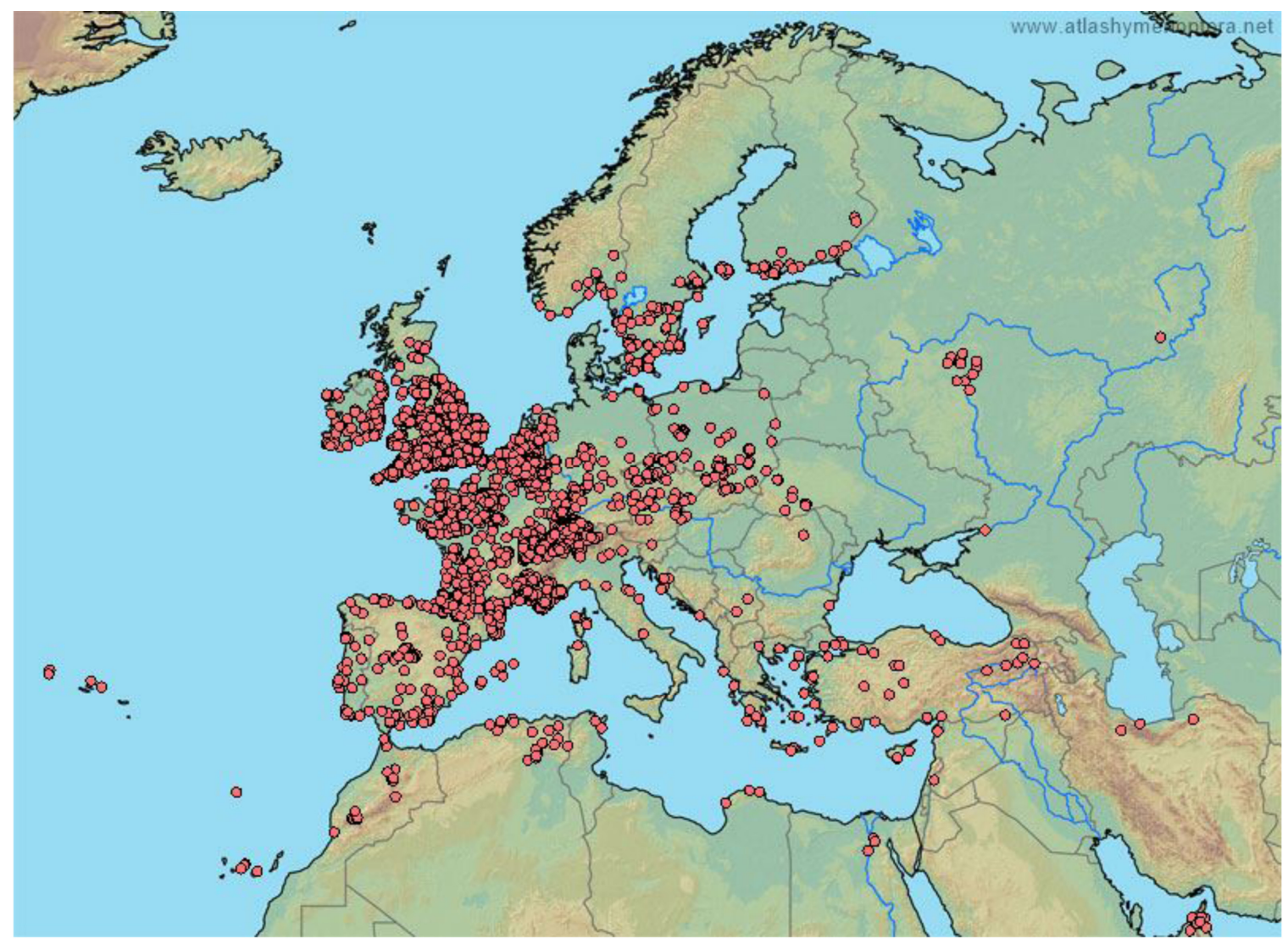

A

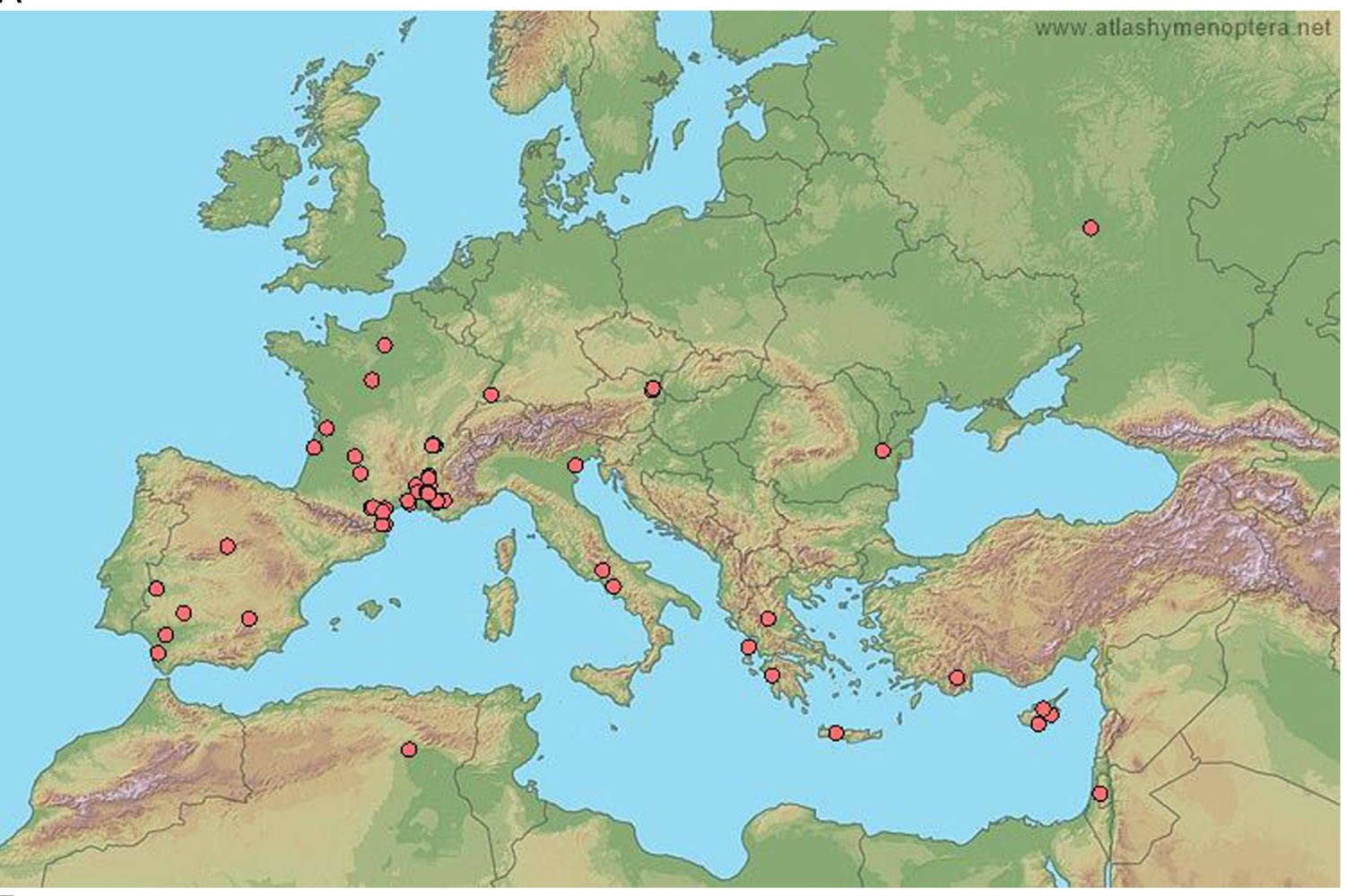

$\mathrm{B}$

Fig. 22. Geographical distribution of the two pseudocryptic species in the Western Palaearctic. A. Lasioglossum villosulum (Kirby, 1802). B. L. medinai (Vachal, 1895). 

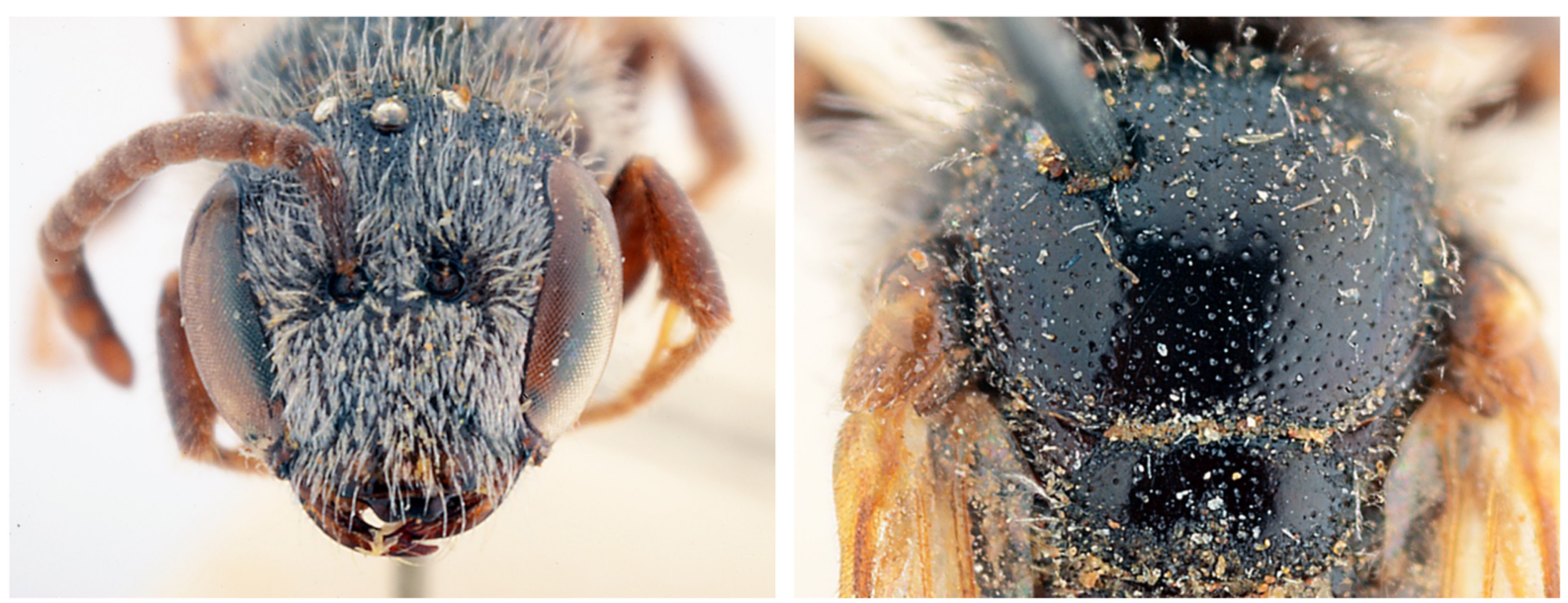

A

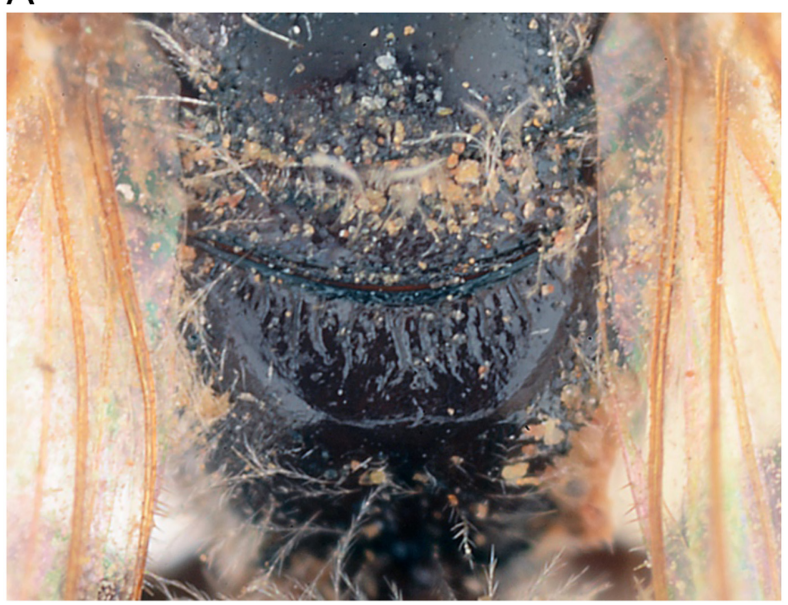

B

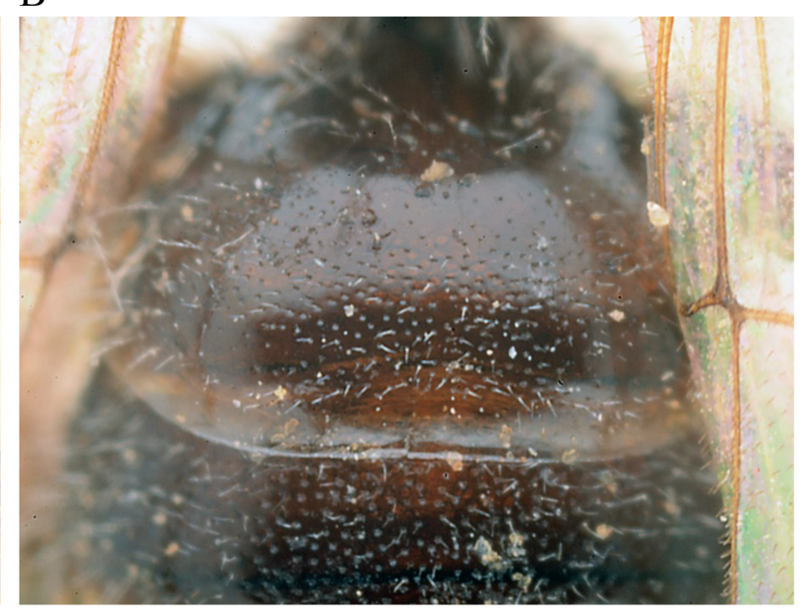

D

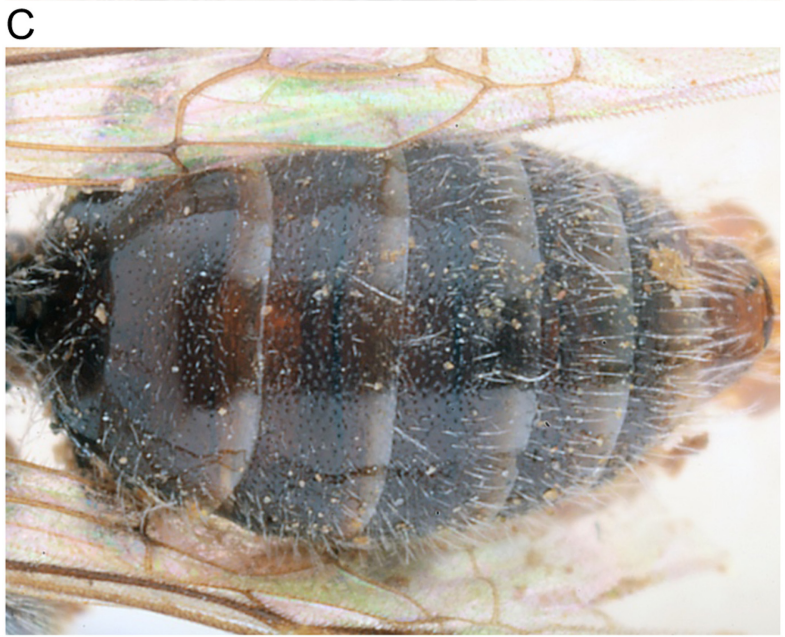

E

Fig. 23. Lasioglossum berberum (Benoist, 1941), holotype, đ̊. A. Head. B. Scutum. C. Propodeum. D. First tergum. E. Metasoma. 


\section{Discussion}

Morphological examination and DNA analyses allowed the discrimination of $L$. medinai and $L$. berberum from all specimens of $L$. villosulum studied here. Indeed, $L$. medinai females are generally larger than the L. villosulum ones but, as mentioned by Plateaux-Quénu et al. (1989), overwintering $L$. villosulum founders sometimes also are as large and are difficult to separate from those of $L$. medinai. The examination of fourteen females of $L$. medinai from a same breeding nest at Uchaux (Vaucluse) provided by Luc Plateaux, as well as the detailed examination of specimens from barcoded areas and from other localities (including DNA barcoded specimens), allowed the discovery of subtle morphological characters of punctuation to separate both species, as mentioned in the diagnosis above. Males identified as $L$. medinai by their larger size and denser punctuation of the scutum also show a stronger apical fringe on sternum 5, also some diagnostic and subtle differences in the genitalia as mentioned above (unfortunately the ventral membrane of the gonocoxite is often folded, which hinders the examination of its shape).

Our phylogenetics analyses and species delimitation methods consistently recognize L. medinai and L. berberum as distinct species from $L$. villosulum. The different lineages identified within $L$. villosulum either were recovered as a monophyletic group, sister to $L$. medinai and $L$. berberum (ultrametric BI, Fig. 4) or formed an unresolved polytomy (ML and BI trees, Fig. 3). They were not recovered as paraphyletic in relation to the clade of $L$. medinai and $L$. berberum in any analysis. Since no morphological characters were found to distinguish the different lineages of $L$. villosulum, we see no reason to further split this species.

Interestingly, the bPTP and GMYC species delimitation approaches suggests candidates species that are undistinguishable by morphology. This is the case for L. medinai and L. villosulum, which are split in different candidate cryptic species in the bPTP analysis and some GMYC analyses. These methods may oversplit the data (Luo et al. 2018; Pentinsaari et al. 2017) and may consider intraspecific lineages as candidate species. This could be the case for haplotypes XI and XVI (Table 3) whose specimens were collected in the Middle-East region (Turkey and Israel) and which are considered to form a distinct candidate species within L. medinai in all bPTP and the GMYC analyses suggesting $>6$ candidate species.

The clade of $L$. medinai included two sequences from GenBank labelled as L. villosulum (labels highlighted in red colour in Fig. S1A). These corresponded to one of the three Barcode Index Numbers (or BINs, Ratnasingham \& Hebert 2013) identified by Schmidt et al. (2015) for L. villosulum. A BIN is defined as a unique identifier for a sequence cluster and is obtained by an automatic structuring of DNA barcodes into possible species. Our new COI sequences of L. villosulum and L. medinai allow us to associate this BIN to L. medinai. We think that these sequences might come from specimens of $L$. medinai and which were not identified as such because $L$. medinai was probably considered as a synonym of $L$. villosulum when the specimens were identified. Five other BOLD records (identified as "Hymenoptera" or "Lasioglossum n. sp."), clustered with cluster A (Fig. S1) and may also belong to L. medinai. The same logic applies to the other non-morphologically identified specimens whose DNA barcodes are found in the other clusters (Fig. S1).

Additional specimens from the eastern Mediterranean and from Asia (including the subspecies arabicum and trichopse) combined with their floral preferences, as well as additional DNA markers, would be interesting to analyse. Such a complementary study would provide a better understanding of the systematics and population structure of the $L$. villosulum species complex that has such a wide geographical distribution. $L$. villosulum, L. medinai and L. berberum are sympatric but the first species is widespread throughout Europe, while the second one has a more Mediterranean or sub-Mediterranean distribution (Fig. 22) and the last one probably North-African distribution. 
Other cryptic or pseudocryptic species of Halictidae may be discovered in Europe in the future, thanks to molecular analyses. In this bee family, molecular analysis enables the identification of females of several species that are indistinguishable by morphology, whereas males generally have species-specific traits in genitalia (Pauly et al. 2015). Therefore, we advocate for developing a DNA library on a European scale, to obtain reliable identifications of halictid bee species.

\section{Acknowledgments}

We thank Mercedes Paris (MNCN) for the loan of the type of Halictus medinai Vachal, Patricia Peeters (SMF) for the loan of the type of H. hirtellus, Viola Richter (MNHUB) for the type of H. pauperatulellus, Corey Smith (AMNH) for the type of H. rufotegularis, Agnèle Touret-Alby (MNHN) for the types of $H$. villiersi and $H$. berberus, Holger Dathe (SDEI) for the types of Lasioglossum villosulum arabicum. We also thank Frederic Francis and Jeanine Bortels (GABT), Yael Mandelik and Gideon Pisanty (HUJ), Bernard Vaissière and Laurent Guilbaud (INRA), Hadjer Chichoune (University of Constantine, Algeria), Abdeljalil Louar (Algeria), David Genoud (Arzens, Aude, France), Olivier Durand (Beaupréauen-Mauges, Maine-et-Loire, France), Christophe Philippe (Cahors, Lot, France), Natasha de Manincor (ARSENIC project) and François Javier Ortiz-Sanchez (Almeria, Spain) for the loan of specimens. Luc Plateaux and Cécile Plateaux-Quénu have kindly provided us with specimens of both species from breeding nests, as well as copies of their publications on the subject. Professor Laurence Packer provided us with useful barcode sequences of $L$. villosulum. We thank Jason Gibbs and Laurence Packer, as well as a third anonymous referee, for all the comments to improve the manuscript.

Part of this research has been co-financed by the BELBEES project (Multidisciplinary assessment of BELgian wild BEE decline to adapt mitigation management policy; BELSPO - BR/132/A1/BELBEES). DNA analysis was carried out by the Joint Experimental Molecular Unit (JEMU), funded by the Belgian Science Policy.

\section{References}

Amiet F., Herrmann M., Müller A. \& Neumeyer R. 2001. Apidae 3. Halictus, Lasioglossum. Fauna Helvetica 3, Centre suisse de Cartographie de la Faune, Neuchâtel.

Azuma S. \& Kinjo M. 1987. Checklist of the Insects of Okinawa. Flora and fauna in Okinawa 1, University Ryukyus Nishihara, Okinawa.

Benoist R. 1941. Récoltes de R. Paulian et A. Villiers dans le Haut Atlas Marocain, 1938 (18. Note). Hyménoptères Apidés. Annales de la Société entomologique de France 110: 79-82.

Blüthgen P. 1920. Die deutschen Arten der Bienengattung Halictus Latr. (Hym.). Deutsche Entomologische Zeitschrift 1920: 81-302.

Blüthgen P. 1922. Beiträge zur Synonymie der Bienengattung Halictus Latr. Deutsche Entomologische Zeitschrift 1922: 46-66, 316-321.

Blüthgen P. 1923. Beiträge zur Synonymie der Bienengattung Halictus Latr. III. Deutsche Entomologische Zeitschrift 1923: 239-242.

Blüthgen P. 1926. Beiträge zur Kenntnis der indo-malayischen Halictus und Thrincostoma Arten (Hym. Apidae, Halictini). Zoologische Jahrbucher Jena (Systematik, Geographie und Biologie der Tiere) 51: 375-698.

Blüthgen P. 1928. Beiträge zur Kenntnis der indo-malayischen Halictus und Thrincostoma - Arten. 1 Nachtrag. Zoologische Jahrbucher Jena (Systematik, Geographie und Biologie der Tiere) 54: 343-406. 
Blüthgen P. 1930. Halictus Latr. In: Schmiedeknecht O. (ed.) Die Hymenopteren Nord- und Mitteleuropas: 729-767. Fischer Verlag, Jena.

Blüthgen P. 1933. Ein Beitrag zur Kenntnis der Bienenfauna Aegyptens (Hymenoptera: ApidaeHalictidae-Halictinae). Bulletin de la Société royale entomologique d'Egypte 1933 (1-3): 14-27.

Bossert S., Gereben-Krenn B.-A., Neumayer J., Schneller B. \& Krenn H.W. 2016. The cryptic Bombus lucorum complex (Hymenoptera: Apidae) in Austria: phylogeny, distribution, habitat usage and a climatic characterization based on COI sequence data. Zoological Studies 55 (13): 1-15. https://doi.org/10.6620/ZS.2016.55-13

Bouckaert R., Heled J., Kühnert D., Vaughan T., Wu C-H., Xie D., Suchard M.A., Rambaut A. \& Drummond A.J. 2014. BEAST 2: a software platform for Bayesian evolutionary analysis. PLoS Computational Biology 10 (4): e1003537. https://doi.org/10.1371/journal.pcbi.1003537

Bytinsky-Salz H. \& Ebmer A.W. 1974. The Halictidae of Israel (Hymenoptera, Apoidea). II. Genus Lasioglossum. Israel Journal of Entomology 9: 175-217.

Cockerell T.D.A. 1938a. Descriptions and Records of Bees - CLXVI. Annals and Magazine of Natural History Series 11.1 (1): 79-85. https://doi.org/10.1080/00222933808526744

Cockerell T.D.A 1938b. Halictine bees from Morocco. American Museum Novitates 997: 1-9.

Dalla Torre C.G. de 1896. Catalogus Hymenopterorum hucusque descriptorum systematicus et synonymicus. Vol X. Apidae (Anthophila). Engelmann, Leipzig.

Danforth B.N. 1999. Phylogeny of the bee genus Lasioglossum (Hymenoptera: Halictidae) based on mitochondrial COI sequence data. Systematic Entomology 24 (4): 377-393.

https://doi.org/10.1046/j.1365-3113.1999.00087.x

Danforth B.N. 2002. Evolution of sociality in a primitively eusocial lineage of bees. Proceedings of the National Academy of Sciences 99 (1): 286-290.

Dathe H.H. 2009. Order Hymenoptera, superfamily Apoidea. Families Colletidae, Andrenidae, Halictidae, Melittidae, Megachilidae and Apidae. Arthropod Fauna of the UAE 2: 335-432.

Ebmer A.W. 1974. Beiträge zur Kenntnis der Fauna Afghanistans. Halictus Latr. et Lasioglossum Curt., Halictidae, Apoidea, Hymenoptera. Časopis Moravského musea v Brně 59: 183-210.

Ebmer A.W. 1975. Die Typen und Typoide des Natur-Museum Senckenberg 54 Von Schenck beschriebene Halictidae (Ins.: Hymenoptera: Apoidea). Senckenbergiana Biologica 56: 233-246.

Ebmer A.W. 1976. Halictus and Lasioglossum aus Marokko. Linzer biologische Beiträge 8 (1): 205-288.

Ebmer A.W. 1978a. Die Halictidae der Mandschurei (Apoidea, Hymenoptera). Bonner Zoologische Beiträge 29: 183-221.

Ebmer A.W. 1978b. Die Bienen der Gattungen Halictus Latr., Lasioglossum Curt. und Dufourea Lep. (Hymenoptera, Halictidae) aus Korea. Annales Historico-Naturales Musei Nationalis Hungarici 70: 307-319.

Ebmer A.W. 1978c. Halictus, Lasioglossum, Rophites und Systropha aus dem Iran. Linzer biologische Beiträge 10: 1-109.

Ebmer A.W. 1982. Zur Bienenfauna der Mongolei. Die Arten der Gattungen Halictus Latr. und Lasioglossum Curt. (Hymenoptera: Halictidae). Ergebnisse der Mongolisch-Deutschen Biologischen Expedition seit 1962, Nr 108. Mitteilungen aus dem Zoologischen Museum in Berlin 58(2): 199-227. 
Ebmer A.W. 1988. Kritische Liste der nicht-parasitischen Halictidae Österreichs mit Berücksichtigung aller mitteleuropaïschen Arten (Insecta: Hymenoptera: Apoidea: Halictidae). Linzer biologische Beiträge 20 (2): 527-711.

Ebmer A.W. 1996. Asiatische Halictidae, 5. Daten zur Aculeaten-Fauna der Ussuri-Region unter Berücksichtigung der angrenzenden Gebiete (Insecta: Hymenoptera: Apoidea: Halictidae: Halictinae). Linzer biologische Beiträge 28 (1): 261-304.

Ebmer A.W. 2004. Zur Bienenfauna Nepals: Arten der Gattungen Halictus, Lasioglossum und Dufourea (Insecta: Hymenoptera: Apoidea: Halictidae). Veröffentichungen Naturmuseum Erfurt 23: 123-150.

Ebmer A.W. 2005. Zur Bienenfauna der Mongolei. Die Arten der Gattungen Halictus Latr. und Lasioglossum Curt. (Insecta: Hymenoptera: Apoidea: Halictidae: Halictinae), Ergänzungen und Korrekturen. Linzer biologische Beiträge 37 (1): 343-392.

Ebmer A.W. 2006. Daten zur Aculeaten-Fauna der Ussuri-Region unter Berücksichtigung der angrenzenden Gebiete - 2 Arten der Gattungen Halictus, Lasioglossum, Dufourea, Macropis aus dem Lazovski Zapovednik - Naturrervat Laso (Insecta: Hymenoptera: Apoidea: Halictidae, Melittidae). Linzer biologische Beiträge 38 (1): 541-593.

Ebmer A.W. 2008. Neue Taxa der Gattungen Halictus Latreille 1804 und Lasioglossum Curtis 1833 (Hymenoptera, Apoidea, Halictidae) aus den Vereinigten Arabischen Emiraten. Linzer biologische Beiträge 40 (1): 551-580.

Ezard T., Fujisawa T. \& Barraclough T.G. 2017. splits: SPecies'LImits by Threshold Statistics. R package version 1.0-19/r52. Available from https://R-Forge.R-project.org/projects/splits/ [accessed 8 Jun. 2019].

Fellendorf M., Mohra C., Roberts S., Wirtz P. \& van der Zanden G. 1999. The bees of Madeira (Hymenoptera, Apoidea). Bocagiana, Museu Municipal do Funchal (Historia Natural) 197: 1-17.

Ferrari R.R. 2019. A revision of Colletes Latreille (Hymenoptera: Colletidae: Colletinae) from Brazil, Paraguay and Uruguay. Zootaxa 4606 (1): 1-91. https://doi.org/10.11646/zootaxa.4606.1.1

Folmer O., Black M., Hoe W., Lutz R. \& Vrijenhoek R. 1994. DNA primers for amplification of mitochondrial cytochrome c oxidase subunit I from diverse metazoan invertebrates. Molecular Marine Biology and Biotechnology 3 (5): 294-299.

Françoso E. \& Arias M.C. 2013. Cytochrome c oxidase I primers for corbiculate bees: DNA barcode and mini-barcode. Molecular Ecology 13: 844-850. https://doi.org/10.1111/1755-0998.12135

Fujisawa T. \& Barraclough T.G. 2013. Delimiting species using single-locus data and the Generalized Mixed Yule Coalescent approach: a revised method and evaluation on simulated data sets. Systematic Biology 62: 707-724. https://doi.org/10.1093/sysbio/syt033

Gibbs J. 2018. DNA barcoding a nightmare taxon: assessing barcode index numbers and barcode gaps for sweat bees. Genome 61 (1): 21-31. https://doi.org/10.1139/gen-2017-0096

Gibbs J., Brady S.G., Kanda K. \& Danforth B.N. 2012. Phylogeny of halictine bees supports a shared origin of eusociality for Halictus and Lasioglossum (Apoidea: Anthophila: Halictidae). Molecular Phylogenetics and Evolution 65 (3): 926-939. https://doi.org/10.1016/j.ympev.2012.08.013

Gibbs J., Packer L., Dumesh S. \& Danforth B. 2013. Revision and reclassification of Lasioglossum (Evylaeus), L. (Hemihalictus) and L. (Sphecodogastra) in Eastern North America (Hymenoptera, Apoidea, Halictidae). Zootaxa 3672: 1-117. https://doi.org/10.11646/zootaxa.3672.1.1

Goaga A. 2003. Contributii la studiul specilior de Halictide (Apoidea: Halictidae) din Fauna Moldavei. Complexul Muzeal de Ştiinţele Naturii "Ion Borcea” Bacău, Studii şi Comunicări 2000-2003: 181-195.

Gogala A. 1999. Bee fauna of Slovenia: checklist of species (Hymenoptera Apoidea). Scopolia 42: 1-79. 
Gonzáles-Vaquero R.A. \& Roig-AlsinaA. 2019. The bee Ruizanthedella mutabilis Spinola (Hymenoptera: Halictidae): a very common but poorly known species studied using integrative taxonomy. Zootaxa 4563 (1): 191-200. https://doi.org/10.11646/zootaxa.4563.1.12

González-Vaquero R.A., Roig-Alsina A. \& Packer L. 2016. DNA barcoding as a useful tool in the systematic study of wild bees of the tribe Augochlorini (Hymenoptera: Halictidae). Genome 59: 889898. https://doi.org/10.1139/gen-2016-0006

Haneda Y. 1990. [On the Apoidea (Hymenoptera) of Fukui Prefecture, Japan (4)]. Entomological Journal of Fukui 7: 2-10. [In Japanese.]

Hebert P.D.N., Ratnasingham S., Zakharov E.V., Telfer A.C., Levesque-Beaudin V., Milton M.A., Pedersen S., Jannetta P. \& de Waard J.R. 2016. Counting animal species with DNA barcodes: Canadian insects. Philosophical Transactions of the Royal Society of London B 371: 20150333. https://doi.org/10.1098/rstb.2015.0333

Hillis D. \& Bull J.J. 1993. An empirical test of bootstrapping as a method for assessing confidence in phylogenetic analysis. Systematic Biology 42 (2): 182-192.

Huelsenbeck J.P. \& Rannala B. 2004. Frequentist properties of Bayesian posterior probabilities of phylogenetic trees under simple and complex substitution models. Systematic Biology 53 (6): 904-913.

Kirby W. 1802. Monographia Apum Angliae. Vols 1-2. Privately published, Ipswich.

Kress W.J., Garcia-Robledo C., Uriarte M. \& Erickson D.L. 2015. DNA barcodes for ecology, evolution, and conservation. Trends in Ecology \& Evolution 30 (1): 25-35.

https://doi.org/10.1016/j.tree.2014.10.008

Kumar S., Stecher G. \& Tamura K. 2016. MEGA7: Molecular Evolutionary Genetics Analysis Version 7.0 for Bigger Datasets. Molecular Evolutionary Genetics Analysis 33 (7): 1870-1874.

https://doi.org/10.1093/molbev/msw054

Lajus D., Sukhikh N. \& Alekseev V. 2015. Cryptic or pseudocryptic: can morphological methods inform copepod taxonomy? An analysis of publications and a case study of the Eurytemora affinis species complex. Ecology and Evolution 5 (12): 2374-2385. https://doi.org/10.1002/ece3.1521

Landaverde-González P., Moo-Valle H., Murray T.E., Paxton R.J., Quezada-Euan J.J.G. \& Husemann M. 2017. Sympatric lineage divergence in cryptic Neotropical sweat bees (Hymenoptera: Halictidae: Lasioglossum). Organisms Diversity \& Evolution 17: 251-265.

https://doi.org/10.1007/s13127-016-0307-1

Lanfear R., Calcott B., Ho S.Y. \& Guindon S. 2012. PartitionFinder: combined selection of partitioning schemes and substitution models for phylogenetic analyses. Molecular Biology and Evolution 29 (6): 1695-1701. https://doi.org/10.1093/molbev/mss020

Lanfear R., Frandsen P.B., Wright A.M., Senfeld T. \& Calcott B. 2017. PartitionFinder 2: new methods for selecting partitioned models of evolution for molecular and morphological phylogenetic analyses. Molecular Biology and Evolution 34 (3): 772-773. https://doi.org/10.1093/molbev/msw260

Larkin M.A., Blackshields G., Brown N.P., Chenna R., McGerrigan P.A., McWilliam H., Valentin F., Wallace I.M., Wilm A., Lopez R., Thomson J.D., Gibson T.J. \& Higgins D.G. 2007. Clustal W and Clustal X version 2.0. Bioinformatics 23 (1): 2947-2948. https://doi.org/10.1093/bioinformatics/btm404

Levchenko T.V. 2015. Contributions to the fauna of bees (Hymenoptera: Apoidea) of Moscow Province. 5. Family Halictidae. Genera Lasioglossum Curtis, 1833 and Evylaeus Robertson, 1902. Eversmannia 43-44: 20-43. 
Luo A., Ling C., Ho S.Y.W \& Zhu C.D. 2018. Comparison of methods for molecular species delimitation across a range of speciation scenarios. Systematic Biology 67: 830-846.

https://doi.org/10.1093/sysbio/syy011

Magnacca K.N. \& Brown M.J. 2012. Barcoding a regional fauna: Irish solitary bees. Molecular Ecology Research 12: 990-998. https://doi.org/10.1111/1755-0998.12001

Michonneau F. 2016. Using GMYC for Species Delination.

Available from https://zenodo.org/record/838260\#.XPuNfi-B3Vo [accessed 25 March 2019].

Michonneau F., Bolker B., Holder M., Lewis P. \& O’Meara B. 2018. rncl: An Interface to the Nexus Class Library. $R$ package version 0.8.3. Available from https://CRAN.R-project.org/package=rncl [accessed 8 Jun. 2019].

Murao R. 2017. Bees of the Hemihalictus series of Lasioglossum Curtis (Hymenoptera, Halictidae) in South Korea. Zootaxa 4268 (4): 451-488. https://doi.org/10.11646/zootaxa.4268.4.1

Natural History Museum. 2014. Dataset: Collection specimens. Resource: Specimens. Natural History Museum Data Portal. https://doi.org/10.5519/0002965 [accessed 25 Nov. 2018].

Ortiz-Sánchez F.J. \& Pauly A. 2017. Contribution à la connaissance des Halictinae d'Espagne, avec un atlas des espèces de la Péninsule Ibérique (Hymenoptera: Apoidea: Halictidae). Belgian Journal of Entomology 54: 1-92.

Packer L., Porsa A., Plateaux-Quénu C. \& Plateaux L. 1999. A cryptic species allied to Evylaeus villosulus (Kirby) (Hymenoptera: Halictidae). Annales de la Société entomologique de France (N.S.) 35 (2): $165-171$.

Padial J.M., Miralles A., De la Riva I. \& Vences M. 2010. The integrative future of taxonomy. Frontiers in Zoology 7 (1): 1-14. https://doi.org/10.1186/1742-9994-7-16

Paradis E. 2010. Pegas: an R package for population genetics with an integrated-modular approach. Bioinformatics 26: 419-420.

Paradis E. \& Schliep K. 2018. Ape 5.0: an environment for modern phylogenetics and evolutionary analyses in R. Bioinformatics 35 (1): 526-528. https://doi.org/10.1093/bioinformatics/bty633

Pauly A. \& Belval S. 2017. Atlas des Halictidae de France (Hymenoptera: Apoidea). Belgian Journal of Entomology 53: 1-34.

Pauly A., Devalez J., Sonet G., Nagy Z.T. \& Boevé J.-L. 2015. DNA barcoding and male genital morphology reveal five new cryptic species in the West Palaearctic bee Seladonia smaragdula (Vachal, 1895) (Hymenoptera: Apoidea: Halictidae). Zootaxa 4034 (2): 257-290.

https://doi.org/10.11646/zootaxa.4034.2.2

Pentinsaari M., Vos R. \& Mutanen M. 2017. Algorithmic single-locus species delimitation: effects of sampling effort, variation and nonmonophyly in four methods and 1870 species of beetles. Molecular Ecology Resources 17: 393-404. https://doi.org/10.1111/1755-0998.12557

Pesenko Y.A. 2007a. Subgeneric classification of the Palaearctic bees of the genus Evylaeus Robertson (Hymenoptera: Halictidae). Zootaxa 1500: 1-54.

Pesenko Y.A. 2007b. A taxonomic study of the bee genus Evylaeus Robertson of Eastern Siberia and the Far East of Russia (Hymenoptera: Halictidae). Zoosystematica Rossica 16: 79-123.

Pesenko Y., Banaszak J., Radchenko V. \& Cierzniak T., 2000. Bees of the Family Halictidae (excluding Sphecodes) of Poland: Taxonomy, Ecology, Bionomics. University Publishers of the Pedagogical School, Bydgoszcz, Poland. 
Plateaux-Quénu C. 1993. Modalités de la socialisation chez les Halictinae (Hymenoptera, Halictidae). I. Biologie des Halictinae. Année biologique 32 (4): 183-204.

Plateaux-Quénu C. \& Plateaux L. 1981. La variation individuelle d'Evylaeus villosulus (K.), espèce solitaire (Hym. Halictinae). I. Fondatrices de printemps. Annales des Sciences naturelles, Zoologie 13e Série 3: 249-258.

Plateaux-Quénu C. \& Plateaux L. 1985. La variation individuelle d'Evylaeus villosulus (K.), espèce solitaire (Hym., Halictinae). Comparaison des fondatrices de printemps et de leurs filles, appartenant à la première génération. Actes des Colloques Insectes sociaux 2: 293-302.

Plateaux-Quénu C. \& Plateaux L. 1986. Alternance de générations chez Evylaeus villosulus (K.) (Hym. Halictinae). Actes Colloques internationaux U.I.E.I.S., section française 1985 3: 73-82.

Plateaux-Quénu C. \& Plateaux L. 1987. Présence de fondatrices géantes dans deux populations d'Evylaeus villosulus (K.) (Hym., Halictinae). Annales des Sciences naturelles, Zoologie $13^{\mathrm{e}}$ série, 1986-1987 8: 259-266.

Plateaux-Quénu C. \& Plateaux L. 1993. Dimorphisme des femelles dans une population d'Evylaeus villosulus (Kirby) (Hym., Halictinae). Bulletin de la Société zoologique de France 118 (4): 387-393.

Plateaux-Quénu C., Plateaux L. \& Packer L. 1987. Preadaptations to sociality in the solitary, bivoltine Halictine bee Evylaeus villosulus (K.). Evolution of Insects Societies. Chemistry and Biology of Social Insects. J. Peperny, Munich.

Plateaux-Quénu C., Plateaux L. \& Packer L. 1989. Biological notes on Evylaeus villosulus (K.) (Hymenoptera, Halictidae), a bivoltine, largely solitary halictine bee. Insectes sociaux, Paris 36 (4): 245-263.

Pridal A. 2004. Checklist of the bees in the Czech Republic and Slovakia with comments on their distribution and taxonomy (Insecta: Hymenoptera: Apoidea). Acta Universitatis Agriculturae et Silviculturae Mendelianae Brunensis 52: 29-65.

Pons J., Barraclough T.G., Gomez-Zurita J., Cardoso A., Duran D.P., Hazell S., Kamoun S., Sumlin W.D. \& Vogler A.P. 2006. Sequence-based species delimitation for the DNA taxonomy of undescribed insects. Systematic Biology 55: 1-15. https://doi.org/10.1080/10635150600852011

Praz C., Müller A. \& Genoud D. 2019. Hidden diversity in European bees: Andrena amieti sp. n., a new Alpine bee species related to Andrena bicolor (Fabricius, 1775) (Hymenoptera, Apoidea, Andrenidae). Alpine Entomology 3: 11-38. https://doi.org/10.3897/alpento.3.29675

Rambaut A. 2017. Figtree 1.4.0. Available from http://tree.bio.ed.ac.uk/software/figtree/ [accessed 18 Aug. 2017].

Rambaut A., Drummond A.J., Xie D., Baele G. \& Suchard M.A. 2018. Posterior summarisation in Bayesian phylogenetics using Tracer 1.7. Systematic Biology 67: 901-904.

https://doi.org/10.1093/sysbio/syy032

Rasmussen C., Schmidt H.T. \& Madsen H.B. 2016. Distribution, phenology and host plants of Danish bees (Hymenoptera, Apoidea). Zootaxa 4212 (1): 1-100. https://doi.org/10.11646/zootaxa.4212.1.1

Ratnasingham S. \& Hebert P.D.N. 2013. A DNA-based registry for all animal species: the Barcode Index Number (BIN) system. PLoS ONE 8 (7): e66213. https://doi.org/10.1371/journal.pone.0066213

Ronquist F., Teslenko M., van der Mark P., Darling A., Larget B., Liu L., Suchard M.A. \& Huelsenbeck J.P. 2012. MrBayes 3.2: Efficient Bayesian phylogenetic inference and model choice across a large model space. Systematic Biology 61 (3): 539-542. https://doi.org/10.1093/sysbio/sys029 
Schenck A. 1869. Beschreibung der nassauischen Bienen. II. Nachtrag. Jahrbücher des Nassauischen Vereins für Naturkunde 21-22 (1867-1868): 301-312 (Halictus), 375 (Nachträge).

Schmidt S., Schmid-Egger C., Morinière J., Haszprunar G. \& Hebert P.D.N. 2015. DNA barcoding largely supports 250 years of classical taxonomy: identifications for Central European bees (Hymenoptera, Apoidea partim). Molecular Ecology Resources 15 (4): 985-1000.

https://doi.org/10.1111/1755-0998.12363

Simon C., Frati F., Beckenbach A., Crespi B., Hong Liu \& Flook P. 1994. Evolution, weighting, and phylogenetic utility of mitochondrial gene sequences and a compilation of conserved polymerase chain reaction primers. Annals of the Entomological Society of America 87 (6): 651-701.

Strand E. 1909. Die paläarktischen Halictus-Arten des Kgl. Zoologischen Museums zu Berlin, z.T. nach Bestimmungen von J. D. Alfken. Archiv für Naturgeschichte 75 I (1): 1-62.

Strand E. 1914. H. Sauter Formosa Ausbeute: Apidae II (Die Halictus-Arten von Formosa). Archiv für Naturgeschichte A 12 (1913): 147-171.

Struck T.H., Feder J.L., Bendiksby M., Birkeland S., Cerca J., Gusarov V.I., Kistenich S., Larrson K.- H., Lee Hsiang Liow, Nowak M.D., Stedje B., Bachmann L. \& Dimitrov D. 2017. Finding evolutionary processes hidden in cryptic species. Trends in Ecology \& Evolution: 1-11.

https://doi.org/10.1016/j.tree.2017.11.007

Sukumaran J. \& Holder M.T. 2010. DendroPy: a Python library for phylogenetic computing. Bioinformatics 26: 1569-1571. https://doi.org/10.1093/bioinformatics/btq228

Sukumaran J. \& Holder M.T. 2017. SumTrees: Phylogenetic Tree Summarization. Ver. 4.3.0. Available from https://github.com/jeetsukumaran/DendroPy [accessed 16 Feb 2018].

Svensson B.G., Erlandsson S. \& Janzon L.-A. 1990. Catalogus Insectorum Sueciae. Hymenoptera, Apoidea. 2. Andrenidae and Halictidae. Entomologisk Tidskrift 111: 47-52.

Takahashi H. \& Sakagami S.F. 1993. Notes on the halictine bees (Hymenoptera Apoidea) of the Izu Islands: Lasioglossum kuroshio sp. nov., life cycles in Hachijo-jima Is., and a preliminary list of the species in the Izu Islands. Japanese Journal of Entomology 61 (2): 267-278.

Tang C.Q., Humphreys A.M., Fontaneto D., Barraclough T.G. 2014. Effects of phylogenetic reconstruction method on the robustness of species delimitation using single-locus data. Methods in Ecology and Evolution 5 (10): 1086-1094. https://doi.org/10.1111/2041-210X.12246

Tang C.Q., Notton D.G., Norman H. \& Vogler A. 2018. Taxonomic Fellowship to Support the National Pollinators Strategy - EVID4 Evidence Project Final Report. Department for Environment, Food and Rural Affairs and The Natural History Museum, London.

Usui M., Nishijuma Y., Fukuda H. \& Sakagami S.F. 1976. A wild bee survey in Obihiro, eastern Hokkaido. Research Bulletin of Obihiro University 10: 225-251.

Vachal J. 1895. Halictus nouveaux de la collection Medina. Anales de la Sociedad Española de Historia Natural 24: 147-150.

Warncke K. 1973. Zur Systematik und Synonymie der mitteleuropäischen Furchenbienen Halictus Latreille (Hymenoptera, Apoidea, Halictidae). Bulletin de la Société royale des Sciences de Liège 42 (7-8): 277-295.

Warncke K. 1975a. Beitrag zur Systematik und Verbreitung der Furchenbienen in der Türkei (Hymenoptera, Apoidea, Halictus). Polskie Pismo Entomologiczne 45: 81-128.

Warncke K. 1975b. Zur Kenntnis der Bienengattung Halictus Latr. auf den Kanarischen Inseln (Hym., Apoidea). Vieraea 4: 201-223. 
Warncke K. 1976. Bemerkungen zu der Arbeit von Ebmer über die als Apis beschriebenen Bienen der Gattung Halictus und ein Beitrag zur Namensklärung nordafrikanischer Bienen der gleichen Gattung (Hym. Apidae). Nachrichtenblatt der Bayerischen Entomologen 25 (5): 89-96.

Weissmann J.A., Picanço A., Borges P.A.V. \& Schaefer H. 2017. Bees of the Azores: an annotated checklist (Apidae, Hymenoptera). Zookeys 642: 63-95. https://doi.org/10.3897/zookeys.642.10773

Wilcox T.P., Zwickl D.J., Heath T.A. \& Hillis D.M. 2002. Phylogenetic relationships of the dwarf boas and a comparison of Bayesian and bootstrap measures of phylogenetic support. Molecular Phylogenetics and Evolution 25: 361-371. https://doi.org/10.1016/S1055-7903(02)00244-0

Zhang J., Kapli P., Pavlidis P. \& Stamatakis A. 2013. A general species delimitation method with applications to phylogenetic placements. Bioinformatics 29 (22): 2869-2876.

https://doi.org/10.1093/bioinformatics/btt499

Zwickl D.J. 2006. Genetic Algorithm Approaches for the Phylogenetic Analysis of Large Biological Sequence Datasets under the Maximum Likelihood Criterion. Ph.D. dissertation, The University of Texas at Austin. Available from http://hdl.handle.net/2152/2666 [accessed 4 Jul. 2019].

Manuscript received: 9 April 2018

Manuscript accepted: 28 June 2019

Published on: 1 August 2019

Topic editor: Gavin Broad

Desk editor: Kristiaan Hoedemakers

Printed versions of all papers are also deposited in the libraries of the institutes that are members of the EJT consortium: Muséum national d'Histoire naturelle, Paris, France; Meise Botanic Garden, Belgium; Royal Museum for Central Africa, Tervuren, Belgium; Royal Belgian Institute of Natural Sciences, Brussels, Belgium; Natural History Museum of Denmark, Copenhagen, Denmark; Naturalis Biodiversity Center, Leiden, the Netherlands; Museo Nacional de Ciencias Naturales-CSIC, Madrid, Spain; Real Jardín Botánico de Madrid CSIC, Spain; Zoological Research Museum Alexander Koenig, Bonn, Germany; National Museum, Prague, Czech Republic. 